\title{
Biosecurity Plan for Palmyra Atoll
}
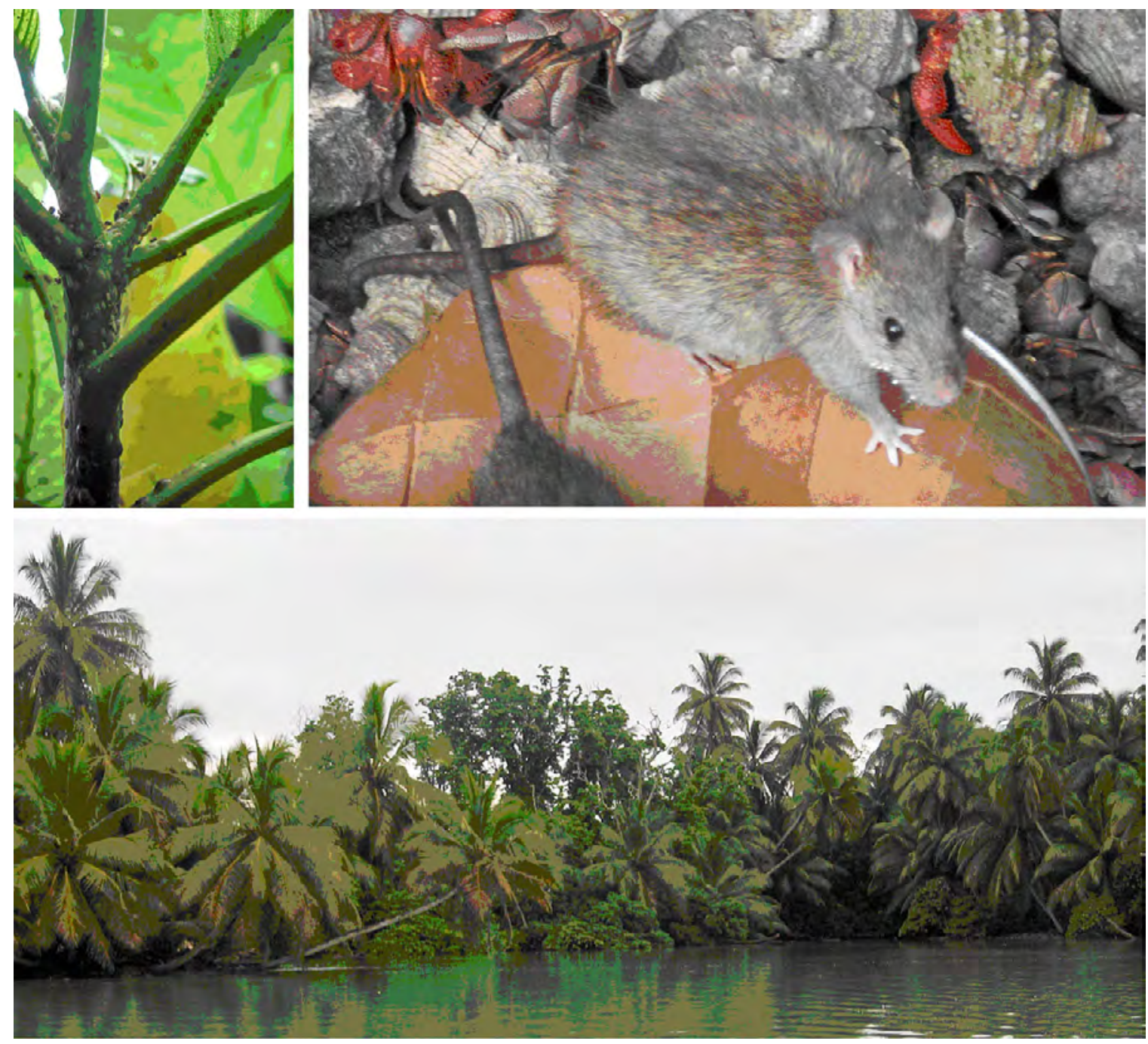

\section{Open-File Report 2010-1097}


Cover: Images showing ants, scale, black rats, and coconut trees found at Palmyra Atoll.

(Photographs by Stacie Hathaway, U.S. Geological Survey, 2008.) 


\section{Biosecurity Plan for Palmyra Atoll}

By Stacie A. Hathaway and Robert N. Fisher

Prepared for The Nature Conservancy Palmyra Program

Open-File Report 2010-1097

U.S. Department of the Interior

U.S. Geological Survey 


\section{U.S. Department of the Interior \\ KEN SALAZAR, Secretary}

\section{U.S. Geological Survey \\ Marcia K. McNutt, Director}

U.S. Geological Survey, Reston, Virginia: 2010

For more information on the USGS-the Federal source for science about the Earth, its natural and living resources, natural hazards, and the environment, visit $h t t p: / / w w w . u s g s . g o v$ or call 1-888-ASK-USGS.

For an overview of USGS information products, including maps, imagery, and publications, visit http://www.usgs.gov/pubprod

To order this and other USGS information products, visit http://store.usgs.gov

Suggested citation:

Hathaway, S.A., and Fisher, R.N., 2010, Biosecurity plan for Palmyra Atoll: U.S. Geological Survey Open-File Report 2010-1097, 80 p.

Any use of trade, product, or firm names is for descriptive purposes only and does not imply endorsement by the U.S. Government.

Although this report is in the public domain, permission must be secured from the individual copyright owners to reproduce any copyrighted material contained within this report. 


\section{Contents}

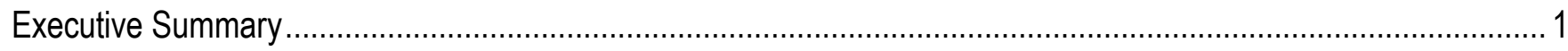

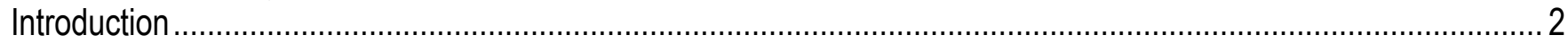

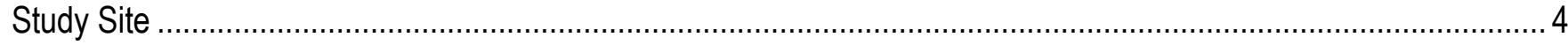

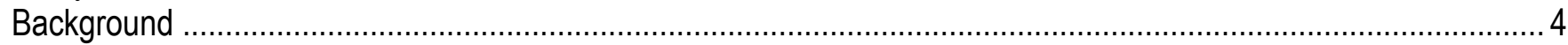

Terrestrial Non-Native or Invasive Species at Palmyra Atoll ...................................................................... 5

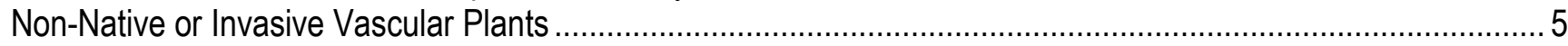

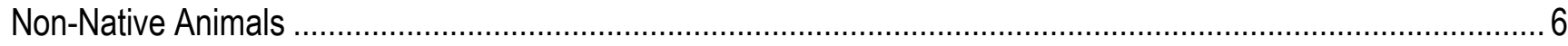

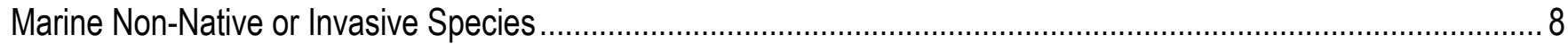

Existing Non-Native Species Laws, Policies, Protocols ..............................................................................

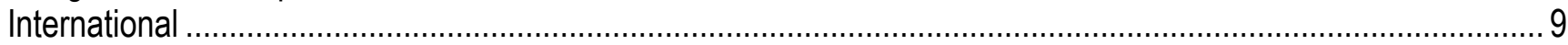

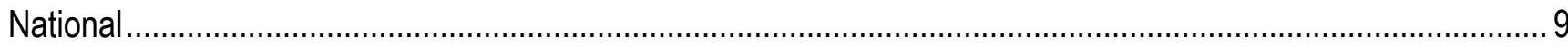

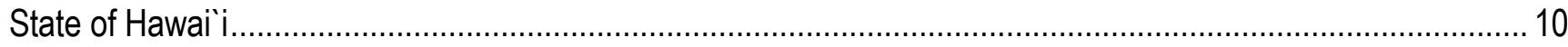

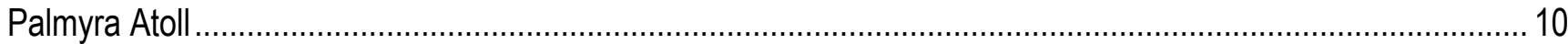

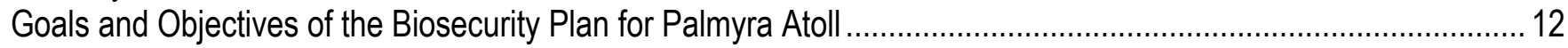

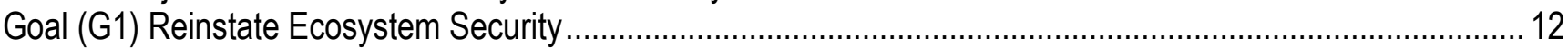

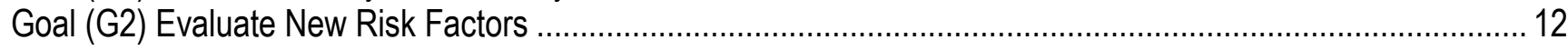

Scope and Limitations of this Biosecurity Plan.................................................................................... 12

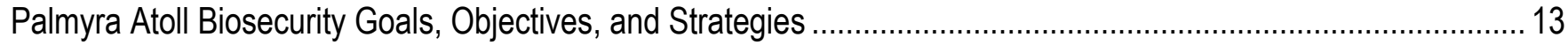

Goal (G1) Reinstate Ecosystem Security ............................................................................................. 13

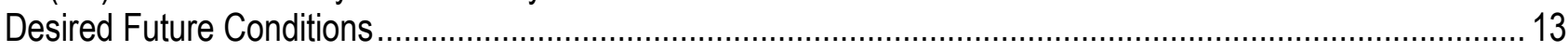

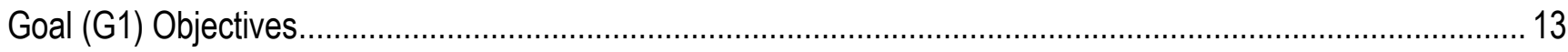

(G1-01) Prevention ……………………………… 13

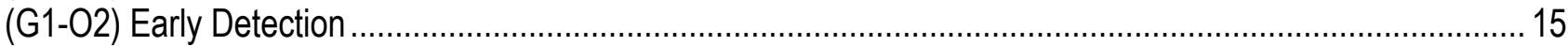

(G1-03) Eradicate Incipient Invasive Species ..................................................................................... 17

(G1-04) Eradicate or Control the Spread of Established Non-Native and (or) Invasive Species...................... 18

(G1-05) Support, Promote, and Coordinate Research and Monitoring that Increases the Understanding of Non-Native and Invasive Species at Palmyra Atoll and Improves Non-Native Species Management Decision

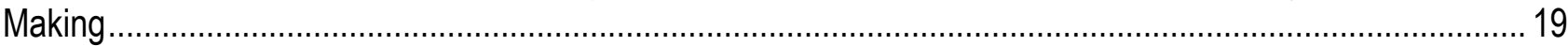

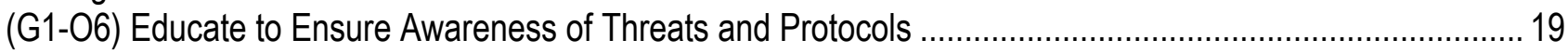

Goal (G2) Monitor New Risk Factors_-Develop Ongoing Assessment............................................................ 20

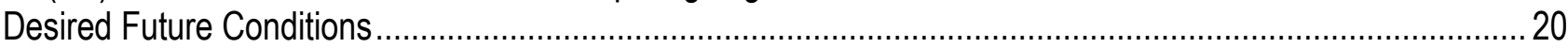

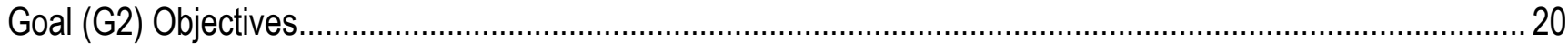

(G2-01) Adaptive Management Audit and Review............................................................................. 20

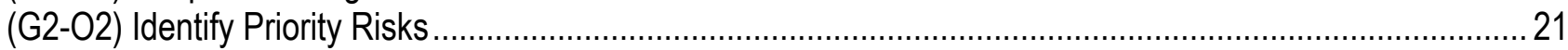

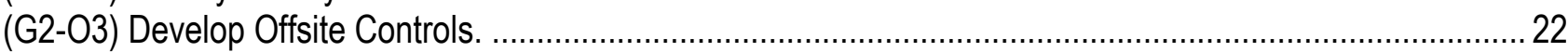

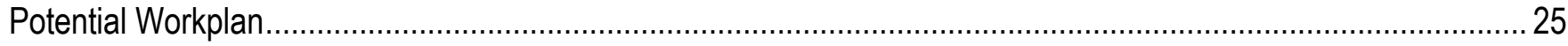

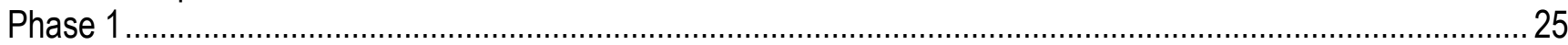

Phase 2

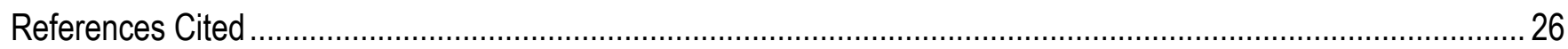

Appendix 1. Potential Non-Native Species Introduction Pathways Relevant to Palmyra Atoll .................................4 4

Appendix 2. Special Conditions and Rules for Visiting and Departing Palmyra Atoll and Moving Intra-Atoll .............42

Appendix 3. Additional Special Conditions for Food Provisions Destined for Palmyra Atoll.....................................46

Appendix 4. Conditions and Rules for Air Transport to Palmyra Atoll ................................................................ 47 


\section{Contents-Continued}

Appendix 5. Conditions and Rules for Shipping Vessels, Containers, and Other Cargo Destined for Palmyra Atoll.

Appendix 6. Disinfection Standards for Used Vehicle, Machinery, and Equipment Destined for Palmyra Atoll .........54

Appendix 7. Disinfection Protocol for Boats and Trailers Destined for Palmyra Atoll

Appendix 8. Hawai i Department of Land and Natural Resources, Adoption of Chapter 13-76, Hawai i

Administrative Rules, "Non-Indigenous Aquatic Species"

Appendix 9. Disinfection of Scientific/Recreational Equipment, Dive Gear, and Subsistence or Other

Fishing Gear for Prevention of Disease and Introduced Species

Appendix 10. Draft of Communications Strategy Components for Awareness of Non-Native/Invasive Species at Palmyra Atoll

Figure

Figure 1. Map of Palmyra Atoll

\section{Tables}

Table 1. Experts consulted regarding Palmyra Atoll management planning.

Table 2. Terrestrial non-native or invasive plant species identified at Palmyra Atoll. 32

Table 3. Terrestrial non-native vertebrate species identified at Palmyra Atoll.

Table 4. Terrestrial native and non-native invertebrate species identified at Palmyra Atoll. 36

Table 5. Marine non-native or invasive species. 


\section{Conversion Factors}

Conversion Factors

\begin{tabular}{|c|c|c|}
\hline Multiply & By & To obtain \\
\hline \multicolumn{3}{|c|}{ Length } \\
\hline meter $(\mathrm{m})$ & 3.281 & foot $(\mathrm{ft})$ \\
\hline kilometer (km) & 0.6214 & mile (mi) \\
\hline millimeter $(\mathrm{mm})$ & 0.03937 & inch (in.) \\
\hline \multicolumn{3}{|c|}{ Area } \\
\hline square kilometer $\left(\mathrm{km}^{2}\right)$ & 0.3861 & square mile $\left(\mathrm{mi}^{2}\right)$ \\
\hline \multicolumn{3}{|c|}{ Volume } \\
\hline liter (L) & 33.82 & ounce, fluid (fl. oz) \\
\hline liter (L) & 0.264 & gallons (gal) \\
\hline milliliter (ml) & 0.0338 & ounce, fluid (fl. oz) \\
\hline milliliter $(\mathrm{ml})$ & 0.000264 & gallons (gal) \\
\hline \multicolumn{3}{|c|}{ Mass } \\
\hline $\operatorname{gram}(\mathrm{g})$ & 0.03527 & ounce, avoirdupois (oz) \\
\hline \multicolumn{3}{|c|}{ Pressure } \\
\hline kilopascal (kPa) & 0.1450 & pound per square inch $\left(\mathrm{lb} / \mathrm{ft}^{2}\right)$ \\
\hline
\end{tabular}

Temperature in degrees Celsius $\left({ }^{\circ} \mathrm{C}\right)$ may be converted to degrees Fahrenheit ( ${ }^{\circ} \mathrm{F}$ ) as follows:

${ }^{\circ} \mathrm{F}=\left(1.8 \times{ }^{\circ} \mathrm{C}\right)+32$. 
This page left intentionally blank 


\title{
Biosecurity Plan for Palmyra Atoll
}

\author{
By Stacie A. Hathaway and Robert N. Fisher
}

\section{Executive Summary}

This Biosecurity Plan for Palmyra Atoll was developed for The Nature Conservancy (TNC) Palmyra Program to refine and expand goals and objectives developed through the Conservation Action Plan process. The Biosecurity Plan is one in a series of adaptive management plans designed to achieve TNC's mission toward the protection and enhancement of native wildlife and habitat. The Biosecurity Plan focuses on ecosystem security, and specifically identifies and addresses issues related to nonnative and potentially invasive species. The Plan attempts to identify pathways of invasion and strategies for preventing or reducing new introductions. Overall, the Biosecurity Plan provides a framework to implement and track the progress of conservation and restoration goals related to nonnative species on Palmyra Atoll.

Palmyra Atoll is one of the Northern Line Islands in the Pacific Ocean southwest of the Hawai ian Islands. It consists of many heavily vegetated islets arranged in a horseshoe pattern around four lagoons and surrounded by a coral reef. At present, Palmyra Atoll harbors various non-native or invasive species in the terrestrial and marine ecosystems. The most notable examples of terrestrial invasive species include coconut trees (Cocos nucifera) and black rats (Rattus rattus). Although it is unclear whether they are non-native, coconut trees are currently the most dominant plant across Palmyra Atoll. They compete with native plant species for space and resources, and are potentially detrimental to seabirds dependent on native vegetation. Black rats are known to predate ground-nesting seabirds and are likely responsible for the lack of burrowing seabird reproduction on Palmyra Atoll. The most notable example of a marine invasive species is the corallimorph (Rhodactis howsei). Although Rhodactis howsei is a native species, it can take advantage of human-altered habitat and significantly change the natural habitat by aggressively outcompeting native corals. Although the extent and impacts of these and other non-native and (or) invasive species are not fully understood, they are clearly a threat to the native species and overall ecosystem integrity of Palmyra Atoll.

In fact, non-native invasive species have been considered the most important threat to ecosystems in Hawai $i$ and the second most important threat to biodiversity world-wide. Palmyra Atoll is somewhat protected because of its remote location, but there are still potential pathways for the introduction of non-native and possibly invasive species. With the continued influx of aircraft and ocean vessels and their contents to and around Palmyra Atoll, we anticipate many more concerns related to the import and spread of non-native invasive species in the future.

In terms of ecosystem security, prevention is the most effective and efficient tool for managing invasive species. There are various potential pathways for introduction and spread of non-native species within Palmyra Atoll's terrestrial and marine ecosystems. Identification of these pathways provides a first step in preventing introductions. We also recommend establishing, enhancing, and enforcing quarantine protocols to prevent future non-native species invasions. Other critical steps to minimize the impacts and spread of invasive species include early detection through inventory and monitoring, as 
well as containment, control, and management of non-native species already established at Palmyra Atoll. These efforts in combination with research and education will serve to inform management decisions related to ecosystem integrity.

Along with reinstating ecosystem security, this Biosecurity Plan aims to evaluate new risk factors related to non-native and potentially invasive species. To that end, an adaptive management process of audit and review is highly recommended to ensure the implementation and efficacy of the management practices outlined above. In addition, it will be important to identify high risk, non-native species and potential invasion routes. An awareness of potential problem species will provide an important step in prevention. Lastly, the development of offsite controls could greatly reduce the potential of non-native species introduction. Non-native species possibly may be reduced at their sources through partnerships with relevant agencies and collaborative efforts.

We advise ongoing assessment of this Biosecurity Plan, as it contains strategies that require widespread cooperation and coordination in order to be effective. The Biosecurity Plan is a working document and subject to periodic review, refinement, and improvement as new information becomes available. The strategies associated with incipient and established non-native species will continue to be developed and should be implemented in an adaptive management framework. Constant review and evaluation of these biosecurity procedures will provide important management information to improve protocols and methods. Refining conservation goals via feedback loops will improve the ability of The Nature Conservancy and their partners to make effective decisions in evaluating and conserving ecosystem integrity.

\section{Introduction}

This Biosecurity Plan for Palmyra Atoll has been designed to assist The Nature Conservancy (TNC) in carrying out their Palmyra Atoll Program Mission and achieving the Palmyra Atoll Program Objectives. Based on assessments of the biological uniqueness and importance of Palmyra Atoll, TNC purchased the atoll in 2000 in order to preserve Palmyra's biological diversity. The Nature Conservancy now shares ownership of Palmyra Atoll. In 2001, Interior Secretary Bruce Babbitt signed a secretarial order creating a submerged lands refuge, which included about $22 \mathrm{~km}$ offshore of the emergent land of Palmyra Atoll. This acquisition was followed by the purchase of about $2.75 \mathrm{~km}^{2}$ of emergent land from TNC by the U.S. Fish and Wildlife Service (USFWS) in 2001. Together, these parcels represent the current extent of the Palmyra Atoll National Wildlife Refuge (PANWR).

This ownership results in TNC working in collaboration with the USFWS to identify and achieve consistent and compatible goals and objectives for Palmyra Atoll ecosystems. The mission of the National Wildlife Refuge System is 'to administer a national network of lands and waters for the conservation, management, and where appropriate, restoration of the fish, wildlife, and plant resources and their habitats within the United States for the benefit of present and future generations of Americans' (U.S. Fish and Wildlife Service, 2006). The purpose for which a refuge was established or acquired is of key importance to refuge planning and refuge purpose(s), and the Refuge System's mission forms the foundation for management decisions. The purposes of a refuge are specified or derived from the law, proclamation, executive order, agreement, public land order, donation document, or administrative memorandum that establishes, authorizes, or expands a refuge. The purpose of Palmyra Atoll National Wildlife Refuge is to preserve, restore, and enhance in their natural ecosystems (when practicable) all species of animals and plants that live at Palmyra Atoll, including those that are endangered or threatened with becoming endangered, and to conserve the migratory bird resources and coral reef ecosystem at Palmyra Atoll [Conceptual Management Plan for the Proposed Palmyra Atoll NWR (U.S. Fish and Wildlife Service, 2001)]. Current (2010) management programs on Palmyra Atoll 
primarily are focused on invasive species management, conservation of the Pisonia grandis forest, restoring altered lagoon hydrology, protecting seabird nesting colonies, and providing opportunities for the public to learn about wildlife resources through wildlife viewing, interpretation, and recreation (U.S. Fish and Wildlife Service, 2007).

The mission and purpose of Palmyra Atoll National Wildlife Refuge are thus in line with the TNC Palmyra Program Mission "To preserve, protect and restore Palmyra's unique ecosystem while facilitating valuable and responsible research through collaborative partnerships" (as posted at the Palmyra Atoll field station) and with TNC Palmyra Program management priorities, which include "'protection and enhancement of wildlife habitat" (Accessible at http://www.nature.org/wherewework/asiapacific/palmyra/about/). Therefore, management planning efforts should be compatible. This accord is important, as an ecosystem approach to management for Palmyra Atoll requires partner collaboration and coordination for adaptive management at an ecosystem level to be successful. Some important components in this approach include management planning, management implementation, monitoring, and research.

Elements of ecosystem management include sustainability, establishing goals, a sound basis in ecological models, understanding and recognizing the importance of biodiversity, structural complexity, the interconnectedness and dynamic character of ecosystems, the range of spatial and temporal scales, the role of humans in achieving sustainable ecosystem management goals, and the importance of adaptability and accountability (Christensen and others, 1996). This approach requires managers to have access to extensive information and data about the ecosystem, including historical and baseline conditions, the interactions among the components of the ecosystem, and the consequences of both natural and anthropogenic impacts. Often this information is unavailable, not easily accessible, or contains significant gaps. A series of adaptive management plans, including this Biosecurity Plan, are currently under development and will provide a step towards compiling up-to-date information about Palmyra Atoll.

Maintaining ecological integrity is often cited as the primary goal of ecosystem-based management. In fact, the National Wildlife Refuge System Administration Act of 1966, as amended by the National Wildlife Refuge System Improvement Act of 1997, 16 U.S.C. 668dd-668ee (Refuge Administration Act) Section 4(a)(4)(B), states that "In administering the System, the Secretary shall ...ensure that the biological integrity, diversity, and environmental health of the System are maintained for the benefit of present and future generations of Americans." This is 1 of 14 directives to the Interior Secretary contained within the Refuge Administration Act. In an effort to achieve this directive and as part of the overall conservation planning efforts for Palmyra Atoll, this Biosecurity Plan is being developed to begin identifying and addressing issues relating to non-native and potentially invasive species. Various experts have been consulted for information relevant to Palmyra Atoll throughout the process of developing this management plan (table 1). 


\section{Study Site}

Palmyra Atoll is at about $6^{\circ} \mathrm{N},-162^{\circ} \mathrm{W}$, and about $1,600 \mathrm{~km}$ southwest of Honolulu (fig. 1). Palmyra Atoll is at the northern end of the Line Islands close to the Inter-Tropical Convergence Zone. The climate is characterized by high humidity $(>90 \%)$ and warm temperatures $\left(24-27^{\circ} \mathrm{C}\right)$. Palmyra Atoll is considered a wet atoll, receiving nearly $4,500 \mathrm{~mm}$ of rain per year. It currently consists of many islets, most of which are heavily vegetated. The islets generally do not exceed $2 \mathrm{~m}$ in elevation. The islets vary in size and are arranged in a horseshoe pattern around four lagoons, all surrounded by coral reef. The terrestrial ecosystem supports what is considered some of the best remaining Pisonia grandis forest and large colonies of seabirds, including one of the largest colonies of red-footed boobies (Sula sula) in the world and significant numbers of migratory shorebirds. Palmyra Atoll also is home to some of the most pristine coral reefs in the world.

\section{Background}

Palmyra Atoll likely was explored by Micronesians and Polynesians, but was never inhabited. The first known western discovery of the atoll by Edmond Fanning was in 1798; however, the atoll was officially discovered and named in 1802 by Captain Sawle of the ship Palmyra. In 1859, Dr. G.P. Judd of the American brig Josephine claimed possession of the atoll for the U.S. and American Guano Co. In 1898 under the leadership of President McKinley, Palmyra Atoll was acquired in the U.S. Joint Resolution of the 55th Congress, which annexed the territory of Hawai i, including Palmyra. In 1911, Judge Henry E. Cooper of Honolulu bought Palmyra Atoll and later sold it to the Fullard-Leo family. There was a short period of military use from 1940 to 1945 during which the atoll and lagoon were modified greatly. In 1947, the Fullard-Leo family reclaimed ownership by U.S. Supreme Court decision. In 1959, Hawai i became the 50th State, but Palmyra Atoll was specifically excluded, making it a privately owned U.S. Territory. Human use of Palmyra Atoll was fairly minimal before military activity. There were attempts to identify a lucrative guano business and multiple attempts to plant coconuts for copra; however, these ventures never panned out. After the military left, use of the atoll gradually reduced in intensity with only a few known long-term stewards and occasional visitation by recreational vessels. Infrastructure left by the military has continued to be used over time (e.g., airstrip, dock, some of the roads), has been modified over time for use (e.g., water catchment system), or has been essentially abandoned (e.g., hospital building, bunkers, pillboxes). In August 2000, TNC purchased emergent lands, and on January 18, 2001, by Secretarial Order \#3224, Palmyra Atoll was established as a National Wildlife Refuge and now includes all emergent land (with the exception of Cooper and Menge Islets retained by TNC) and the area about $22 \mathrm{~km}$ beyond. [However, there are nine areas of tidal and submerged lands excluded from this transfer totaling about $491.5 \mathrm{~km}^{2}$ that remain under the jurisdiction of the Deputy Assistant Secretary of Insular Affairs (Department of Interior Office of Insular Affairs, 2006)]. Palmyra Atoll, one of a few atolls without a long settlement or fishing history, is now managed for conservation and recovery of native habitats. 


\section{Terrestrial Non-Native or Invasive Species at Palmyra Atoll}

At present (2010), Palmyra Atoll harbors various non-native species in terrestrial and marine ecosystems. These species have the potential to be invasive, defined by Executive Order 13112 (Executive Order 13112) as a species whose introduction has caused or may cause harm to environmental or human health (National Invasive Species Council, 2008). Through visitation and various uses, non-native species have been historically intentionally and unintentionally introduced to Palmyra Atoll by humans. Although Palmyra Atoll is remote and now protected, there is still human visitation for refuge management, scientific research, and recreation purposes. With this continued influx of aircraft, vessels, and their contents to and around Palmyra Atoll comes the potential to import and move non-native and potentially highly invasive species. Non-native and invasive species can negatively affect the native ecosystems in various ways, including competition, hybridization, habitat modification, predation, and disease transmission. Of the many potential threats to Palmyra Atoll ecosystems, non-native species are certainly one of the most urgent and preventable. Mandatory quarantine protocols should be developed, implemented, and reviewed regularly for updates to reduce the potential introduction and spread of new species at Palmyra Atoll. Control, eradication, and, where necessary, restoration plans associated with incipient and established non-native species should continue to be developed and implemented in an adaptive management framework. Consequently, monitoring plans are necessary to ensure the efficacy of these actions and reduce negative impacts. In addition, this continual monitoring will be providing important management information to improve protocols and methods to be applied here and in similar environments.

\section{Non-Native or Invasive Vascular Plants}

Over time, various non-native plants and animals were introduced intentionally and unintentionally with increasing human visitation to Palmyra Atoll. It has been documented that various non-native plants were brought as ornamentals and food sources (Rock, 1916, 1929; Dawson, 1959). In fact, of the 129 plants recorded from Palmyra Atoll [including two species newly identified by Herbst in 2002 that are not included in any available reports (C. Depkin, U.S. Fish and Wildlife Service, oral commun., 2008)], only 27 are considered native species when including three varieties of Pandanus fischerianus, as described by Herbst (1987, 1992)(Herbst, 1987, 1992; Freeman, 2006). Of the 102 identified non-native species, many are considered extirpated at Palmyra, and it is unlikely most of these species could persist without human assistance. Recent assessments of the number of terrestrial vascular plant species known to be present on Palmyra Atoll as reported by Freeman (2006) suggest 78 vascular plant species were still present on the atoll. Twenty-five of these were considered native species, meaning 53 non-native species were considered still present. However, recent overall species lists had contradictory information regarding the current status of several species, and some species may still be present and others may have since become locally extinct or been eradicated there.

The first potentially non-native species known to Palmyra Atoll may be Cocos nucifera. The exact time and means of arrival is uncertain; thus, whether this species arrived on its own or through human assistance is unclear. However, it has been documented that attempts to cultivate this species continued for many years. This species is now the dominant plant across the atoll, comprising about $45 \%$ of the canopy, and the Cocos forest type (combining monotypic and stands mixed with other species) covers about $40 \%$ of the atoll's land area (Wegmann, 2005). Probable impacts of this potentially non-native species and others include the reduction of native species, their extent, and the habitat they provide for other species. Other impacts of invasive and non-native species are being examined (e.g., the role of Cocos nucifera and nutrient cycling (H. Young, Stanford University, oral 
commun., 2008). The full extent of invasive and non-native species impacts on Palmyra Atoll is unknown and should be investigated.

\section{Non-Native Animals}

In addition to non-native plant species, many inadvertent and a few intentional introductions of non-native animal species have taken place on Palmyra Atoll (tables 3 and 4). The most detrimental of these was perhaps the introduction of rats (Rattus rattus). Rats are well known to have severe effects on the ecosystems they invade (e.g., U.S. Fish and Wildlife Service, 2002, 2005; numerous papers in Veitch and Clout, 2002; Engilis and Naughton, 2004; Howald and others, 2004; Buckelew and others, 2005; Towns and others, 2006; Jones and others, 2008). The literature reports that rats are responsible for the loss or reduction of several species of seabirds. There are no burrowing bird species at Palmyra Atoll, and several ground nesters and overwintering shorebirds are thought to be adversely effected by rats. Rats also are thought to be responsible for the lack of burrowing nesters breeding on Palmyra Atoll, such as the shearwater (Puffinus) and petrel (Halobaena) species often observed offshore (Depkin, 2002; J. Smith, University of Washington; M. McKown, University of North Carolina; E. Flint, U.S. Fish and Wildlife Service; L. Balance, National Oceanic and Atmospheric Administration; R. Pitman, National Oceanic and Atmospheric Administration, oral commun., 2008). Rats have been observed to be avid predators of ground-nesting breeders, particularly sooty terns (Onychoprion fuscatus) on Palmyra Atoll (A. Wegmann, University of Hawai' i; H. Young, Stanford University, oral commun., 2008). Further, rats at Palmyra Atoll have been observed attacking hermit crabs (e.g., Coenobita perlatus), and land crab carapace pieces are common items in rat husking stations (A. Wegmann, University of Hawai i, oral commun., 2008; R. Fisher, U.S. Geological Survey oral commun., 2008). It also is thought that rats are responsible for a reduction in native plant species by killing seeds and seedlings. Rat and crab seed and seedling experiments indicate that rats kill and disperse seeds where they will not germinate, while crabs manipulate seeds but do not kill them and they disperse seeds randomly (A. Wegmann, University of Hawai' i, written commun., 2008). However, Wegmann also has found that rats kill non-native plant seeds such as Terminalia catappa, which may be slowing the expansion of this and other non-native plants.

The Nature Conservancy, in conjunction with the USFWS, initiated a rat eradication program on Palmyra Atoll in 2001. This eradication program was an attempt to restore Palmyra Atoll's terrestrial ecosystem. It was suspended in August 2003 after it became apparent that rats could not be eradicated at Palmyra Atoll through the methods in use and that the program needed to be reviewed. In spring 2004, Island Conservation and TNC secured funding to conduct a site assessment on Palmyra Atoll and develop specific recommendations, techniques, and options to complete the rat eradication. In August 2004, a team of people with experience in island rodent eradication or control visited Palmyra Atoll to gather information for trial eradication and to begin planning the successful eradication of rats from Palmyra Atoll (Howald and others, 2004). Radio-telemetry data comparing movements of rats livetrapped in coconut palms with rats trapped on the ground revealed that rats on Palmyra live in a threedimensional environment, and regularly move between the tree canopy and the ground. The ranging or planar movements of rats captured on Palmyra were particularly small, leading researchers to believe that rats did not encounter or only infrequently encountered bait stations previously spaced at $50-\mathrm{m}$ intervals. The rat eradication program is an example of adaptive management already taking place at Palmyra Atoll. Rat removal was attempted, it failed, experiments were conducted to improve methods, and the resulting information could be used to determine why rat removal had failed and to improve future plans. Planning is now underway to continue the removal program using new evidence to increase success. 
Another non-native mammal, the feral cat (Felis catus), has been observed on Palmyra Atoll with the most recent observations made in 2007 and 2008 on the southern islets (S. Hathaway and R. Fisher, U.S. Geological Survey, oral commun., 2007; W. Smith, U.S. Fish and Wildlife Service; H. Young, Stanford University, oral commun., 2008). These observations were of individual cats, and numbers of these animals are currently unknown. It is suspected that cats have periodically been released by passengers of visiting vessels. Cats have been implicated as having devastating effects on native species, including playing a role in the severe reduction or extinction of many species (Iverson, 1978; Kirkpatrick and Rauzon, 1986; Rodriquez and others, 2006; Medina and Nogales, 2009). Regular monitoring and eradication should be a high priority. Flint and others (1992) reported other non-native mammals, including domestic pigs (Sus domestica), which are no longer present and a domestic dog (Canis familiaris). At present, two domestic cats and one domestic dog are cared for by TNC and restricted to Cooper, Menge, and Strawn Islets.

The mynah (Acridotheres tristis) has been reported at Palmyra Atoll as an introduced but now eradicated species (Clapp as cited in Fefer, 1987). Domestic chickens (Gallus gallus) also were reported (Flint and others, 1992), but are no longer present.

There are two species of non-native geckos: the mourning gecko (Lepidodactylus lugubris) and the house gecko (Hemidactylus frenatus). The mourning gecko is a parthenogenic species and is represented on the atoll by many different clone types of which there may be both native (clone types that arrived on their own) and non-native (clone types that arrived by human assistance) clone types). These species may be responsible for transmitting parasites and out-competing native geckos. House geckos are currently centered around the urban core on buildings, and new poison baits being developed in New Zealand might be appropriate for attempting removal experiments (T.Whittaker, Ecological Consultant, oral commun., 2008).

Another non-native, potentially invasive species at Palmyra Atoll, the marine toad (Bufo marinus), has not been observed since 2002 (S. Barclay, U.S. Fish and Wildlife Service, oral commun., 2008). Additional non-native reptile and amphibian species are most likely to be introduced during movement back and forth to Hawai $i$ where various species could get into cargo. The ability of these species to become established may be reduced by predation from rats. Data have not yet been collected to provide evidence that rats are currently reducing existing non-native reptile species populations. However, this possibility should be considered prior to rat eradication. Early identification of potential cascading effects such as this and, where possible, implementations of preventive measures could have the benefit of immediately reducing non-native species introduction. In addition, this would allow for modifications and improvements to protocols before the atoll potentially becomes more vulnerable in the absence of rats.

There are a few native species of arthropods, but most of the 162 species recorded from Palmyra Atoll are considered to be non-native accidental introductions presumably coming from Hawai i (table 4)(Handler and others, 2007). The most destructive arthropods include the scale (Pulvinaria urbicola), other hemipterans (including white fly, Aleyrodidae G. sp.), and mealy bugs (Dysmicoccus brevipes, D. neobrevipes, Ferrisia virgata, and Planococcus citri). Ants also are highly destructive. Several species of invasive ants have been observed to be lethal when they swarm on young seabird chicks (U.S. Fish and Wildlife Service and others, 2008). However, the ant, Pheidole megacephala, is of particular concern because it is considered to be primarily responsible for tending scale and other hemipteran species that feed on native plants and have been implicated in the decline of the native Pisonia grandis (E. Nonner U.S. Fish and Wildlife Service; L. Woodward U.S. Fish and Wildlife Service, unpub. data, 2009). These hemipteran species also develop honeydew known to promote the sooty mold covering plants, and potentially reducing photosynthesis and increasing stress in the plant. An informal survey of 
the distribution of hemipterans on plant species at Palmyra Atoll revealed that only $9 \%$ of plant species surveyed did not have infestations and one of the unaffected plant species was Cocos nucifera (Freeman, 2006). Freeman (2006) found nearly 67\% of all plants to be associated with white fly, $40 \%$ with mealy bugs, $28 \%$ with scale, and $18 \%$ with aphids.

Wasps and mosquitoes also are problems on Palmyra Atoll. Mosquitoes are of particular concern because they are potential vectors for various human and wildlife diseases. Two of the mosquito species, recently identified by Handler and others (2007), are clearly threats. Aedes albopictus has a wide host range, including humans and birds, and is a known potential carrier of dengue and West Nile Virus (Kyle and Harris, 2008). Culex quinquefasciatus is a potential vector for avian diseases, including avian malaria, avian pox, and West Nile Virus (van Riper III and others, 2002; Ladeau and others, 2008).

No reports were found referring to the presence of terrestrial non-native invasive pathogens at Palmyra Atoll.

\section{Marine Non-Native or Invasive Species}

There have been only a few marine non-native species reported from Palmyra Atoll (table 5). However, a native species is the most evident invasive marine species on Palmyra Atoll at this time. A corallimorph (Rhodactis howsei) associated with the fishing vessel Hui Feng No 1 shipwreck has been aggressively outcompeting other native corals. Recent evaluations of this invasion documented high densities of this species causing a phase shift from coral near the wreck and decreasing with distance (Work and others, 2008). Work and others (2008) found this species to be rare or absent in other areas of the atoll, but found it associated with other manmade structures. This corallimorph is an example of a species taking advantage of human-altered habitat and significantly changing the natural habitat. The prevailing hypothesis suggests that iron enrichment (leaching from manmade structures) is facilitating the explosive growth of this species, but the idea remains untested.

Work and others (2008) suggest removing the wreck and experimenting with sterilizing the affected areas as potential management actions. Minimally, continuing to monitor this area to quantify the rate of spread of this corallimorph and other potentially invasive species in order to further justify management action is advised. This example illustrates the importance of acting quickly to minimize the extent of damage and increasing the likelihood of containment and restoration.

Other non-native marine species include an alga that was found at a mooring buoy in the lagoon (B. Morgan, The Nature Conservancy, oral commun., 2008). In addition, two unidentified non-native sponge species, one hydroid (Pennaria disticha), one barnacle (Balanus amphitrite amphitrite), and one tunicate (Diplosoma listerianum) have been reported at Palmyra Atoll. All these species also have been introduced in Hawai $i$ (Godwin and Vroom, as cited in Brainard and others, 2005). Finally, the presence of coral disease has been reported in four genera of coral (Williams and others, 2008).

Non-native invasive species have been considered the most important threat to ecosystems in Hawai $i$ and the second most important threat to biodiversity worldwide. The examples presented above specifically illustrate the potential vulnerability of Palmyra Atoll. Palmyra Atoll is somewhat protected because of its remote location, but there are still potential pathways for new introductions of non-native, potentially invasive species. The Biosecurity Plan for Palmyra Atoll is an initial attempt at identification of these pathways and strategies for reducing the potential for new introductions. 


\section{Existing Non-Native Species Laws, Policies, Protocols}

Biosecurity is a concern at various scales from global to local. Prevention and control policies have been and continue to be developed at various levels of government. These policies can be expanded for increasing success in non-native/invasive species management at all levels. This section provides a brief introduction to some of the policies and programs that are currently in place that directly or indirectly address non-native species issues at Palmyra Atoll.

\section{International}

The International Plant Protection Convention signed by the United States in 1951 and ratified in 1972 applies primarily to the quarantine of pests, "any form of plant or animal life, or any pathogenic agent, injurious or potentially injurious to plants or plant products" in international trade.

The Convention on Biological Diversity is an International Treaty to sustain the diversity of life with provision for parties to "prevent introduction of, control or eradicate alien species which threaten ecosystems, habitats, or species" and was signed by the United States in 1993. However, ratification has not been completed.

In 1997, The International Maritime Organization (IMO) recognized vessel hull fouling and ballast water discharge as two major vectors for transporting alien species in marine environments and the IMO developed ballast water exchange guidelines (International Maritime Organization 1997, 2001).

\section{National}

The Lacey Act (1900) as amended in 1998 (18 U.S.C. 42, 16 U.S.C. 3371) declares the importation or transportation of a designated list of live wildlife to be injurious and prohibited except as provided under this Act, such as for scientific, medical, educational, exhibition, or propagation purposes.

The National Environmental Protection Act (1970) requires federal agencies to consider the effects of actions, including those on non-native species that may be harmful to the environment through preparation of environmental impact statements.

The Endangered Species Act (1973) permits the eradication of non-native species posing a threat to endangered species.

The National Invasive Species Act (1996) (Public Law 104-332) reauthorizes and amends the Nonindigenous Aquatic Nuisance Prevention and Control Act (1990) (16 U.S.C. 4701) to have broader application, including the development and implementation of a comprehensive program to control the brown tree snake in Guam.

The 1999 Executive Order 13112 on Invasive Species established the National Invasive Species Council (NISC) and requires the development of a National Management Plan for Invasive Species.

The Plant Protection Act (2000) consolidates and modernizes major statutes pertaining to plant protection and quarantine, including all types of weed issues, and authorizes the U.S. Department of Agriculture, Animal Plant Health Inspection Service to take emergency and extraordinary action in addressing noxious weed incursions. 
The 2004 U.S. Coast Guard's Mandatory Ballast Water Management Program for U.S. waters is a ballast water management program for all vessels with ballast water tanks entering or operating within U.S. waters. This program requires vessels to maintain a ballast water management plan and to assign an appropriate official to understand and execute the ballast water management strategy specific to that vessel.

\section{State of Hawai i}

Although Palmyra is not a part of the State of Hawai $i$, the structures and policies in place for the State have direct bearing on management of biosecurity at Palmyra because most vessels and flights to the atoll originate in Hawai $i$ and because procedures developed in Hawai $i$ likely will be helpful at any tropical Pacific site.

Hawai'i's Comprehensive Wildlife Conservation Strategy (Mitchell and others, 2005) and Aquatic Invasive Species Management Plan (Department of Lands and Natural Resources, 2003) address the threats posed by invasive species and the strategies for achieving conservation objectives. These objectives include working toward developing prevention and control measures. The strategies are ongoing and carried out with the efforts of numerous entities from local, State, and Federal agencies, non-governmental organizations, private landowners, and citizens.

Invasive Species Committees of Hawai'i (ISCs) are voluntary partnerships of private, governmental, and non-profit organizations, and individuals working together to address invasive species issues particular to the island. The overall goal of the ISCs is to prevent, eradicate, or control priority incipient plant and animal species that threaten Hawai i's most intact Federal, State, and private conservation lands. The first ISC in Hawai'i was formed on Maui (MISC) in 1997 in response to the need for an early detection of and rapid on-the-ground response to an array of incipient invasive species. These ISCs are now in place on every major Hawai ian island (Kaua `i -KISC, O`ahu -OISC, Maui, Moloka ' $\mathrm{i}$-MoMISC, and Big Island -BIISC).

Two additional groups addressing invasive species issues are the Hawai'i Invasive Species Council (HISC), a government body with funding and policy authority, and the Coordinating Group on Alien Pest Species (CGAPS), a multi-agency partnership aiming to facilitate coordination for greater effectiveness.

The Hawai' ian legislature designated the Department of Land and Natural Resources (DLNR) Division of Aquatic Resources (DAR) as the lead agency for the State of Hawai i for preventing the introduction of non-natives through ballast water and hull fouling. In 2007, the DLNR adopted Title 13, chapter 76, Hawai ${ }^{1}$ Administrative Rules (non-indigenous species) to manage ballast water discharge from vessels operating in Hawai' ian waters (appendix 9). The Aquatic Invasive Species Management Plan of DAR addresses prevention and eradication of marine invasive species in Hawai ${ }^{1}$.

\section{Palmyra Atoll}

Much of Palmyra Atoll is a National Wildlife Refuge and the development of a Comprehensive Conservation Plan (CCP) is currently underway. The goals and objectives developed and strategies identified to achieve them, as identified within this CCP, will ultimately serve as the guidance for operations at PANWR. This Biosecurity Plan document may provide preliminary operational guidelines for TNC and serve as part of its effort in contributing toward the development of the PANWR CCP. Finally, this draft with approval could be used in the interim as a guide for biosecurity measures. 
A biosecurity plan acts as an effective tool for identifying and addressing non-native, potentially invasive species problems and concerns. Some specific benefits have been suggested by the Federal Aquatic Nuisance Species (ANS) Task Force (2000) for developing ANS plans (also relevant to the terrestrial ecosystem) and include

- Describing activities underway in the geographic area covered and providing opportunities for improving the coordination and effectiveness of involved organizations.

- Describing and documenting non-native, invasive species problems and the roles of the involved organizations for systematically prioritizing and resolving those problems.

- Informing the public of problems and solutions through participation in the process and by sharing the plan with the public. This information sharing should yield more support for addressing problems and for taking actions to reduce invasive species impacts.

- Encouraging organizations in the same geographic area to share information; develop consistent, coordinated and complementary plans; reduce duplication of effort; and collaboratively support implementation.

- Improving collaboration between national, regional, state and local efforts.

All non-native and native species have the potential to become invasive. Various factors can influence potential invasiveness, and these factors may not be apparent within the species' native range, especially where the invaded habitat lacks the competition and predation pressures present in the native habitat. These complications make assessing risk very difficult and support focusing on prevention of non-native species introductions and spread. Therefore, although this document is ultimately intended to be a comprehensive biosecurity plan, the current focus is on increasing efforts to prevent the introduction of new species. As this plan continues through the refinement process, additional attention will be needed for strategizing components to a greater extent in order to successfully achieve biosecurity goals.

Though preliminary biosecurity measures are currently in place to prevent additional non-native and invasive species from being introduced to and moved throughout Palmyra Atoll, they are largely unenforced. Current protocols include the TNC-distributed Palmyra Atoll Trip Orientation Documents, which instruct visitors arriving by plane to freeze clothes for $48 \mathrm{hrs}$ prior to entry. Once on Palmyra Atoll, there is a requirement to freeze clothes for $48 \mathrm{hrs}$ prior to moving from Cooper to other islets. There appear to be no quarantine measures currently in place to prevent non-native and invasive species from being introduced to the marine ecosystem at Palmyra Atoll. The TNC documents Palmyra Atoll Visiting Vessels Documents currently do not indicate any biosecurity measures for marine or terrestrial precautions for any vessel or its contents and passengers. Thus, additional measures are in need of development. These needs are further addressed in the section, "Palmyra Atoll Biosecurity Goals, Objectives, and Strategies." Although relevant existing documents were requested at the start of this effort, we have recently become aware that there are conditions included in the USFWS document Special Use Permits issued for use by the National Wildlife Refuge that were not originally made available. Thus, these conditions have not been reviewed here. If possible, TNC should acquire this document and incorporate the conditions relevant to the biosecurity of Palmyra Atoll. 


\section{Goals and Objectives of the Biosecurity Plan for Palmyra Atoll}

\section{Goal (G1) Reinstate Ecosystem Security}

Reinstate secure conditions and minimize unacceptable change to ecosystem structure in which accidental or intentional human intervention has disturbed or altered the ecosystem.

To assist in achieving this goal, several major objectives have been identified:

(G1-O1) Prevention - Minimize new invasive species introductions.

(G1-O2) Early Detection - Conduct invasive species assessments.

(G1-O3) Response - Eradication of incipient invasive species.

(G1-O4) Response - Develop stepdown plans for eradication or control of the spread of established invasive species.

(G1-O5) Research - Support, promote, and coordinate research and monitoring of relevant nonnative and invasive species and related issues at Palmyra Atoll to improve non-native species management decision making.

(G1-O6) Education - Ensure awareness of threats and protocols.

\section{Goal (G2) Monitor New Risk Factors-Develop Ongoing Assessment}

Identify priority risk factors (terrestrial and marine species) that might threaten the Palmyra Atoll system and continue to track changing risk factors over time as potential sources are changing (e.g., Honolulu, Kiritimati).

To assist in achieving this goal, several major objectives have been identified:

(G2-O1) Adaptive management audit and review.

(G2-O2) Identify priority risks - Evaluate priority potential risk species in source sites for invasion into Palmyra Atoll. Assess potential invasion routes.

(G2-O3) Develop offsite controls - Evaluate potential for reduction of non-native species at the source to reduce the potential for priority species to gain access to Palmyra Atoll.

\section{Scope and Limitations of this Biosecurity Plan}

There are limitations to the scope of the Biosecurity Plan for Palmyra Atoll. As mentioned above, this plan is not yet meant to be comprehensive, and it should be recognized that it is still in the development process. As stated, the focus of this plan has been prevention, and although these strategies are in the preliminary stages, further development of other objectives and strategies in the plan is needed. This plan was done in an attempt to be realistic about where efforts could be initially focused in the current draft and is not meant to indicate that other aspects are not important, but is meant to be an effort to tackle the highest priorities first. There is still a need to expand on the current objectives and strategies and potentially even modify goals as deemed necessary through application of the adaptive management approach to the subsequent updates to the plan as efforts planned for the near-term are refined and implemented. 


\section{Palmyra Atoll Biosecurity Goals, Objectives, and Strategies}

\section{Goal (G1) Reinstate Ecosystem Security}

Reinstate secure conditions and minimize unacceptable change to ecosystem structure in which accidental or intentional human intervention have disturbed or has altered the ecosystem.

\section{Desired Future Conditions}

A secure and stable state is denoted by removal of non-native or anthropogenic stressors that have or will cause ecosystems to degrade or be damaged. This state is denoted by ecosystem equilibrium rather than stasis. Successful interception of potential invaders needs to be enhanced through policies and protocols.

\section{Goal (G1) Objectives}

\section{(G1-01) Prevention}

Minimize new invasive species introductions and spread. Proactively develop, implement, and enforce biosecurity, quarantine, and preventative management strategies.

Strategy (G1-O1-S1).- - Identify potential pathways for introduction and spread of non-native species. There are various potential pathways for introduction and spread of non-native species within Palmyra Atoll's terrestrial and marine ecosystems. Identification of pathways that range from global to local provides a first step in the ability to strategize ways to prevent introductions. Pathway lists can be developed and expanded upon with additional known or suspected pathways aiding in the formation of a more comprehensive list.

Task (G1-O1-S1-T1). - Draft potential pathways for the introduction and spread of non-native species for Palmyra Atoll.

Task Status. - Some pathways with the potential to introduce and spread non-native species to and around Palmyra Atoll had previously been identified, such as clothing and shoes. Additional pathways continue to be considered, but no documentation of these could be located. A draft list of potential pathways has been developed (see appendix 1, Potential Non-Native Species Introduction Pathways Relevant to Palmyra Atoll). 
Strategy (G1-O1-S2).-Enhance existing quarantine protocols intended for implementation prior to entry to Palmyra Atoll and surrounding waters. Current protocols and quarantine procedures prior to entering Palmyra Atoll are minimal requirements and are not currently being enforced, nor do they currently include marine ecosystems. There is a need to further develop procedures and notification for all aircraft, vessels, passengers, and supplies coming to Palmyra Atoll prior to their arrival.

Task (G1-O1-S2-T1).-Enhance and (or) draft protocols for securing potential pathways introducing non-native species to Palmyra Atoll.

Task Status. - Draft protocols (appendixes 2-8) have been under development for Palmyra Atoll relevant to

- Quarantine protocol for aircraft traveling to Palmyra Atoll.

- Quarantine protocol for persons traveling to Palmyra Atoll.

- Quarantine or exclusion of fresh foods or packaging with high likelihood of risk of non-native species introductions intended for delivery to Palmyra Atoll.

- Quarantine protocol for cargo vessels traveling to Palmyra Atoll.

- Quarantine protocol for freight consolidation areas and cargo intended for delivery to Palmyra Atoll.

- Quarantine protocol for visiting vessels (those with pre-permission, traveling through the Pacific on personal sail or motor vessels) traveling to Palmyra Atoll.

- Quarantine protocol for unexpected ships (including vessels in distress) requesting permission to travel to Palmyra Atoll.

Strategy (G1-O1-S3). - Enhance existing quarantine protocols intended for implementation before moving between islets or within the local marine environments within Palmyra Atoll National Wildlife Refuge boundaries. Current protocols and quarantine procedures for moving around Palmyra Atoll have minimal requirements and are not currently being fully enforced. There is a need to further develop procedures and notification for all vessels, passengers, and equipment moving within the terrestrial and marine ecosystems of Palmyra Atoll.

Task (G1-O1-S3-T1).-Enhance and (or) draft protocols for securing potential pathways that may spread non-native species around Palmyra Atoll.

Task Status. - Draft protocols (appendixes 2 and 9) have been under development for Palmyra Atoll relevant to

- Quarantine protocol for near-shore transportation throughout Palmyra Atoll.

- Quarantine protocol for equipment use throughout Palmyra Atoll.

Strategy (G1-O1-S4).- Implementation and enforcement of existing and newly developed quarantine protocols are necessary prevention measures. Developing a procedure to ensure quarantine procedures are followed will be beneficial to making quarantine a priority.

Task (G1-O1-S4-T1). - Develop inspection and other "prevention" measures to ensure prevention protocols are implemented to prevent or reduce high-risk invasive species and diseases from entry and spread across Palmyra Atoll.

Task (G1-O1-S4-T2).- - Require compliance with upcoming regulations, such as ballast water regulations and support development of similar regulations, such as for hull fouling. 


\section{(G1-02) Early Detection}

Conduct invasive species assessment. Inventory current non-native species across Palmyra Atoll and evaluate all management activities (e.g., monitoring, restoration, research, recreation) with respect to their potential to accidentally introduce or increase the spread of invasive species. Early detection of new non-native species through surveillance and monitoring is an important aspect of any biosecurity plan providing managers with a full range of potential response options, which include eradication, containment, control, and doing nothing. Without adequate surveillance for non-native species, early detection may not occur, and this potentially allows for increases in numbers and (or) distribution of non-native, invasive species, which may decrease the chances of effective eradication or control, and inability to respond becomes more likely.

Strategy (G1-O2-S1).- Inventory all known non-native species and their spatial and temporal distributions.

Task (G1-O2-S1-T1).-Compile species lists of all known non-native species on Palmyra Atoll from all published and unpublished literature and all site knowledge available.

Task Status.-Preliminary species lists are included in tables 2-5.

Task (G1-O2-S1-T2). - Develop and maintain an incidental observation log system and encourage visitors to Palmyra Atoll to enter relevant information, such as species names, descriptions, location information, and date of observation for any known or suspected nonnative species. Review and verify observations regularly, and where necessary carry out response measures.

Task (G1-O2-S1-T3). - Develop and maintain maps in a Geographic Information System (GIS) containing the spatial and temporal distributions of non-native species. For terrestrial species, this process can begin with mapping the information presented in "Vascular Flora of Palmyra Atoll National Wildlife Refuge: An update to 1992" (Freeman, 2006) describing individual species' distributions as baseline. This information can be supplemented with data collected by Depkin (2002) and any additional information as it becomes available. Arthropod distribution data are scarce, but scale has been followed through Pisonia grandis censusing, and the level of scale infestation of Pisonia grandis can be mapped by islet as a start. Non-native gecko distributions are currently being mapped as part of an atoll-wide assessment with the coastal areas of the atoll nearly complete and inland areas pending completion. Maintaining maps of past and current distributions of non-native species is useful for identifying the extent of invasion, likely sources of movement and points of entry across the atoll for prioritization and focusing prevention, and monitoring and eradication efforts. For marine species, the distribution of the corallimorph associated with the fishing vessel Hui Feng No 1 shipwreck has recently been published (Work and others, 2008). As more data become available through current and future research and potential new management and monitoring, these data also should be contained within a mapping program to assess distribution and spread.

Strategy (G1-O2-S2). - Early detection monitoring: Currently baseline data about the occurrence of some pests on Palmyra Atoll is variable. There is no regular 'risk' site monitoring for new nonnative species. Although the entire atoll is vulnerable to introduction, it is most likely that particular areas will be at higher risk of non-native species introductions. Risk sites are essentially locations where there is a higher likelihood of a new non-native species incursion. Identification of high risk 
sites will enable efficient use of resources for detecting new introductions. Monitoring protocols for non-native species need to be developed and implemented.

Task (G1-O2-S2-T1). - Identify 'risk sites' where new non-native species are more likely to establish.

Task Status.- - High risk sites already identified include all areas with regular human activities. A preliminary assessment for the terrestrial ecosystem includes locations, such as the airstrip and all trails and areas where structures have been recently in use, as well as those areas repeatedly visited for research and recreation. These criteria minimally include most of Cooper/Menge and Strawn Islets, and although use is much lower at Sand Islet, it is visited regularly for scientific and educational purposes and would benefit from surveillance. A list of more specific sites for monitoring could be developed based on current known distributions, habitat requirements of the non-native species known to occur at Palmyra Atoll, and knowledge regarding any species of high concern for introduction. For the terrestrial system, high risk sites would include locations surrounding known infestations, such as on Engineer Islet where Epipremnum pinnatum covers the old hospital building and neighboring trees, including Pisonia grandis. For the marine ecosystem, the fishing vessel Hui Feng No 1 shipwreck is currently invaded by corallimorphs and monitoring should continue. Other high risk sites may include similar man-made structures, particularly those leaching iron. The dock and ripple wharf are areas of high use and should be included in monitoring. Additional sites can be identified by evaluating other sites used for research and recreation and prioritizing them based on frequency and extent of use, as well as patterns of non-native species observations made during these activities.

Task (G1-O2-S2-T2). - Develop and implement non-native species monitoring protocols for high risk sites and general atoll-wide surveys. Monitoring could be a mix of techniques (e.g., trapping for insects and other animals, along with visual sampling surveys using developed protocols). The actual number of sites, the optimal frequency of inspections, and methods need to be developed.

Strategy (G1-02-S3).-Develop a procedure for evaluating activities (including maintenance, management, research, restoration, recreation, and others) occurring on Palmyra Atoll for the potential to introduce and (or) move non-native species. This procedure enables managers to assess the risk involved with various activities, to increase awareness for the potential to introduce or spread non-native species, and to provide a mechanism for improving existing protocols. For example, supplies and equipment transported to Palmyra Atoll have the potential to harbor nonnative seeds, insects, and other non-native species. In addition, there is a need to evaluate the risks associated with movement of vehicles from Cooper Islet to other islets and other inter-islet traffic [e.g., kayaks, boats, and equipment are known to transport plant matter and animals, such as insects and lizards (S. Hathaway and R. Fisher, U.S. Geological Survey, oral commun., 2007)]. Likewise, using equipment that is intentionally or unintentionally in contact with the marine environment at different snorkeling and diving sites across the atoll is likely to increase the risk of spreading nonnative species and disease. These types of scenarios should be assessed for risk and protocols developed to minimize or eliminate that risk.

Task (G1-O2-S3-T1).- - Develop activity evaluation procedure to examine risk of introduction or spread of non-native species at Palmyra Atoll. Hazard Analysis-Critical Control Point 
(HACCP) planning is an international standard (American Society for Testing and Materials E2590-08) for reducing or eliminating the spread of unwanted species during specific processes or practices or in materials or products. HACCP planning was originally developed and is used for food industry safety and has been modified for use with natural resource management. HACCP planning has been used by various organizations and agencies, including the USFWS. Guides, wizards, and previously developed HACCP plans are currently available at http://www.haccp-nrm.org/ and could be considered useful tools and resources for evaluating activities and sharing protocols at Palmyra Atoll.

\section{(G1-03) Eradicate Incipient Invasive Species}

Stabilize biotic communities to minimize and prevent new and expanding infestations of existing incipient invasive species.

Strategy (G1-O3-S1).-Develop contingency planning. A prevention plan does not ensure nonnative species will no longer be introduced. Contingency plans should be developed for when nonnative species are detected. Although the development of specific contingency plans may be necessary for particular non-native species, some general considerations for contingency planning should be developed. Plans should be developed for currently known incipient invasive species. Plans should commence as necessary.

Task (G1-O3-S1-T1).- - Develop a general contingency plan strategy that includes

- Establishing and maintaining interagency relationships and communication channels, and identifying responsibilities. This should include a mechanism for streamlining permits and permissions needed to carry out protocols particularly when incipient invaders are detected.

- Establishing a mechanism for assessing risk and the cost/benefit of control or eradication.

- Collecting identification of and contact information for sources of scientific advice.

- Identifying reliable short-term funding mechanisms.

- Researching potential intra-organization expertise and (or) service providers.

- Adopting, modifying, collaborating on, or developing pest-specific contingency response protocols, particularly for key unwanted species [e.g., brown tree snakes (Hawai i Department of Agriculture, 2008), West Nile Virus (West Nile Prevention Group, 2003), Pacific Ant Prevention Plan (Pacific Invasive Ant Group, 2004)].

Task (G1-O3-S1-T2).- - Implement incipient invasive species eradication. For example, feral cats have been observed opportunistically during various research and monitoring activities. Develop eradication plan; approve and implement cat eradication.

Task Status. - A potential protocol can be easily developed; for example, using game cameras, traps, and potentially Tylenol ${ }^{\circledR}$ soaked baits (P. Biley, The Nature Conservancy, oral commun., 2008). As with all eradication programs, effects on non-target species must be considered. 
(G1-04) Eradicate or Control the Spread of Established Non-Native and (or) Invasive Species.

Develop plans and protocols to contain and reduce the extent and impact of invasive species currently at Palmyra Atoll.

Strategy (G1-O4-S1).- - Decrease the number of invasive species or the total area of invasive species coverage, and where possible, eradicate invasive species in terrestrial and marine ecosystems. Research and implement methods to mitigate threats from invasive species.

Task (G1-O4-S1-T1). - Prioritize currently established non-native and (or) invasive species for eradication or control. Daehler and others (2004) tested a modified version of the weed risk assessment used in Australia and New Zealand. This assessment uses information from outside Hawai $i$ to predict the behavior ("pest" or "not a pest") of about 200 plant species introduced to Hawai $i$ and other Pacific Islands. Daehler and others (2004) used outside expert opinion to test the screening system and found it accurately identified $95 \%$ of major pests and $85 \%$ of nonpests. They determined that this screening process is an objective, rapid, and cost-effective means of identifying high-risk species. It could be used in horticulture and forestry to reduce future pest plants, while allowing entry of most non-pests. This system also could be adapted and used as a first step to evaluate the risk of non-native species currently on Palmyra Atoll in order to prioritize further eradication and control efforts.

Task (G1-O4-S1-T2).-Develop eradication or control plan strategies for priority established non-native and (or) invasive species that do not yet have plans.

Task (G1-O4-S1-T3). - Continue development and implementation of eradication plans for identified terrestrial ecosystem priority species, such as the rat eradication plan.

Task Status. - Plans to eradicate rats from Palmyra Atoll are currently in development through collaboration of Island Conservation, TNC, and USFWS.

Task (G1-O4-S1-T4)._Continue development and implementation of priority nonnative/invasive marine species plans.

Task Status. - Continue development and implementation of corallimorph control. Work and others (2008) makes recommendations for strategies and proposes to test possible methods.

Task (G1-O4-S1-T5). - Prioritize, develop, and implement identified priority non-native terrestrial plant species plans.

Task Status. - Of the non-native and (or) invasive plant species currently known to be present on Palmyra Atoll, the most invasive are likely Cocos nucifera, Leucaena leucocephala, Epipremnum pinnatum, Casuarina equisetifolia, Shefflera actinophylla, Terminalia catappa, Coccoloba uvifera, Calophyllum inophyllum, and Hibiscus tiliaceus. As suggested by Pat Biley (2007) and in discussion with the USFWS in 2008, these species in particular should be considered for various levels of management. For example, developing management plans for suppression or reduction of mass [Cocos nucifera, Epipremnum pinnatum, Hibiscus tiliaceus are good candidates for this (a draft Coconut Control Plan has been under development)], for containment (Terminalia catappa, Coccoloba uvifera, Calophyllum inophyllum) and for eradication (Leucaena leucocephala, Casuarina equisetifolia, Shefflera actinophylla); groupings here are as suggested by Pat Biley, TNC. An eradication plan was developed for Leucaena leucocephala (author and date unknown), but it 
appears that the plan was not carried out to completion. No documentation of the progress could be located.

(G1-05) Support, Promote, and Coordinate Research and Monitoring that Increases the Understanding of Non-Native and Invasive Species at Palmyra Atoll and Improves Non-Native Species Management Decision Making

There are many outstanding questions regarding the role non-native species are playing in the ecosystems at Palmyra Atoll and what techniques should be implemented for their prevention, detection, control, and eradication. Research designed to answer these types of questions is critical for developing efficient and cost effective management.

Strategy (G1-O5-S1).- - Identify priority research needs for prevention, detection, control, eradication, and evaluation of technique effectiveness and impacts to environment.

Task (G1-O5-S1-T1). - Prioritize research needs.

Task Status. - There appears to be agreement that the eradication/control plans for rat eradication, coconut control, and corallimorph control are priorities. Additional development and prioritization of research needs should continue.

Task (G1-O5-S1-T2). - Collaborate, conduct, and support research on and monitoring of the effects of non-native species.

Task Status. - In addition to ongoing research relevant to developing successful eradication (rat) and control (coconut, corallimorph) plans, research assessing current effects of these species has continued, and further research into designing relevant monitoring programs to assess success and impacts of management actions is a priority currently being assessed.

\section{(G1-06) Educate to Ensure Awareness of Threats and Protocols}

Strategy (G1-O6-S1).-Persons involved with provisioning or shipping goods to Palmyra Atoll as well as visitors, especially staff, traveling to Palmyra Atoll may have some awareness about the importance of biosecurity. However, this awareness needs to be clear and biosecurity guidelines for Palmyra Atoll need to be very specific. The target group includes persons responsible for oversight of, as well as those directly responsible for, supplying and (or) packing items and the vehicles destined for Palmyra Atoll, and anyone going ashore or within $22 \mathrm{~km}$ of shore (e.g., TNC Palmyra Program staff, businesses involved with transporting people and freight, scientists, and recreational visitors).

Task (G1-O6-S1-T1).—Develop a communications strategy for Palmyra Atoll.

Task Status.-Communications strategies for Palmyra Atoll have begun to be developed (see appendix 10, Draft Communications Strategy Components for Awareness of NonNative/Invasive Species at Palmyra Atoll).

Task (G1-O6-S1-T2). - Develop education materials explaining the benefits of prevention.

Task (G1-O6-S1-T3). - Train staff to be aware of and recognize threats/risks and solutions, as well as participate in the implementation and enforcement of preventive protocols. In developing this biosecurity plan, it is clear that staff involved with shipping, handling of freight, and management of Palmyra Atoll both in Honolulu and on the atoll will play a key role in protecting Palmyra from new non-native species introductions and spread. These individuals are 
ideally located to inspect, advise, treat, and report on biosecurity issues. Currently (2010), the level of biosecurity awareness and implementation is variable, and a base level of training about non-native and invasive species and biosecurity/quarantine inspection should be a priority.

Task (G1-O6-S1-T4). - Support a coordinated Palmyra Atoll invasive species public outreach program with shared resources and responsibilities among cooperating entities.

\section{Goal (G2) Monitor New Risk Factors-Develop Ongoing Assessment}

Identify priority risk factors (terrestrial and marine species) that might threaten the Palmyra Atoll system and continue to track changing risk factors over time as potential sources are changing (e.g., Honolulu, Kiritimati).

\section{Desired Future Conditions}

Develop consistent updating procedures and active working relationships with key entities at the state to international levels (e.g., Hawai $i$ to Kiribati) to share information and identify and control threats.

\section{Goal (G2) Objectives}

\section{(G2-01) Adaptive Management Audit and Review}

Nearly all proposed measures outlined in a biosecurity plan need wide cooperation and agreement to be effective. Changes to current behavior in order to deal with biosecurity risk will require acceptance and compromise. An effective system will rely on self-regulation, a form of quality management system. An adaptive management process of audit and review should be developed to ensure implementation and efficacy and to identify improvements that should be made. The review process also will provide the opportunity to document procedures, maintain momentum, and provide ongoing training for those involved in biosecurity, as well as applying new information to updating the plan and procedures.

Strategy (G2-O1-S1). - Establish an adaptive management review process for proposed and implemented biosecurity measures.

Task (G2-O1-S1-T1). - Establish an audit and review team, clearly defining roles and responsibilities.

Task (G2-O1-S1-T2).--Require documentation of biosecurity decisions, protocols, implementation, results, and modifications.

Task (G2-O1-S1-T3).-Conduct an annual audit and review documentation of biosecurity measures and results.

Task (G2-O1-S1-T4).- Incorporate results of audit and review into plan updates and implementation. 


\section{(G2-02) Identify Priority Risks}

Evaluate priority potential risk species in source sites for invasion into Palmyra Atoll. Assess potential invasion routes.

Strategy (G2-O2-S1). - It has already been established that there is the potential for the introduction of additional non-native species. Although prevention is a key element in biosecurity, it also is important to be aware of and prioritize the most likely potential non-native and (or) invasive species introductions. This requires an evaluation of the most likely sources for non-native species introductions and which species pose the greatest risk.

Task (G2-O2-S1-T1). - Identify the most likely sources for non-native species introductions. Aircraft flights, cargo deliveries, and visiting vessels, especially those with passengers and global suppliers, are all potential pathways for the introduction of potentially invasive non-native species from other locations. However, the most likely sources for introductions are the Hawai ian and Line Islands, primarily because of the magnitude of traffic coming from those locations to Palmyra Atoll.

Task (G2-O2-S1-T2). - The weed risk assessment process developed by Daehler and others (2004) mentioned in Task (G1-O4-S1-T1) also can be used to assess species that have the most potential to be newly introduced or to be continually introduced from source areas and that have detrimental effects.

Task Status.- - Although this risk assessment process has not been formally undertaken, most species from Hawai i have the potential to be introduced to Palmyra Atoll. Holt (1996) reported that an estimated 20 non-native invertebrate species became established in Hawai $i$ every year. Eldredge (2000) reported that 5,047 out of 23,150 (22\%) of the species found in Hawai i were non-native. A recent report from cargo inspections at Kahauli airport revealed an average of one new insect arriving in Hawai $i$ every day and one new pathogen arriving nearly every week (Hawai i Department of Agriculture, 2002). These findings indicate the potential for some of these species to make it to Palmyra Atoll and become established without or in spite of preventive measures. Therefore, it is wise to keep informed of nonnative species arrivals at locations likely to be sources for Palmyra Atoll and assess the risk associated with the possibility that they may become introduced. The recently released draft management plan for the Papahānaumokuākea Marine National Monument described the golden crownbeard (Verbesina encelioides) as one of the most worrisome non-native plant species with potential to spread across the Monument. (U.S. Fish and Wildlife Service and others, 2008). This species is present on several of the Hawai ian Islands, and there is potential for this species to get to Palmyra Atoll (Mitchell and others, 2005; Feenstra and Clements 2008; U.S. Fish and Wildlife and others, 2008). Other non-native species from these locations include Cenchrus echinatus and Sporobolus pyramidatus (Flint and Rehkemper, 2002; U.S. Fish and Wildlife and others, 2008). These species all have the potential to compete with native plant species and reduce migratory bird habitat. The most likely pathways for introduction of these and other plant species are seed transfer from a visitor's clothing, baggage, and equipment. Likewise, the current aircraft and barge charters are known to stop at locations such as Midway Atoll where these non-native species are currently a problem. It is worth noting that it also is possible that these and other non-native species could arrive by other means, such as attached to migratory birds coming from infested sites. 
At least 5 of 19 marine algae species intentionally or passively introduced to Hawai i have become established and dispersed around the Hawai ian Islands and have become ecologically dominant in some locations. They are possibly outcompeting native benthic species and are considered a threat to coral reef ecosystems (Smith and others, 2002 in Department of Lands and Natural Resoures, 2003). Similar to the corallimorph problem at Palmyra Atoll, there have been a few native macroalgae species forming large blooms in Hawai $i$ and causing problems akin to those of non-native invasive species. Eldredge and Carlton (2002) found 287 of 4,099 marine invertebrate species in Hawai i to be non-native (201 are considered introduced and 86 of cryptogenic (unknown) origin). Of these, they report that most were introduced through hull fouling $(74 \%)$, and 248 of these species have become established.

Because non-native species introductions are always a possibility and the potential for them to become invasive is difficult to assess, all non-native species introductions should be preempted if possible. Monitoring plans and techniques for tracking new non-native arrivals still need to be developed. Again, the most likely areas for more frequent monitoring would be those areas often used and accessed. Additional non-native species monitoring should be conducted periodically throughout the atoll and, for efficiency, can be part of long-term terrestrial and marine monitoring programs. Assessing species most likely to be introduced with detrimental effects can be an important step in determining when to further develop contingency plans.

\section{(G2-03) Develop Offsite Controls.}

Evaluate the potential for reduction of non-native species at the offsite source to reduce the potential for priority species to gain access to Palmyra Atoll.

Strategy (G2-O3-S1).- - Develop partnerships with relevant agencies for communication and collaboration opportunities. The establishment of additional invasive species poses such risk to Hawai 'i's native wildlife, ecosystem, economy, and public health that preventive measures continue to be evaluated and established. In addition to general preventive measures, working groups have formed specific to high-priority potential invasive species. A few priority identified threats to Hawai $i$ and other Pacific Islands include West Nile Virus, ants, and the brown treesnake (Boiga irregularis) (Pacific Invasive Ant Group, 2004; Mitchell and others, 2005). Three current working groups include the West Nile Virus Prevention Group, the Pacific Invasive Ant Group, Hawai i Ant Group, and the Brown Tree Snake Rapid Response Team. Because these species could pose significant risks if they were to reach Palmyra Atoll, it would be prudent to foster partnerships with these and other relevant groups to incorporate relevant protocols and contribute to security strategies for Palmyra Atoll focusing on reducing non-native species at known sources.

The West Nile Virus Prevention Group is composed of a broad coalition of government agencies and nongovernmental organizations, including the State Department of Agriculture, the Department of Land and Natural Resources (DLNR), the Department of Health (HDOH), U.S. Department of Agriculture (USDA), the Department of the Interior's U.S. Fish and Wildlife Service (USFWS) and U.S. Geological Survey (USGS) Biological Resources Discipline, the U.S. Postal Service; University of Hawai $i$, the Hawai ian Humane Society, the Honolulu Zoo, Ducks Unlimited, and the Nature Conservancy of Hawai'i. The West Nile Virus Prevention Group has developed a plan to respond to, track, and limit the spread of West Nile virus in Hawai $i$. 
The Hawai i Ant Group (HAG) was formed to develop a better understanding of ants and their impacts in Hawai $i$ as well as to facilitate information exchange, monitor and report new introductions, and increase public awareness. HAG recently completed a revised plan for the prevention of the establishment of new ant species, focusing on the red imported fire and little fire ant (Hawai'i Ant Group, 2007). This work will be carried out in collaboration with the HDOA, the ISCs, and the USDA, including the Department of Homeland Security, and the National Park Service.

A multi-agency Brown Tree Snake Rapid Response Team has been formed to address potential brown tree snake sightings in Hawai i. Members travel to Guam for regular training in how to search for and capture brown tree snakes, as one method to prevent the establishment of this animal. HDOA has developed a Detector Dog Program to inspect almost $100 \%$ of military and civilian flights from Guam and The Hawai i Brown Treesnake Response Protocol to educate the public and encourage snake sighting reporting (Hawai i Department of Agriculture, 2008). Other potential introduced species, such as the Africanized honey bee, biting flies, and various marine organisms, pose such high risk of damage that similar preventive planning is needed (Mitchell and others, 2005). As these plans are developed and refined, they should be considered for additions to Palmyra Atoll biosecurity planning.

Task (G2-O3-S1-T1).- Identify and develop important partnerships with groups that have policy development and implementation and non-native species expertise. There are many valuable resources worldwide.

Task Status.- Many potential partners are currently involved in the West Nile Prevention Group, Hawai i Ant Group, and Brown Tree Snake Rapid Response Team noted above. Others include the Aquatic Nuisance Species (ANS) Task Force, the U.S. Department of Agriculture's Animal Health Inspection Service (APHIS), the USFWS, the USGS Biological Resources Discipline, the Hawai i Department of Agriculture, the Department of Land and Natural Resources, the Department of Health, ISCs, the Coordinating Group on Alien Pest Species (CGAPS), the University of Hawai $i$, and the Bishop Museum. Regionally, the South Pacific Regional Environmental Program (SPREP) is an organization with 21 member countries that has been developed to promote cooperation in the Pacific islands region to protect the environment by focusing on ecosystem integrity and ensuring sustainable development. The Secretariat of the Pacific Community (SPC) provides technical assistance, policy advice, and training and research services in areas such as health, human development, agriculture, forestry, and fisheries to Pacific island countries. The New Zealand Ministry of Agriculture and Forestry (MAF) and Australian Quarantine and Inspection Service (AQIS) are leaders in biosecurity information, quarantine protocols, and guidelines and provide excellent resources and expertise. An International group included as part of the Species Survival Commission of the International Union for Conservation of Nature (IUCN/SSC) is the Invasive Species Specialist Group (ISSG) consisting of a global group of experts on invasive species. In addition, the Global Invasive Species Program (GISP) is coordinated by the Scientific Committee on Problems of the Environment in conjunction with IUCN, the Centre for Agricultural Bioscience International (CABI), and the United Nations Environment Program (UNEP), whose goal is to enable local to multinational communities to have access to the best available tools for improving pest prevention and control systems and to identify priorities for new tool development through global cooperation. Websites for some of these and additional organizations include the following: 
ANS Task Force http://www.anstaskforce.gov/default.php

APHIS http:/www.aphis.usda.gov/

USFWS (specifically Pacific Islands) http://www.fws.gov/pacificislands/

http://www.fws.gov/kingmanreef/index.html, http://www.fws.gov/palmyraatoll/index.html

USGS (specifically Biology Discipline) http://biology.usgs.gov/

DLNR http://Hawaii.gov/dlnr/

HDOA http://Hawaii.gov/hdoa

ISCs and CGAPS http://www.Hawaiiinvasivespecies.org/

Bishop Museum http://www.bishopmuseum.org/

University of Hawai i (Pacific Cooperative Studies Unit, various departments)

http://www.Hawaii.edu/

SPREP http://www.sprep.org/

SPC

http://www.spc.int/corp/index.php?option $=$ com_content\&task=view\&id $=14 \& I t e m i d=40$

MAF http://www.maf.govt.nz/mafnet/index.htm

AQIS http://www.daffa.gov.au/aqis

ISSG http://www.issg.org/index.html

TNC http://tncinvasives.ucdavis.edu/

Task (G2-O3-S1-T2).- Support implementation of Hawai' i’s Wildlife Conservation Strategy (see Mitchell and others, 2005).

Task (G2-O3-S1-T3). - Support implementation of Hawai'i‘s Aquatic Invasive Species Management Plan (see Department of Lands and Natural Resources, 2003).

Task (G2-O3-S1-T4).- - Identify and review maintained lists and information regarding nonnative and invasive species with special attention to those with greatest potential threat to Palmyra Atoll terrestrial and marine ecosystem health in order to prioritize species to focus on for collaborative offsite reduction.

Task Status. - There are many valuable resources worldwide. For example, the Hawai ian Ecosystems at Risk project (HEAR) provides invasive species information, technology, and methods to help support effective science based management. PestNet is an e-mail network that provides advice and information on plant protection, including identification and management of plant pests (such as insects, pathogens, and weeds), gives information directly on their websites, answers questions, and notifies subscribers of new incursions through e-mail. Aliens-L is a list serve through ISSG that provides a forum to seek and share information focusing on those non-native species that threaten biodiversity. Many of these resources are available online, including the following: 
ISSG Global Invasive Species Database http://www.issg.org/database/welcome/

USDA National Invasive Species Information Center

http://www.invasivespeciesinfo.gov/index.shtml

USGS Pacific Basin Information Node http://pbin.nbii.gov/

HEAR http://www.hear.org/

Invasive and Exotic Species (information and images) http://www.invasive.org/

Pacific Invasives Learning Network (PILN) http://www.sprep.org/PILN/Index.htm

Pacific Islands Pest List Database http://wwwx.spc.int:8088//pld/index.jsp

PestNet http://www.pestnet.org/

Aliens-L http://www.issg.org/about.htm\#networking

TNC Global Invasive Species Team http://tncinvasives.ucdavis.edu/

\section{Potential Workplan}

\section{Phase 1}

\section{General:}

- Identify responsible parties to continue development and implementation of plan.

- Initiate additional approved quarantine procedures.

- Refine biosecurity document.

- Refine risk factors from nearby Line Islands (particularly Kiritimati).

- Continue developing strategies for objectives.

- Develop monitoring plans for threats and management actions.

- Build teams for evaluation, review, updating, and implementation.

- Build data-quality assurance, data management, and analysis and reporting strategies.

- Develop an adaptive management feedback loop process.

- Prioritize control and eradication plans (e.g., invasive plant removal).

- Acquire funding.

- Implement other approved tasks of plan.

\section{Potential Examples:}

- Experimentally reduce or remove invasive species (e.g., coconut control management).

- Monitor responses to threats and management (e.g., monitoring response to coconut control management).

- Continue efforts to develop stepdown plans to design and implement rat eradication, including developing monitoring plans for plant and wildlife response and collecting baseline information for documenting status and trends.

- Continue to inventory and map non-native species distributions.

- Implement non-native plant species removal plans (e.g., revisit the plan drafted for Leucaena leucocephala).

- Develop and implement plan for corallimorph control. 


\section{Phase 2}

\section{General:}

- Review Phase 1 work and adapt workplan as necessary through evaluation of activities and results from work completed.

- Continue implementation of approved pieces of plan.

\section{Potential Examples:}

- Continue coconut control and revise as necessary based on results.

- Monitor corallimorph site.

- Refine and update status and trends questions.

- Document trends in forest stand composition, such as native plant recruitment with time since coconut (repeat for rat) removal.

- Document the abundance or proportion of trees harboring scale, a pest considered to play a role in severely reducing tree health and potentially causing death.

- Document trends in coral reef composition, native recruitment with time since corallimorph removal.

\section{References Cited}

Aquatic Nuisance Species Task Force, 2000, Guidance for state and interstate aquatic nuisance species management plans, $37 \mathrm{p}$.

Biley, Pat, 2007, Report on Palmyra visit Oct 29-Nov 5, 2007: Honolulu, Hawai i, The Nature Conservancy, $4 \mathrm{p}$.

Brainard, Rusty, Maragos, Jim, Schroeder, Robert, Kenyon, Jean, Vroom, Peter, Godwin, Scott, Hoeke, Ronald, Aeby, Greta, Moffitt, Russell, Lammers, Marc, Gove, Jamison, Timmers, Molly, Holzwarth, Stephani, and Kolinski, Steve , 2005, The state of coral reef ecosystems of the U.S. Pacific remote island areas, in Waddell, J., ed.. The State of Coral Reef Ecosystems of the United States and Pacific Freely Associated States,NOAA Technical Memorandum NOS NCCOS 11. NOAA/NCCOS: Silver Spring, Md., Center for Coastal Monitoring and Assessment's Biogeography Team, p. 338-372.

Buckelew, Stacey, Howald, G. R., Wegmann, Alex, Sheppard, Jacob, Curl, Jennifer, McClelland, Pete, Tershy, Bernie, Swift, Katie, Campbell, Earl, and Flint, Beth, 2005, Progress in Palmyra Atoll restoration: Rat eradication trial, 2005: Report to U.S. Fish and Wildlife Service. Island Conservation, Santa Cruz, Calif., 50 p.

Christensen, N. L., Bartuska, A. M., Brown, J. H., Carpenter, Stephen, D’Antonio, Carla, Francis, Robert, Franklin, J. F., Mac Mahon, J. A., Noss, R. F., Parsons, D. J., Peterson, C. H., Turner, M. G., and Woodmansee, R. G., 1996, The report of the Ecological Society of America Committee on the scientific basis for ecosystem management: Ecological Applications, v. 6, no. 3, p. 665-691.

Daehler, C. C., Denslow, J. S., Ansari, Shahin, and Kuo, Huang-chi, 2004, A risk-assessment system for screening out invasive pest plants from Hawai i and other Pacific Islands: Conservation Biology, v. 18 , no. 2 , p. 360-368.

Dawson, E. Y., 1959, Changes in Palmyra Atoll and its vegetation through the activities of man, 19131958: Pacific Naturalist, v. 1, no. 2, p. 1-51.

Department of Lands and Natural Resources, State of Hawai i, 2003, State of Hawai i aquatic invasive species management plan: Honolulu, HI, Division of Aquatic Resources, 205 p.

Department of the Interior, Office of Insular Affairs, 2006, Palmyra Atoll: Accessible at http://www.doi.gov/oia/Islandpages/palmyrapage.htm. 
Depkin, C. D., 2002, Trip report to Palmyra Atoll, 06 August 2001-07 October 2002: Honolulu, Hawai i, U.S. Fish and Wildlife Service, 133 p.

Eldredge, L. G., 2000, Numbers of Hawai ian species. Supplement 5: Bishop Museum Occasional Papers, v. 63, p. 308.

Eldredge, L. G., and Carlton, J. T., 2002, Hawai ian marine bioinvasions: A preliminary assessment: Pacific Science, v. 56, no. 2, p. 211-212.

Engilis, Jr., Andrew and Naughton, Maura, 2004, U.S. Pacific Islands regional shorebird conservation plan. U.S. Shorebird Conservation Plan: Portland, Oregon, U.S. Department of the Interior, Fish and Wildlife Service, 66 p.

Executive Order 13112, Invasive Species, February 3, 1999: Federal Register, v. 64, no. 25, p. 6183 6186, Accessible at http://www.invasivespeciesinfo.gov/laws/execorder.shtml.

Feenstra, K. R. and Clements, D. R., 2008, Biology and impacts of Pacific island invasive species. 4. Verbesina enceloides, golden crownbeard (Magnoliopsida: Asteraceae): Pacific Science, v. 62, no. 2, p. 161-176.

Fefer, S. I., 1987, Trip report to Palmyra Atoll, 16-30 September 1987: Honolulu, Hawai i, U.S. Fish and Wildlife Service Administrative Report, $31 \mathrm{p}$.

Flint, Elizabeth, Herbst, Derral, McDermond, Ken, Woodside, Dave, and Yuen, Andy, 1992, Survey of the terrestrial biota of Palmyra Atoll 18 February to 9 March 1992: Honolulu, Hawai i, U.S. Fish and Wildlife Service Administrative Report, 19 p.

Flint, Elizabeth. and Rehkemper, Cindy, 2002, Control and eradication of the introduced grass, Cenchrus echinatus, at Laysan Island, Central Pacific Ocean, in Veitch, C. R., and Clout, M. N., 2002, Turning the tide: the eradication of invasive species - Proceedings of the International Conference on the Eradication of Island Invasives: IUCN SSC Invasive Species Specialist Group, IUCN, Gland, Switzerland and Cambridge, UK, p. 110-115.

Freeman, Scott, 2006, Vascular Flora of Palmyra Atoll National Wildlife Refuge: An Update to 1992: Honolulu, Hawai i, U.S. Fish and Wildlife Service Administrative Report, 28 p.

Handler, A. T., Gruner, D. S., Haines, W. P., Lange, M. W., and Kaneshiro, K. Y., 2007, Arthropod surveys on Palmyra Atoll, Line Islands, and insights into the decline of the native tree Pisonia grandis (Nyctaginaceae): Pacific Science, v. 61, no. 4, p. 485-502.

Hawai i Ant Group, 2007, A plan for prevention of establishment of new ant species in Hawai i, with special attention to the red imported fire ant (Solenopsis invicta) and little imported fire ant (Wasmannia auropunctata), $51 \mathrm{p}$.

Hawai i Department of Agriculture, State of Hawai i, Plant Quarantine Division, 2002, Kahului pest risk assessment, $41 \mathrm{p}$.

Hawai i Department of Agriculture, 2008, Stop the brown tree snake brochure, 2 pp.

Herbst, Derral, 1987, Flora and vegetation of Palmyra Atoll: Honolulu, Hawai i, U.S. Fish and Wildlife Service Administrative Report, 37 p.

Herbst, Derral, 1992, Flora and vegetation of Palmyra Atoll: Honolulu, Hawai i, U.S. Fish and Wildlife Service Administrative Report, $28 \mathrm{p}$.

Holt, Alan, 1996, An alliance of biodiversity, agriculture, health, and business interests for improved alien species management in Hawai i: Prepared for the Norway/UN Conference on Alien Species, July 1-5, 1996, 12 p.

Howald, Gregg, Samaniego, Araceli, Buckelew, Stacey, McClelland, Pete, Keitt, Bradford, Wegmann, Alex, Pitt, W. C., Vice, D. S., Campbell, Earl, Swift, Katie, and Barclay, Steve, 2004, Palmyra Atoll rat eradication assessment: Trip report, August 2004: Santa Cruz, CA, Report to U.S. Fish and Wildlife Service, Island Conservation, $61 \mathrm{p}$. 
International Maritime Organization, 1997, The IMO guidelines: Resolution A.868(20): Guidelines for the control and management of ships' ballast water to minimize the transfer of harmful aquatic organisms and pathogens: Accessible at http://globallast.imo.org/index.asp? page=resolution.htm\&menu=true.

International Maritime Organization, 2001, International convention on the control of harmful antifouling systems on ships (AFS): Adopted 5 October 2001: Accessible at

http://www.imo.org/conventions/mainframe.asp?topic_id=529.

Iverson, J. B., 1978, The impact of feral cats and dogs on populations of the West Indian rock iguana, Cyclura carinata: Biological Conservation, v. 14, no. 1, p. 63-73.

Jones H. P., Tershy, B. R., Zaveleta, E. S., Croll, D. A., Keitt, B. S., Finkelstein, M. E., and Howald, G. R., 2008, Severity of the effects of invasive rats on seabirds: A global review: Conservation Biology, v. 22, no. 1, p. 16-26.

Kirkpatrick, R. D., and Rauzon, M. J., 1986, Foods of feral cats Felis catus on Jarvis and Howland Islands, Central Pacific Ocean: Biotropica, v. 18, no. 1, p. 72-75.

Kyle, J. L., and Harris, Eva, 2008, Global spread and persistence of dengue: Annual Review of Microbiology, v. 62, p. 71-92.

Ladeau, S. L., Marra, P. P., Kilpatrick, A. M., and Calder, C. A., 2008, West Nile Virus revisited: Consequences for North American ecology: BioScience, v. 58, no. 10, p. 937-946.

Medina, F. M., and Nogales, Manuel, 2009, A review on the impacts of feral cats (Felis silvestris catus) in the Canary Islands; implications for the conservation of its endangered fauna: Biodiversity and Conservation, v. 18, no. 4, p. 829-846.

Mitchell, Christen, Ogura, Christine, Meadows, Dwayne, Kane, Austin, Strommer, Laurie, Fretz, Scott, Leonard, David, and McClung, Andrew, October 2005, Hawai i's Comprehensive Wildlife Conservation Strategy: Honolulu, Hawai i, Department of Land and Natural Resources, 722 pp. National Invasive Species Council, 2008, 2008-2012 National Invasive Species Management Plan, 35 p. Pacific Invasive Ant Group, 2004, Pacific ant prevention plan, 29 p.

Rock, J. F., 1916, Palmyra Island with a description of its flora: College of Hawai i Publications Bulletin, v. 4, p. 1-53.

Rock, J. F., 1929, The voyage of the Luka to Palmyra Island: Atlantic Monthly, v. 144, no. 9, p. 560566.

Rodriquez, Christina, Torres, Roxana, and Drummond, Hugh, 2006, Eradicating introduced mammals from a forested tropical island: Biological Conservation, v. 130, no. 1, p. 98-105.

Towns, D. R., Atkinson, I. A. E., and Daugherty, C. H., 2006, Have the harmful effects of introduced rats on islands been exaggerated?: Biological Invasions, v. 8, p. 863-891.

U.S. Fish and Wildlife Service, 2001, Conceptual management plan for the proposed Palmyra Atoll National Wildlife Refuge Line Islands, Central Pacific Ocean: Arlington, Virginia, Division of Migratory Bird Management, $99 \mathrm{p}$.

U.S. Fish and Wildlife Service, 2002, Birds of conservation concern 2002.: Honolulu, Hawai i, Pacific Islands Refuge Planning Office, 28 p.

U.S. Fish and Wildlife Service, 2005, Regional Seabird Conservation Plan, Pacific Region: Portland, Oregon, U.S. Fish and Wildlife Service, Migratory Birds and Habitat Programs, Pacific Region, $261 \mathrm{p}$.

U.S. Fish and Wildlife Service, 2006, National Wildlife Refuge System Mission and Goals and Refuge Purposes. $601 \mathrm{FW} \mathrm{1:} \mathrm{Accessible} \mathrm{at} h t t p: / / w w w . f w s . g o v / p o l i c y / 601 \mathrm{fw} 1 . h t m l$.

U.S. Fish and Wildlife Service, 2007, Palmyra Atoll National Wildlife Refuge and Kingman Reef National Wildlife Refuge: Federal Register, v. 72, no. 87, p. 25771-25773. 
U.S. Fish and Wildlife Service, National Oceanic and Atmospheric Administration, and Hawai i Department of Land and Natural Resources, 2008, Draft Papahānaumokuākea Marine National Monument Draft Management Plan 2008: Papahānaumokuākea Marine National Monument, v. 1, $350 \mathrm{p}$.

van Riper III, Charles, van Riper, S. G., and Hansen, W. R., 2002, Epizootiology and effect of avian pox on Hawai ian forest birds: The Auk, v. 119, no. 4, p. 929-942.

Veitch, C. R., and Clout, M. N., 2002, Turning the tide: the eradication of invasive speciesProceedings of the International Conference on the Eradication of Island Invasives: IUCN SSC Invasive Species Specialist Group, IUCN, Gland, Switzerland and Cambridge, UK, 414 p.

Wegmann, Alexander, 2005, Palmyra Atoll National Wildlife Refuge forest type map: Honolulu, Hawai i, U.S. Fish and Wildlife Service.

West Nile Virus Prevention Group, 2003, The West Nile Virus prevention program in Hawai i August 2003 status, $1 \mathrm{p}$.

Williams, G. J., Aeby, G. S., and Davy, S. K., 2008, Coral disease at Palmyra Atoll, a remote reef system in the Central Pacific: Coral Reefs, v. 27, p. 207.

Work T. M., Aeby, G. S., and Maragos, J. E., 2008, Phase shift from a coral to a corallimorphdominated reef associated with a shipwreck on Palmyra Atoll: PLoS ONE, v. 3, no. 8, p. e2989, Accessible at: http://www.plosone.org/article/info:doi\%2F10.1371\%2Fjournal.pone.0002989. 


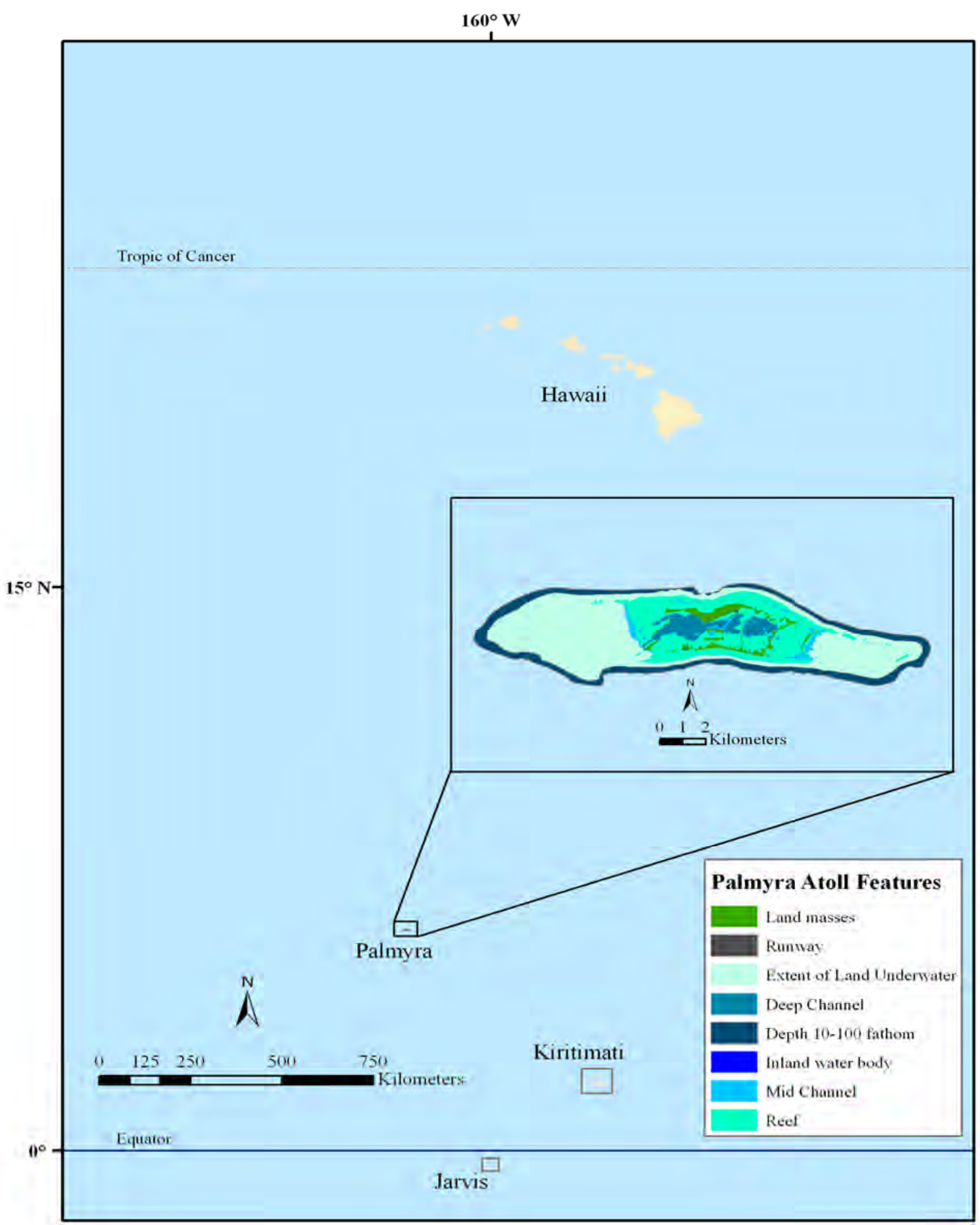

Figure 1. Map of Palmyra Atoll. 
Table 1. Experts consulted regarding Palmyra Atoll management planning.

\begin{tabular}{|c|c|}
\hline Name & Affiliation \\
\hline Lisa Balance & $\begin{array}{l}\text { National Oceanic and Atmospheric Administration } \\
\text { Southwest Fisheries, La Jolla, California }\end{array}$ \\
\hline Steve Barclay & $\begin{array}{l}\text { U.S. Fish and Wildlife Service } \\
\text { Pacific/Remote Islands National Wildlife Refuge Complex, Honolulu, Hawai`i }\end{array}$ \\
\hline Pat Biley & The Nature Conservancy, Maui Program, Honolulu, Hawai`i \\
\hline Chris Depkin & $\begin{array}{l}\text { U.S. Fish and Wildlife Service } \\
\text { Pacific/Remote Islands National Wildlife Refuge Complex, Honolulu, Hawai`i }\end{array}$ \\
\hline Donald Drake & University of Hawai' i, Honolulu, Hawai`i \\
\hline Elizabeth Flint & $\begin{array}{l}\text { U.S. Fish and Wildlife Service } \\
\text { Pacific/Remote Islands National Wildlife Refuge Complex, Honolulu, Hawai`i }\end{array}$ \\
\hline Matthew McKown & University of North Carolina, Chapel Hill, North Carolina \\
\hline Barrie Morgan & The Nature Conservancy, Palmyra Program, Honolulu, Hawai`i \\
\hline Robert Pitman & $\begin{array}{l}\text { National Oceanic and Atmospheric Administration } \\
\text { Southwest Fisheries, La Jolla, California }\end{array}$ \\
\hline Joanna Smith & University of Washington, Seattle, Washington \\
\hline William Smith & $\begin{array}{l}\text { U.S. Fish and Wildlife Service } \\
\text { Pacific/Remote Islands National Wildlife Refuge Complex, Honolulu, Hawai`i }\end{array}$ \\
\hline Alex Wegmann & University of Hawai`i, Honolulu, Hawai`i and Island Conservation \\
\hline Tony Whittaker & Ecological Consultant, Motueka, New Zealand \\
\hline Lee Ann Woodward & $\begin{array}{l}\text { U.S. Fish and Wildlife Service } \\
\text { Pacific/Remote Islands National Wildlife Refuge Complex, Honolulu, Hawai`i }\end{array}$ \\
\hline Hillary Young & Stanford University, Stanford, California \\
\hline
\end{tabular}


Table 2. Terrestrial non-native or invasive plant species identified at Palmyra Atoll.

[The status listed for each species was taken from Freeman (2006). Non-native species reported as no longer occurring at Palmyra Atoll have been grayed out (modified from Herbst, 1992; Freeman, 2006)]

\begin{tabular}{|c|c|}
\hline Species & Status \\
\hline Abelmoschus sp. & non-native \\
\hline $\begin{array}{l}\text { Acalypha wilkesiana } \\
\text { Allium cepa }\end{array}$ & $\begin{array}{l}\text { cultivated ornamental plants no longer occurring } \\
\text { cultivated food plants no longer occurring }\end{array}$ \\
\hline Aloe vera & non-native \\
\hline $\begin{array}{l}\text { Anacardium occidentale } \\
\text { Ananas comosus } \\
\text { Annona sp. }\end{array}$ & $\begin{array}{l}\text { cultivated food plants no longer occurring } \\
\text { cultivated food plants no longer occurring } \\
\text { cultivated food plants no longer occurring }\end{array}$ \\
\hline $\begin{array}{l}\text { Araucaria sp. } \\
\text { Artocarpus altilis }\end{array}$ & $\begin{array}{l}\text { non-native } \\
\text { non-native }\end{array}$ \\
\hline Asparagus sp. & cultivated food plants no longer occurring \\
\hline $\begin{array}{l}\text { Bidens alba } \\
\text { Calophyllum inophyllum }\end{array}$ & $\begin{array}{l}\text { non-native } \\
\text { non-native }\end{array}$ \\
\hline Cannabis indica & cultivated ornamental plants no longer occurring \\
\hline Carica papaya & non-native \\
\hline Casuarina equisetifolia & non-native \\
\hline Cenchrus echinatus & accidental no longer occurring \\
\hline $\begin{array}{l}\text { Chamaesyce hirta } \\
\text { Chamaesyce hypericifolia } \\
\text { Chamaesyce hyssopifolia } \\
\text { Chloris inflata }\end{array}$ & $\begin{array}{l}\text { non-native } \\
\text { non-native } \\
\text { non-native } \\
\text { non-native }\end{array}$ \\
\hline $\begin{array}{l}\text { Citrullus lanatus } \\
\text { Citrus aurantium }\end{array}$ & $\begin{array}{l}\text { cultivated ornamental plants no longer occurring } \\
\text { cultivated food plants no longer occurring }\end{array}$ \\
\hline $\begin{array}{l}\text { Citrus sp. } \\
\text { Coccoloba uvifera } \\
\text { Cocos nucifera }\end{array}$ & $\begin{array}{l}\text { non-native } \\
\text { non-native } \\
\text { potentially non-native }\end{array}$ \\
\hline Codiaeum variegatum var. pictum & cultivated ornamental plants no longer occurring \\
\hline Conyza bonariensis & non-native \\
\hline Cordyline fruticosa & cultivated ornamental plants no longer occurring \\
\hline $\begin{array}{l}\text { Crocus } \\
\text { Crotalaria incana }\end{array}$ & $\begin{array}{l}\text { non-native } \\
\text { non-native }\end{array}$ \\
\hline Cucumus sativus & cultivated food plants no longer occurring \\
\hline Cyperrus rotundus & non-native \\
\hline $\begin{array}{l}\text { Cyperus alternifolius } \\
\text { Cyrtosperma chamissonis }\end{array}$ & $\begin{array}{l}\text { accidental no longer occurring } \\
\text { cultivated ornamental plants no longer occurring }\end{array}$ \\
\hline Digitaria pacifica & non-native \\
\hline Digitaria setigera & non-native \\
\hline Eleusine indica & non-native \\
\hline Emilia sonchifolia & accidental no longer occurring \\
\hline Epipremnum pinnatum & non-native \\
\hline Eragrostis scabriflora & non-native \\
\hline Eragrostis tenella & non-native \\
\hline Erectites hieracifolia & accidental no longer occurring \\
\hline
\end{tabular}


Table 2. Terrestrial non-native or invasive plant species identified at Palmyra Atoll.-Continued

\begin{tabular}{|c|c|}
\hline $\begin{array}{c}\text { Species } \\
\end{array}$ & Status \\
\hline Erythrina variegate var. orientalis & non-native \\
\hline Euphorbia cyanthophora & cultivated ornamental plants no longer occurring \\
\hline Euphorbia pulcherrima & cultivated ornamental plants no longer occurring \\
\hline Graptophyllum pictum & cultivated ornamental plants no longer occurring \\
\hline Hemigraphis reptans & accidental no longer occurring \\
\hline Hibiscus rosa-sinensis & non-native \\
\hline Hibiscus tiliaceus & non-native \\
\hline Ipomoea batatas & non-native \\
\hline Ipomoea pes-caprae ssp. brasiliensis & non-native \\
\hline Kyllinga brevifolia & non-native \\
\hline Leucaena leucocephala & non-native \\
\hline Ludwigia octovalvis & non-native \\
\hline Lycopersicon esculentum & cultivated food plants no longer occurring \\
\hline $\begin{array}{l}\text { Mangifera indica } \\
\text { Mentha } \text { sp. }\end{array}$ & $\begin{array}{l}\text { non-native } \\
\text { non-native }\end{array}$ \\
\hline Morus sp. & cultivated food plants no longer occurring \\
\hline Musa xparadisiaca & non-native \\
\hline Nephrolepis hirsutula & non-native \\
\hline Nothopanax scutellarum & cultivated ornamental plants no longer occurring \\
\hline Ocimum basilicum & non-native \\
\hline Ophioglossum petiolata & accidental no longer occurring \\
\hline Orchid & non-native \\
\hline $\begin{array}{l}\text { Ornamental Glnger } \\
\text { Oxalis corniculata }\end{array}$ & $\begin{array}{l}\text { non-natıve } \\
\text { accidental no longer occurring }\end{array}$ \\
\hline Paspalum fimbriatum & accidental no longer occurring \\
\hline Paspalum orbiculare & non-native \\
\hline Passiflora edulis & cultivated food plants no longer occurring \\
\hline Persea americana & cultivated food plants no longer occurring \\
\hline Phaseolus sp. & cultivated food plants no longer occurring \\
\hline Phoenix sp. & cultivated food plants no longer occurring \\
\hline Phyllanthus amarus & non-native \\
\hline Pilea microphylla & non-native \\
\hline Pluchea carolinensis & non-native \\
\hline Pluchea indica & non-native \\
\hline Pluchea $x$ fosbergii & non-native \\
\hline Plumeria sp. & cultivated ornamental plants no longer occurring \\
\hline Polyscias balfouriana & cultivated ornamental plants no longer occurring \\
\hline Portulaca oleracea & non-native \\
\hline Pseuderanthemum carruthersii & cultivated ornamental plants no longer occurring \\
\hline Pteris ensiformis & non-native \\
\hline Pycreus polystachyos & non-native \\
\hline Raphanus sativus & cultivated food plants no longer occurring \\
\hline Rosa sp. & cultivated ornamental plants no longer occurring \\
\hline Sansevieria trifasciata & cultivated ornamental plants no longer occurring \\
\hline Shefflera actinophylla & non-native \\
\hline Sida rhombifolia & accidental no longer occurring \\
\hline
\end{tabular}


Table 2. Terrestrial non-native or invasive plant species identified at Palmyra Atoll.-Continued

\begin{tabular}{|l|l|}
\hline \multicolumn{1}{|c|}{ Species } & \multicolumn{1}{|c|}{ Status } \\
\hline Spathoglottis plicata & non-native \\
Spermacoce assurgens & non-native \\
Sporobolus indicus & non-native \\
Stachytarpheta jamaicensis & non-native \\
Stachytarpheta urticifolia & non-native \\
Synedrella nodiflora & non-native \\
Syzygium malaccense & cultivated ornamental plants no longer occurring \\
Temptations & non-native \\
Terminalia catappa & non-native \\
Thespesia populnea & cultivated ornamental plants no longer occurring \\
Tridax procumbens & non-native \\
Vernonia cinerea var. parviflora & non-native \\
Viola sp. & cultivated ornamental plants no longer occurring \\
Vitex trifolia & non-native \\
Zea mays & cultivated food plants no longer occurring \\
\hline
\end{tabular}


Table 3. Terrestrial non-native vertebrate species identified at Palmyra Atoll.

\begin{tabular}{|ll|}
\hline \multicolumn{1}{|c|}{ Family/Species } & \multicolumn{1}{c|}{ Status } \\
\hline $\begin{array}{l}\text { Family Canidae (dogs) } \\
\text { Canis familiaris }\end{array}$ & non-native \\
Family Felidae (cats) & \\
Felis catus & non-native \\
Family Suidae (hogs, pigs) & \\
Sus domestica & non-native \\
Family Muridae (mice, rats) & \\
Rattus rattus & non-native \\
Family Phasianidae (pheasants, partridges) & \\
Gallus gallus & non-native \\
Family Sturnidae (starlings) & \\
Acridotheres tristis & non-native \\
Family Gekkonidae (geckos) & \\
Hemidactylus frenatus & non-native \\
Lepidodactylus lugubris & potentially non-native \\
Family Bufonidae (toads) & \\
Bufo marinus &
\end{tabular}


Table 4. Terrestrial native and non-native invertebrate species identified at Palmyra Atoll.

[Taxa: G. sp. indicates undetermined genus and species. The origin listed for each species was modified from Handler and others (2007).]

\begin{tabular}{|c|c|c|}
\hline Order/Family & Taxa & Origin \\
\hline \multicolumn{3}{|l|}{ Order Araneae (spiders) } \\
\hline Agelenidae & Agelenidae G. sp. & Cryptogenic \\
\hline Araneidae & Neoscona theisi (Walckenaer, 1841) & Introduced \\
\hline Heteropodidae & Heteropoda venatoria (Linnaeus, 1767) & Introduced \\
\hline Pholcidae & Smeringopus pallidus (Blackwall, 1856) & Introduced \\
\hline \multirow[t]{8}{*}{ Salticidae } & Hasarius adansoni (Audouin, 1826) & Introduced \\
\hline & Menemerus bivittatus (Dufour, 1831) & Introduced \\
\hline & Messua cf. felix (Peckham and Peckham, 1901) & Introduced \\
\hline & Phintella versicolor (C. L. Koch, 1846) & Cryptogenic \\
\hline & Plexippus paykulli (Audouin, 1826) & Introduced \\
\hline & Salticidae G. sp. 1 & Cryptogenic \\
\hline & Salticidae G. sp. 2 & Cryptogenic \\
\hline & Sandalodes sp. & Cryptogenic \\
\hline \multirow[t]{2}{*}{ Scytodidae } & Scytodes longipes (Lucas, 1845) & Introduced \\
\hline & Scytodes striatipes (L. Koch, 1872) & Introduced \\
\hline Tetragnathidae & Tetragnatha keyserlingi (Simon, 1890) & Native? \\
\hline \multirow[t]{3}{*}{ Theridiidae } & Coleosoma floridanum (Banks, 1900) & Introduced \\
\hline & Latrodectus geometricus (C. L. Koch, 1841) & Introduced \\
\hline & Nesticodes rufipes (Lucas, 1846) & Introduced \\
\hline \multicolumn{3}{|c|}{ Order Blattodea (cockroaches) } \\
\hline Blaberidae & Pycnoscelus indicus (Fabricius, 1775) & Introduced \\
\hline Blatellidae & Supella longipalpa (Fabricius, 1798) & Introduced \\
\hline \multirow[t]{3}{*}{ Blattidae } & Periplaneta americana (Linnaeus, 1758) & Introduced \\
\hline & Periplaneta australasiae (Fabricius, 1775) & Introduced \\
\hline & Platyzosteria soror (Brunner, 1865) & Introduced \\
\hline
\end{tabular}


Table 4. Terrestrial native and non-native invertebrate species identified at Palmyra Atoll.-Continued

\begin{tabular}{|c|c|c|}
\hline Order/Family & Taxa & Origin \\
\hline \multicolumn{3}{|l|}{ Order Coleoptera (beetles) } \\
\hline \multirow[t]{2}{*}{ Anthribidae } & Araecerus vieillardi (Montrouzier, 1860) & Introduced \\
\hline & Mauia subnotatus (Boheman, 1859) & Introduced \\
\hline Carabidae & Carabidae G. sp & Cryptogenic \\
\hline \multirow[t]{2}{*}{ Cerambycidae } & Cerambycidae G. sp. 1 & Cryptogenic \\
\hline & Cerambycidae G. sp. 2 & Cryptogenic \\
\hline \multirow[t]{4}{*}{ Coccinellidae } & Coccinellidae G. sp. & Cryptogenic \\
\hline & Coelophora inaequalis (Fabricius, 1775) & Introduced \\
\hline & Diomus notescens (Blackburn, 1889) & Introduced \\
\hline & Rhyzobius lophanthae (Blaisdell, 1892) & Introduced \\
\hline Cryptophagidae & Toramus(?) sp. & Cryptogenic \\
\hline Cucujidae & Psammoecus insularis (Sharp, 1885) & Introduced \\
\hline \multirow{2}{*}{ Elateridae } & Conoderus pallipes (Eschscholtz, 1829) & Introduced \\
\hline & Melanoxanthus melanocephalus (Fabricius, 1781) & Introduced \\
\hline Hydrophilidae & Dactylosternum abdominale (Fabricius, 1792) & Introduced \\
\hline \multirow[t]{2}{*}{ Ephydridae (continued) } & Placopsidella sp. & Cryptogenic \\
\hline & Scatella stagnalis (Fallen, 1813) & Introduced \\
\hline Hippoboscidae & Olfersia aenescens (Thomson, 1869) & Native? \\
\hline \multirow[t]{2}{*}{ Limoniidae } & Limonia sp. nr. perkinsi (Grimshaw) & Introduced \\
\hline & Styringomyia didyma (Grimshaw, 1901) & Native \\
\hline Lonchaeidae & Lamprolonchaea metatarsata (Kertesz, 1901) & Introduced \\
\hline Milichilidae & Milichiella lacteipennis (Loew, 1865) & Introduced \\
\hline \multirow[t]{4}{*}{ Muscidae } & Atherigona orientalis (Schiner, 1868) & Introduced \\
\hline & Atherigona sp. & Cryptogenic \\
\hline & Musca domestica (Linnaeus, 1758) & Introduced \\
\hline & Muscidae G. sp. & Cryptogenic \\
\hline Phoridae & Chonocephalus sp. & Cryptogenic \\
\hline Platystomatidae & Scholastes lonchifera (Hendel, 1914) & Introduced \\
\hline \multirow[t]{4}{*}{ Sarcophagidae } & Parasarcophaga misera (Walker) & Introduced \\
\hline & Parasarcophaga sp. & Cryptogenic \\
\hline & Sarcophaga peregrina (Robineau-Desvoidy, 1830) & Introduced \\
\hline & Sarcophagidae G. sp. & Cryptogenic \\
\hline Sciaridae & Sciaridae G. sp. & Cryptogenic \\
\hline Stratiomyidae & Cephalochrysa maxima (Bezzi, 1928) & Introduced \\
\hline \multirow[t]{3}{*}{ Syrphidae } & Eristalinus arvorum (Fabricius, 1787) & Introduced \\
\hline & Simosyrphus grandicornis (Macquart, 1842) & Introduced \\
\hline & Syritta $\mathrm{sp}$ & Cryptogenic \\
\hline \multirow[t]{2}{*}{ Tethinidae } & Dasyrhicnoessa insularis (Aldrich, 1931) & Native? \\
\hline & Tethina sp. & Cryptogenic \\
\hline Ulididae & Ulididae G. sp. & Cryptogenic \\
\hline
\end{tabular}


Table 4. Terrestrial native and non-native invertebrate species identified at Palmyra Atoll.-Continued

\begin{tabular}{|c|c|c|}
\hline Order/Family & Taxa & Origin \\
\hline \multicolumn{3}{|c|}{ Order Hemiptera (Heteroptera) (true bugs) } \\
\hline Cynidae & Geotomus pygmaeus (Dallas, 1851) & Introduced \\
\hline Gerridae & Halobates micans (Eschscholz, 1822) & Native \\
\hline \multirow[t]{2}{*}{ Miridae } & Miridae G. sp. & Cryptogenic \\
\hline & Trigonotylus brevipes (Jakovlev, 1880) & Native? \\
\hline Reduviidae & Reduviidae G. sp. & Cryptogenic \\
\hline \multicolumn{3}{|c|}{ Order Hemiptera (Sternorrhyncha) (aphids, whiteflies, scale insects) } \\
\hline Aleyrodidae & Aleyrodidae G. sp. & Introduced \\
\hline Aphididae & Aphididae G. sp. & Cryptogenic \\
\hline Coccidae & Pulvinaria urbicola (Cockerell and Parrott, 1899) & Introduced \\
\hline Margarodidae & Icerya purchasi (Maskell, 1879) & Introduced \\
\hline \multirow[t]{4}{*}{ Pseudococcidae } & Dysmicoccus brevipes (Cockerell, 1893) & Introduced \\
\hline & Dysmicoccus neobrevipes (Beardsley, 1959) & Introduced \\
\hline & Ferrisia virgata (Cockerell, 1893) & Introduced \\
\hline & Planococcus citri (Risso, 1813) & Introduced \\
\hline \multicolumn{3}{|c|}{ Order Hymenoptera (ants, bees, wasps) } \\
\hline \multirow[t]{2}{*}{ Aphelinidae } & Coccophagus ceroplastae (Howard, 1895) & Introduced \\
\hline & Euryischomyia flavithorax (Girault and Dodd, 1915) & Introduced \\
\hline Cynipidae & Kleidotoma sp. & Cryptogenic \\
\hline Diapriidae & Trichopria sp. & Cryptogenic \\
\hline Encyrtidae & Metaphycus flavus (Howard, 1881) & Introduced \\
\hline \multirow[t]{2}{*}{ Eulophidae } & Aprostocetus hagenowii (Ratzeburg, 1852) & Introduced \\
\hline & Hemiptarsenus semialbiclavus (Girault, 1916) & Introduced \\
\hline Evaniidae & Evania appendigaster (Linnaeus, 1758) & Introduced \\
\hline \multirow[t]{10}{*}{ Formicidae } & Cardiocondyla emeryi (Forel, 1881) & Introduced \\
\hline & Cardiocondyla minutior (Forel) & Introduced \\
\hline & Hypoponera punctatissima (Roger, 1859) & Introduced \\
\hline & Monomorium floricola ( Jerdon, 1851) & Introduced \\
\hline & Paratrechina bourbonica (Forel, 1886) & Introduced \\
\hline & Paratrechina longicornis (Latreille, 1802) & Introduced \\
\hline & Paratrechina vaga (Forel, 1901) & Introduced \\
\hline & Pheidole megacephala (Fabricius, 1793) & Introduced \\
\hline & Tapinoma melanocephalum (Fabricius, 1793) & Introduced \\
\hline & Tetramorium bicarinatum (Nylander, 1847) & Introduced \\
\hline \multirow[t]{2}{*}{ Megachilidae } & Megachile fullawayi (Cockerell, 1914) & Introduced \\
\hline & Megachile sp. & Cryptogenic \\
\hline Scelionidae & Scelionidae G. sp. & Cryptogenic \\
\hline \multirow[t]{2}{*}{ Sphecidae } & Sceliphron caementarium (Drury, 1770) & Introduced \\
\hline & Sphecidae G. sp. & Cryptogenic \\
\hline \multirow[t]{2}{*}{ Vespidae } & Pachodynerus nasidens (Latreille, 1802) & Introduced \\
\hline & Polistes aurifer (Saussure, 1853) & Introduced \\
\hline
\end{tabular}


Table 4. Terrestrial native and non-native invertebrate species identified at Palmyra Atoll.-Continued

\begin{tabular}{|c|c|c|}
\hline Order/Family & Taxa & Origin \\
\hline \multicolumn{3}{|l|}{ Order Isopoda (pillbugs) } \\
\hline Philosciidae & Australophiloscia societatis (Maccagno, 1932) & Native \\
\hline \multicolumn{3}{|l|}{$\begin{array}{l}\text { Order Lepidoptera (moths, } \\
\text { butterflies) }\end{array}$} \\
\hline Agonoxenidae & Agonoxena argaula (Meyrick, 1921) & Introduced \\
\hline Cosmopterigidae & Anatrachyntis incertulella (Walker, 1864) & Introduced \\
\hline Crambidae & Piletocera signiferalis (Wallengren) & Cryptogenic \\
\hline Gelechiidae & Stoeberhinus testaceus (Butler, 1881) & Introduced \\
\hline Gracillariidae & Gracillariidae G. sp. & Cryptogenic \\
\hline \multirow[t]{2}{*}{ Noctuidae } & Chrysodeixis eriosoma (Doubleday, 1843) & Introduced \\
\hline & Spodoptera litura (Fabricius, 1775) & Introduced \\
\hline Nymphalidae & Hypolimnas bolina (Linnaeus, 1758) & Native? \\
\hline Sphingidae & Agrius cingulata (Fabricius, 1775) & Introduced \\
\hline \multirow[t]{2}{*}{ Tineidae } & Erechthias simulans (Butler, 1882) & Introduced \\
\hline & Opogona sp. & Cryptogenic \\
\hline \multicolumn{3}{|c|}{ Order Odonata (dragonflies, damselflies) } \\
\hline Aeshnidae & Anax junius (Drury, 1770) & Native \\
\hline Coenagrionidae & Ischnura aurora (Brauer, 1865) & Native \\
\hline \multirow[t]{2}{*}{ Libellulidae } & Crocothemis servilia (Drury, 1770) & Introduced \\
\hline & Pantala flavescens (Fabricius, 1770) & Native \\
\hline \multicolumn{3}{|c|}{ Order Orthoptera (grasshoppers, crickets, katydids) } \\
\hline Acrididae & Oxya japonica (Thunberg, 1824) & Introduced \\
\hline \multirow[t]{4}{*}{ Gryllidae } & Cycloptilum sp. & Cryptogenic \\
\hline & Ornebius sp. & Cryptogenic \\
\hline & Speonemobius tigrinus (Saussure) & Native? \\
\hline & Teleogryllus oceanicus (Le Guillou, 1841) & Introduced \\
\hline Pyrgomorphidae & Atractomorpha sinensis (Bolivar, 1905) & Introduced \\
\hline \multirow[t]{2}{*}{ Tettigoniidae } & Conocephalus saltator (Saussure, 1859) & Introduced \\
\hline & Phisis holdhausi (Karny, 1926) & Native \\
\hline
\end{tabular}


Table 5. Marine non-native or invasive species.

\begin{tabular}{|ll|}
\hline \multicolumn{1}{|c|}{ Order/Species } & \multicolumn{1}{c|}{ Status } \\
\hline $\begin{array}{l}\text { Order Corallimorpharia (corallimorphs) } \\
\text { Rhodactis howsei }\end{array}$ & native acting invasively \\
\hline \multicolumn{1}{l}{ Two unknown sponge species } & non-native \\
Unknown algae species & non-native \\
$\begin{array}{l}\text { Order Anthoathecatae (athecate hydroids) } \\
\text { Pennaria disticha }\end{array}$ & \\
$\begin{array}{l}\text { Order Sessilia (sessile barnacles) } \\
\text { Balanus amphitrite amphitrite }\end{array}$ & unknown \\
$\begin{array}{l}\text { Order Enterogona (tunicates) } \\
\text { Diplosoma listerianum }\end{array}$ & unknown \\
\hline
\end{tabular}




\section{Appendix 1. Potential Non-Native Species Introduction Pathways Relevant to Palmyra Atoll}

Aircraft, including contents

- Aircraft cabin

- Wheel wells

- Crew and passengers, including personal gear (clothing, shoes, luggage)

- Luggage and contents -soft gear (e.g., back packs), hard gear (e.g., pelican cases)

- $\quad$ Equipment -soft gear (e.g., wetsuits, nets, notebooks), hard gear (e.g., cameras)

- Food -fresh produce, eggs, meat

- Shipping packaging, corrugated cardboard boxes

Cargo, visiting vessels, or vessels in distress, including contents

- Hull

- Ballast

- Holding or Bait Well

- Decks

- Tender Vessels - particularly if intended to be used at Palmyra Atoll

- Vessel living spaces, including cabins, galley, head, etc.

- Containers and contents

- Vehicles

- Crew and passengers, including personal gear (clothing, shoes, luggage)

- Luggage and contents - soft gear (e.g., back packs), hard gear (e.g., pelican cases)

- Equipment -soft gear (e.g., wetsuits, nets), hard gear (e.g., cameras)

- Food -fresh produce, eggs, meat

\section{Potential Non-Native Species Introduction Pathways for Dispersal after Introduction}

Recreational and Scientific Vessels and Equipment

- 'Open-water' boats and associated equipment (e.g., research boat currently (2010) the 'Zenobia' and rescue boat currently (2010) the 'Apex'), and associated equipment — soft gear (e.g., life vests) and hard gear (e.g., paddle, anchor)

- 'Lagoon' boats and associated equipment—soft gear (e.g., life vests) and hard gear (e.g., paddle, anchor)

- Kayaks and associated equipment — soft gear (e.g., life vests) and hard gear (e.g., paddle, anchor)

- Dive equipment — soft gear (e.g., buoyancy compensator, wetsuit) and hard gear (e.g., fins, snorkels, mask)

- Crew and passengers, including personal gear (clothing, shoes)

- Equipment - soft gear (e.g., backpacks, nets), hard gear (e.g., cameras, traps) 


\section{Appendix 2. Special Conditions and Rules for Visiting and Departing Palmyra Atoll and Moving Intra-Atoll}

The most cost effective and efficient way to reduce non-native species invasions is to prevent their arrival. The Palmyra Atoll Biosecurity Plan focuses on identifying potential risk pathways and enhancing current strategies to prevent non-native species from being introduced and if introduced, preventing their spread across the atoll. The pathways that are addressed are all human related (transportation by air or water, not only the vehicle exteriors and interiors, but also their contents, including passengers) as opposed to pathways related to the species natural dispersal. These and any other biosecurity policies relevant to the use of Palmyra Atoll National Wildlife Refuge should be developed with and approved by the U.S. Fish and Wildlife Service.

These rules are intended to be distributed to visitors as appropriate and relevant prior to their preparation for traveling to Palmyra Atoll and understood, implemented, and enforced by TNC staff. Some protocols such as Additional Special Conditions for Traveling between Islets at Palmyra Atoll National Wildlife Refuge should be reviewed and explained to each relevant visitor by TNC staff upon arrival and posted visibly in appropriate locations (e.g., galley, wet and dry laboratories, snorkel tent, kayak tent, dive building and dock). Although these protocols generally are designed to facilitate the prevention of non-native species from being introduced to Palmyra Atoll, they also apply upon departure to avoid the possibility of (re-) introducing non-native species to other locations, such as Hawai i.

$* * * * * * * * * * * * * * * * * * * * * * * * * * * * * * * * * * * * * * * * * * * * * * * * * * * * * * * * * * * * * * * * * * * * * * * * * * * * * *$

Palmyra Atoll provides habitat for many plants and animals, vulnerable to the introduction of competing or predatory species. Such introductions may cause the extinction of species from the atoll, the modification of species distributions and community structure, and potentially the destruction of entire communities. Notable local examples at Palmyra Atoll include: the introduction of rats (Rattus rattus) possibly having caused the elimination of burrowing seabird colonies and vulnerable plant species; the introduction or enhanced planting of coconuts (Cocos nucifera) that has crowded out native forest and reduced nesting and roosting habitat for most seabirds as well as other taxa; and the introduction and proliferation of numerous ant species throughout the Pacific Islands that have had many negative effects on plant and animal species. For example, non-native ants through tending hemipterans, such as scale, (e.g., Pulvinaria ubicola, which feeds on plants), have led to decreased health of Pisonia grandis.

Although there are a large number of previously established non-native species, the potential for new introductions is high, as is the repeated introduction of existing species. Repeated introduction of non-native species may introduce genetic variability increasing their viability and invasive potential. Careful inspection of all vehicles, materials and containers should be required.

Other Pacific Islands, such as Kure and the "high islands" (Oahu, Hawai 'i, Maui, Kauai, etc.) as well as certain islands within Midway Atoll, Pearl and Hermes Reef and French Frigate Shoals, have plants and (or) animals that are of high risk for introduction to Palmyra Atoll. Ants and various other insect and plant species are of special concern. For example, harmful plant species of concern that are known from Hawai $i$ including the Northwestern Hawai ian Islands and applicable to Palmyra Atoll are Verbesina encelioides, Cenchrus echinatus, and Setaria verticillata. 
The Nature Conservancy and U.S. Fish and Wildlife Service are responsible for the management and protection of the islets, reefs and wildlife of Palmyra Atoll. No one is permitted to set foot within the atoll without their express permission through the permitting process. Due to the aforementioned concerns, the following restrictions on the movement of persons and materials throughout the atoll should be implemented.

\section{The Following Conditions and Rules Apply to All Visitors to Palmyra Atoll}

Useful Definitions:

- "new" means off the shelf and never used anywhere but Palmyra Atoll.

- "clothing" is all apparel, including shoes, socks, over and under garments.

- "soft gear" is all gear, such as daypacks, fanny packs, duffle bags or other soft luggage, packing foam or similar material, camera bags, camera/binocular straps, microphone covers, nets, holding or weighing bags, bedding, tents, luggage, or any fabric, fiber, paper or material capable of harboring spores, seeds or insects, eggs, etc.

- $\quad$ "hard gear" is all other gear, such as pelican cases, cameras, clip boards, binoculars and any other gear that can be wiped cleaned with disinfecting solution (see acceptable disinfection solutions listed below).

1. Any person who will be going on land at Palmyra Atoll should have ideally new, clean (washed and (or) frozen or disinfected just prior to traveling) clothes and shoes, soft gear and hard gear. All must be visually inspected for any visible soil or potentially non-native species, including mold, spores, fungus, seeds, eggs, insects, or other animals, with special attention given to pockets, cuffs, open linings, Velcro®, and shoes (examining all parts of the shoe including soles, tongues, laces, and inside). Clothing and soft gear should be frozen ${ }^{*}$ for 48 hours prior to landing on Palmyra Atoll or soaked in disinfecting solution for at least 10 minutes before washing and drying and packaging in clean luggage or containers (see acceptable disinfection solutions listed below). Hard gear must be thoroughly cleaned, including internal inspection whenever possible, but does not need to be frozen.

Acceptable Disinfection Solutions:

- A 3\% dilution of commercial bleach (e.g., Clorox ${ }^{\circledR}$ or other 5-6\% sodium hypochlorite product) in fresh water.

- The manufacturer's recommended disinfection strength dilution of quaternary ammonium compounds (QAC) in "soft" (low concentration of calcium or magnesium ions) fresh water. An example of an acceptable QAC solution is Lysol® All Purpose Cleaner in a $6.6 \%$ Lysol®: water dilution.

* This rule puts a burden on visitors unlikely to have freezers large enough to accommodate their needs and would still leave the potential for 'hitchhikers' during transit to the air/vessel terminal with at minimum luggage exteriors vulnerable. Another possible solution could be for TNC to provide freezers in Honolulu, so that visitors can pre-ship their luggage in advance so TNC staff can freeze or tarp and fumigate, then seal all equipment (clothes, books, tents, everything) just prior to departure. This procedure could give visitors the option of bringing only a frozen set of clothing/carry on for the departure to Palmyra Atoll or being able to pick up items from TNC at the air/vessel terminal to change into and use. 
2. Pack cleaned and (or) disinfected supplies (including food) and equipment in plastic buckets with fitted lids or other sealable metal or plastic containers because they can be thoroughly cleaned inside and out. Cardboard boxes disintegrate in a short time and harbor seeds, animals, etc., which cannot be easily found or removed. In fact, Crowe (2001) examined the AQIS Pest and Disease Interception Database and found 'hitchhikers' intercepted on various commodities during quarantine including cardboard boxes, Styrofoam ${ }^{\mathrm{TM}}$ boxes, paper, and building materials. Although fumigation is possible for packaging materials, it is better to avoid use of cardboard and similar packaging and fumigate sparingly when necessary, such as for importing paper and building supplies. Wooden packing materials (pallets, crating, boxes) also harbor insects and seeds and should be avoided and only allowed if well constructed (tight fitting seams are required). For wood packaging, inside and outside surfaces must be painted or varnished to provide a smooth, cleanable finish that seals all holes. All wood including building materials must be treated.

Food and cooking items need not be fumigated but should be cleaned and frozen, if freezable. Such equipment can only be packed in wooden crates if treated as described above.

Modified from

U.S. Fish and Wildlife Service, National Oceanic and Atmospheric Administration, and Hawai' $i$ Department of Land and Natural Resources, 2008, Draft Papahānaumokuākea Marine National Monument Draft Management Plan 2008: Papahānaumokuākea Marine National Monument, v. 3, 422 p.

References Cited

Crowe, Bill, 2001, Hitchhikers not on plant material: Exotic Forest Pests Online Symposium: April 1629, 2001, Accessible at: http://www.apsnet.org/online/proceedings/exoticpest/Papers/crowe.htm

\section{Additional Special Conditions for Traveling Between Islets at Palmyra Atoll National Wildlife Refuge:}

Cooper/Menge and Strawn Islets (Cooper Islet complex) are high-use islets thus most exposed to potentially new introductions of non-native species. Cooper/Menge has been documented as harboring the greatest diversity of recorded non-native terrestrial species at Palmyra Atoll. To prevent further spread of non-native and potentially invasive plants and animals from the Cooper Islet complex to the other islets within this atoll, the following precautions must be taken:

1. Every person should have quarantine gear and clothing for the Cooper Islet complex and separate quarantine gear and clothing for all other islets in the atoll. For instance, the same clothing, and if needed camping gear, may be used on all other islets, but anything used at the Cooper Islet complex needs to stay off all other islets in the atoll in the general effort to keep high infestation areas quarantined from low infestation areas. Do not use the outer islet clothing and gear on this complex. To the extent possible, clothing and gear to be used off the Cooper Islet complex should be kept in tight sealed containers between uses and freezing or disinfecting. If it is impossible to have separate sets of gear, disinfection and where appropriate, freezing should take place between all uses. 
2. To avoid transport of soil, microbes, fungus including molds, mildew, and their spores, plant material and seeds, insects, lizards, or other animals and their eggs or cysts from within kayaks or lagoon boats the protocol for Disinfection of Scientific/Recreational Equipment, Dive Gear, and Subsistence or Other Fishing Gear for Prevention of Disease and Introduced Species should be followed. Briefly, this includes carefully inspecting kayaks, lagoon boats, and safety boats, as well as any other vessels and associated equipment (life vests, anchors and lines, engine, seats, cushions, storage compartments, and stored equipment) used within the lagoon. In addition, requirements include inspection of any supplies or equipment going ashore, removal of visible 'contamination', and if necessary, hosing down/disinfecting equipment before departing the Cooper Islet complex and when traveling between islets.

Procedures modified from

U.S. Fish and Wildlife Service, National Oceanic and Atmospheric Administration, and Hawai i Department of Land and Natural Resources, 2008, Draft Papahānaumokuākea Marine National Monument Draft Management Plan 2008: Papahānaumokuākea Marine National Monument, v. 3, 422 p. 


\section{Appendix 3. Additional Special Conditions for Food Provisions Destined for Palmyra Atoll}

Careful consideration should be given to the decision to continue allowing some fresh foods, especially produce, to be transported to Palmyra Atoll. Produce, such as fruits and vegetables, especially leafy vegetables and tubers, should be evaluated for the potential to become established. For instance, some tomatoes have the potential to easily establish in a new environment. In addition, produce can act as an introduction vector (e.g., fruit flies), and fresh produce readily available for transport to Palmyra Atoll is unlikely to be previously inspected. Reports from the items that do go through HDOA inspections (2002, and e-News 2004-07) reveal that soil and new non-native species interceptions occur regularly. These interceptions may include fungal diseases, pathogens, arthropods (such as ants, aphids, mealy bugs, white fly), etc. on various produce from artichokes to watercress coming from multiple parts of the world. Any fresh produce permitted on Palmyra Atoll should be inspected for cleanliness, especially those items with the potential for containing soil, which can contain seeds, eggs, larvae, etc. Risk assessments should ultimately be completed with items identified and checked against an approved list of permissible produce. Certain foods that are not considered 'approved', but are known to possibly harbor risk species with only low to no mobility could be permitted on vessels not bringing produce ashore. All other food that can be safely frozen (this does not apply to food in cans or glass jars) should be packaged in air tight containers just as all other gear and frozen for 48 hours.

Procedures modified from

U.S. Fish and Wildlife Service, National Oceanic and Atmospheric Administration, and Hawai 1 Department of Land and Natural Resources, 2008, Draft Papahānaumokuākea Marine National Monument Draft Management Plan 2008: Papahānaumokuākea Marine National Monument, v. 3, 422 p.

References Cited

Hawai i Department of Agriculture, State of Hawai i, Plant Quarantine Division, 2002, Kahului pest risk assessment, $41 \mathrm{p}$.

Hawai i Department of Agriculture, State of Hawai i, Plant Quarantine Division, 2004-2007 e-News, Accessible at: http://Hawaii.gov/hdoa/meetings_reports/e-news/. 


\section{Appendix 4. Conditions and Rules for Air Transport to Palmyra Atoll}

Air Transport

Maritime Air Charters' Gulfstream I aircraft is the main commercial air service currently providing service to Palmyra Atoll from Honolulu. The same company also provides charters to Midway Atoll, Christmas Island, and inter-island flights within the Hawai ian Islands.

Risks associated with aircraft, flight crew, passengers and baggage

International civil aviation appears to be a significant pathway for the unintentional introduction of non-native species of the "hitchhiking" variety (such as micro-organisms, seeds and insects) (International Civil Aviation Organization, 2004). Potential risks include numerous terrestrial nonnative species, such as microbes, fungus including molds, mildew, and their spores, plant material and seeds, snails, insects, frogs, lizards, snakes, rodents or other animals and their eggs or cysts. Aircraft interiors and exteriors, such as cabins, cargo holds, and wheel wells, have the potential to harbor such pests. It is advisable that each aircraft be inspected for unintentional non-native species, such as rats, snakes, lizards, frogs, insects, eggs, and seeds prior to departure. Methyl bromide has been used for fumigation for many years. However, the Montreal Protocol, signed by the United States and 26 other countries in 1987, and currently approved by 191 countries (U.S. Environmental Protection Agency, 2008) has targeted methyl bromide for phasing out due to deleterious effects on the ozone. The EPA cites potential chemical alternatives to methyl bromide which include sulfuryl fluoride and phosphine, as well as contact insecticides and rodenticides. Non-chemical alternatives include controlled atmospheres utilizing nitrogen and carbon dioxide, or heat and cold (U.S. Environmental Protection Agency, 2000). Until more comprehensive alternatives have been approved, air curtains are showing promising results as an alternative to fumigation in preventing flying insects from entering aircraft. As such, air curtains should be considered a preventative measure to be used along with physically clearing the cabin of any insects that have already entered. Aircraft have been known to harbor insects, rodents, and airborne diseases, many of which require specific cleaning procedures to remove. However, no references were found that quantify the risk of aircraft cabins as pathways for soil, seeds, non-flying insects, molds, etc. Vacuuming has been used successfully to collect samples of seeds to investigate potential pathways (Whinam and others, 2005). Vacuuming could serve the dual purpose of reducing potential 'hitchhikers' and creating collections to be used in future research to quantify the risk and prioritize continued or additional measures to prevent new introductions through this potential pathway. The Following Conditions and Rules Apply to Aircraft Planned to Land at Palmyra Atoll Recommendations for aircraft include:

1. Establish an integrated pest management program for aircraft landing at Palmyra Atoll.

2. Between flights to other locations and prior to boarding for flights to Palmyra Atoll, require cleaning/disinfecting of the cabin area, cockpit, wheels, wheel wells, skid/runner bars, under deck plates, panels, in flap wells and all other areas where foreign debris or species may have lodged. Clean personal equipment belonging to crew and pilot.

3. Require inspection of aircraft interior for non-native species and if necessary, removal of any rodents, insects, lizards, and any other animals, plant matter and seeds, fungus, and soil discovered during inspection.

4. Require inspection of wheel wells for potential 'hitchhikers', such as the brown tree snake.

5. Require on site capability to deal with non-native species finds. 
6. Create additional monitoring/surveillance programs for specific non-native species, if required.

Consider:

1. Requiring specific disinfecting procedures, such as vacuuming and(or) fumigation of aircraft cabin to reduce potential for viable non-native species/propagules (including mold, spores, fungus, seeds, eggs, insects, frogs, lizards, snakes, rodents, or other animals and soil, which can harbor non-native species and disease) to be transported to Palmyra Atoll.

2. Use of air curtains to reduce the potential for flying insects to enter cabin once it has been cleared of such pests for boarding prior to departure.

3. Site or cargo treatment if significant or persistent non-native species problems are identified.

Flight crew, passengers, and their baggage can be unintentional pathways for non-native species. The protocol requirements for access to the Northwestern Hawai ian Islands have been modified for use for Palmyra Atoll and should be distributed to all visitors as part of arranging their travel (see Palmyra Atoll Special Conditions and Rules For Visiting and Departing Palmyra Atoll and Moving IntraAtoll). Screening procedures for passengers and their baggage do not currently exist and following protocols is voluntary. Therefore, in addition to providing the protocols, it is important to educate visitors about the risks associated with non-native species. These risks should be emphasized prior to a visit to Palmyra Atoll, and reiterated to all persons leaving the aircraft at Palmyra Atoll. In lieu of formal inspection procedures, it would be advisable to develop a questionnaire that could be filled out by passengers prior to loading baggage, in order to allow any last minute inspections and removal of items likely to be high risk.

Recommendations for TNC personnel, passengers, and flight crew during waiting period prior to boarding aircraft:

1. Complete pre-inspection questionnaire relevant to the biosecurity protocols.

2. Provide clean locations off the ground for baggage to be placed upon arrival to aircraft location and for inspection of any visible 'hitchhikers' (e.g., non-native species/propagules including mold, spores, fungus, seeds, eggs, snails, insects, frogs, lizards, snakes, rodents or other animals and soil, which can harbor non-native species and disease), which can be removed prior to loading.

3. Request that everyone does a last minute check of outer clothing, pockets, cuffs Velcro®, and carry on luggage prior to boarding the aircraft.

4. Provide heavy duty boot and shoe brushes (for last minute cleaning) and clean mats for boarding area.

References Cited

International Civil Aviation Organization, 2004, Report by the council on progress in implementation of A33-18: Preventing the introduction of invasive alien species: Assembly - 35th Session Economic Commission, $6 \mathrm{p}$.

U.S. Environmental Protection Agency, 2000, EPA Methyl Bromide Phase Out Web Site: Accessible at http://mbao.org/mbrqa.html.

U.S. Environmental Protection Agency, 2008, EPA Ozone Layer Depletion -Regulatory Programs Methyl Bromide Questions \& Answers: Accessible at http://epa.gov/spdpublc/mbr/qa.html.

Whinam, J., Chilcott, N., and Bergstrom, D.M., 2005, Subantarctic hitchhikers: expeditioners as vectors for the introduction of alien organisms: Biological Conservation, v., 121, p. 201-219. 


\section{Appendix 5. Conditions and Rules for Shipping Vessels, Containers, and Other Cargo Destined for Palmyra Atoll}

There are an unspecified number of commercial vessels providing shipping service between Honolulu and Palmyra Atoll. Their routes were not specified nor whether they ship specifically to Palmyra Atoll from Honolulu with no prior stops or whether they continue on with additional cargo for subsequent destinations. This missing information should be assembled and documented by The Nature Conservancy (TNC) in order to ensure appropriate biosecurity measures are taken.

\section{Biosecurity Risk Associated with Shipping Vessels:}

Cargo ships appear to be a significant pathway for the unintentional introduction of non-native species of the "hitchhiking" type (especially plant material, seeds, and spider webs) (Whinam and others, 2005). There are various potential non-native species pathways associated with cargo vessels that may pose risks to both terrestrial and marine ecosystems. Terrestrial ecosystem risks associated with shipping include non-native species present within the shipment before loading onto the vessel, those aboard the vessel itself, and those 'hitchhiking' through staff or passengers' clothing or other belongings. These species could enter the near shore and ashore ecosystems of Palmyra Atoll from cargo ships through their own mobility, through transfer by wind or current, or through 'hitchhiking' on cargo or persons going ashore. Some of the potential terrestrial non-native species posing a risk include microbes, fungus including molds, mildew, and their spores, plant material and seeds, snails, insects, frogs, lizards, snakes, and rodents or other animals and their eggs or cysts. These pathway risks could result from inadequately cleaned or treated areas. Shipping containers (inside and out), vessel decks, cargo holds, and other living and storage space have the potential to harbor non-native species. Additionally, marine ecosystems are vulnerable to non-native species introductions through pathways, such as hull fouling, ballast water, anchors, and anchor chains, and tender vessels that may enter the water. Non-native marine species can include organisms, such as bacteria and microscopic algae, barnacles, seaweeds, mollusks, bryozoans, sponges, sea squirts, polychaete worms, sea anemones, and crabs.

It is advisable that cargo ships be inspected for unintentional non-native species aboard. Methyl bromide has been used for fumigation for many years. However, the Montreal Protocol, signed by the United States and 26 other countries in 1987, and currently approved by 191 countries (U.S.

Environmental Protection Agency, 2008) has targeted methyl bromide for phasing out due to deleterious effects on the ozone. The EPA cites potential chemical alternatives to methyl bromide, which include sulfuryl fluoride and phosphine, as well as contact insecticides and rodenticides. Non-chemical alternatives include controlled atmospheres utilizing nitrogen and carbon dioxide, or heat and cold (U.S. Environmental Protection Agency, 2000).

Recommendations for shipping vessels include:

1. Establish integrated pest management programs with vessels used for commercial freight services.

2. Between shipping to other locations and prior to departure for Palmyra Atoll, require thorough cleaning of all decks holding vehicles or equipment that could potentially be contaminated. This process includes cleaning soil from recessed areas of the decks, i.e., clover leafs, pad eyes, and tie-down channels, as well as under shelving, corners and other hard-to-reach areas. Require subsequent inspection of all relevant areas needing specific disinfecting, vacuuming and (or) fumigation to reduce potential for viable non-native 
3. Additional monitoring/surveillance programs for specific non-native species if required.

4. Develop on site capability to deal with non-native species finds.

Consider:

1. Requiring whole ship treatment/fumigation if significant or persistent non-native species problems are identified.

\section{Biosecurity Risk Associated with Freight Consolidation Areas and Containers}

Shipping companies consolidate freight at designated premises and should do so with oversight from TNC. It is common for items to arrive on Palmyra Atoll pre-packed in a box or crate. The contents typically are recorded on the cargo manifest (e.g., personal effects, field station equipment and supplies, science equipment, vehicles and machinery and essentially anything else that cannot be easily transported by air). Various contaminants likely are present in the freight consolidation areas, outer surfaces of containers, and on items unable to fit in containers. These contaminants could include soil harboring non-native species and disease, as well as other potential non-native species, such as fungus including molds, mildew, and their spores, plant material and seeds, snails, insects, frogs, lizards, snakes, and rodents or other animals and their eggs or cysts.

Recommendations for freight consolidation areas include:

1. Require freight consolidation areas to be clean.

2. Require containers to be carefully cleaned inside and out before loading, and consider fumigation prior to sealing the containers.

3. If containers are required to sit loaded for any length of time, the exteriors should be recleaned before loading.

4. Require items unable to fit into shipping containers to be carefully cleaned prior to loading onto vessel.

Consider:

1. Requiring cargo be loaded into suitable containers specifically designated for Palmyra Atoll.

2. Requiring site treatment if significant or persistent non-native species problems are identified.

\section{Biosecurity Risk Associated with Sea Cargo}

With sea transit providing the main freight link to Palmyra Atoll, ship's cargoes contain various items used on the Atoll and constitute a significant biosecurity risk. Attempting to compile a complete list of potential risk cargo and applicable risks probably is not a useful approach, as everything from runway or building materials, machinery to vehicles and vessels and their parts and tools, scientific equipment, and anything from food to fuel may be part of the manifested cargoes. There are, however, some types of freight or risk cargo considered biosecurity risks that have not been addressed in the general Palmyra Atoll visitation requirements (see appendix 2, Special Conditions and Rules for Visiting and Departing Palmyra Atoll and Moving Intra-Atoll and appendix 3, Additional Special Conditions for Food Provisions Destined for Palmyra Atoll). These items should be required to meet some specific quarantine requirements. Vehicles, boats, machinery, building materials, tools, etc. should all be examined carefully. Pressure washing or steam-cleaning, and where relevant, shop-vacuuming 
interiors of vehicles and machinery with particular attention to areas where seed and soil can gather are recommended. For used vehicles, boats, and machinery in particular, more stringent precautions should be taken. Protocols providing more specific guidelines have been provided in appendix 6, Disinfection Standards for Used Vehicle, Machinery Equipment Destined for Palmyra Atoll and appendix 7, Disinfection Protocol for Boats and Trailers Destined for Palmyra Atoll.

Recommendations for cargo include:

1. Require cargo be inspected for soil, mold, spores, fungus, plant material, seeds, eggs, snails, insects, frogs, lizards, snakes, rodents or other animals and cleaned prior to packing into sealed plastic containers.

2. Require packing cleaned and (or) disinfected supplies (including food) and equipment in plastic buckets with fitted lids or other sealable metal or plastic containers since they can be thoroughly cleaned inside and out. Cardboard boxes disintegrate in a short time and harbor seeds, animals, etc., which cannot be easily found or removed. In fact, Crowe (2001) examined the AQIS Pest and Disease Interception Database and found 'hitchhikers' intercepted on various commodities during quarantine, including cardboard boxes, Styrofoam ${ }^{\mathrm{TM}}$ boxes, paper, and building materials. Although fumigation is possible, it is better to avoid use of cardboard and similar packaging and fumigate sparingly when necessary, such as for importing paper and building supplies. Wooden packing materials (pallets, crating, boxes) also harbor insects and seeds and should be avoided and only allowed if well constructed (tight fitting seams are required). For wood packaging, inside and outside surfaces must be painted or varnished to provide a smooth, cleanable finish that seals all holes. For those items that cannot fit into sealable containers, ensure they are visually inspected and clean before loaded into containers. All wood, including building materials, must be treated.

3. Food and cooking items need not be fumigated but should be cleaned and frozen, if freezable. Such equipment can only be packed in wooden crates if treated as described above.

Consider:

1. Requiring cargo treatment if significant or persistent non-native species problems are identified.

\section{Other Biosecurity Risk Associated with Vessels/Shipping}

Eldredge and Carlton (2002) found most of the established non-native marine invertebrate species in Hawai $i$ were introduced as a result of hull fouling $(90 \%)$ followed by ballast water. Saverese (2005) found that although ballast water from ships has been considered the primary vector for the transport of aquatic nuisance species, hull fouling is a major concern. Saverese (2005) cites a recent study for North America, which found that 36\% of coastal invasive species in North America could be the result of hull fouling and another $20 \%$ could be the result of ballast water. These statistics indicate the need for preventative measures. A new federal mandatory ballast water management statute directs the Coast Guard, under its duties of vessel inspection in U.S. Coast Guard 33 CFR 151, regarding hull fouling by requiring "Masters, owners, operators, or persons-in-charge of all vessels equipped with ballast water tanks that operate in the waters of the U.S. must rinse anchors and anchor chains when [retrieving] the anchor to remove organisms and sediments at their place of origin" and "remove fouling organisms from hull, piping, and tanks on a regular basis and dispose of any removed substances in accordance with local, State, and Federal regulations." 
Many of the procedures outlined in this statute are required for permitted visits to the Papahānaumokuākea Marine National Monument (U.S. Fish and Wildlife and others, 2008). Likewise, Palmyra Atoll policies related to the prevention of non-native species introductions through any kind of vessel discharge should consider following those adopted by the Department of Land and Natural Resources: Hawai i Administrative Rules Title 13, chapter 76, Hawai`i Administrative Rules (Nonindigenous species) (see included here as appendix 8, Hawai i Department of Land and Natural Resources, Adoption of Chapter 13-76, Hawai i Administrative Rules, "Non-Indigenous Aquatic Species"). In addition, Palmyra Atoll policy should require inspections and if necessary, cleaning of vessels entering Palmyra Atoll waters. Proof of these inspections and in addition Rodent Free Inspections, Tender Vessel Fouling Inspection (if relevant), and inspection of any gear that will be used in the water or on land must meet minimum requirements and shall occur within a designated timeframe (as an example no more than 14 days prior to departure to Palmyra Atoll) prior to arrival. Deratting certificates have recently been replaced by International Health Regulations in 2005 with Ship Sanitation Certificates. The Center for Disease Control has a Vessel Sanitation Program for cruise ships and is currently awaiting further guidance from the World Health Organization regarding inspection of cargo vessels (http://www.cdc.gov/cogh/ihrMaterial/IHRFaq.htm ).

The Papahānaumokuākea Marine National Monument permitting document also includes the following note: "Results of inspections may require cleaning operations such as rodent eradication, hull cleaning, or ballast water maintenance at your own cost before departing for the Monument. If proposed gear or materials are found to be contaminated with alien species you may be required to conduct specific cleaning measures or complete replacement of contaminated items at your own cost before departing for the Monument. Re-inspection may be required."

\section{Biosecurity Risk Associated with Other Vessels/Shipping}

Vessels other than scheduled cargo services regularly sail to Palmyra Atoll including research vessels (such as those used by NOAA), recreationally visiting and distressed vessels. For those vessels entering within $22 \mathrm{~km}$ of Palmyra Atoll coastline, similar biosecurity risks and preventative procedures outlined for the commercial freight shipping services could apply. If vessels containing freight, equipment, other personal effects, or persons are to come ashore, additional protocols should be followed as relevant (see appendix 2, Palmyra Atoll Special Conditions and Rules for Visiting and Departing Palmyra Atoll and Moving Intra-Atoll and appendix 9, Disinfection of Scientific/Recreational Equipment, Dive Gear and Subsistence or Other Fishing Gear for Prevention of Disease and Introduced Species). All pre-planned visits should receive relevant protocols associated with the permitting process.

In the event of a vessel in distress requiring assistance or refuge, decisions will need to be made on a case by case basis.

Require:

1. All protocols be followed as relevant (see appendix 2, Palmyra Atoll Special Conditions and Rules for Visiting and Departing Palmyra Atoll and Moving Intra-Atoll and appendix 9, Disinfection of Scientific/Recreational Equipment, Dive Gear and Subsistence or Other Fishing Gear for Prevention of Disease and Introduced Species).

Consider:

1. If properly trained, TNC staff could be authorized to perform offshore inspections upon vessel arrival. 
Procedures modified from

U.S. Fish and Wildlife Service, National Oceanic and Atmospheric Administration, and Hawai 1 Department of Land and Natural Resources, 2008, Draft Papahānaumokuākea Marine National Monument Draft Management Plan 2008, Papahānaumokuākea Marine National Monument, v. 3, 422 p.

References Cited

Crowe, Bill, 2001, Hitchhikers not on plant material: Exotic Forest Pests Online Symposium: April 1629, 2001, Accessible at: http://www.apsnet.org/online/proceedings/exoticpest/Papers/crowe.htm.

Eldredge, L.G., 2000, Numbers of Hawai ian species, Supplement 5: Bishop Museum Occasional Papers, v. 63, p. 308.

Eldredge, L.G., and Carlton, J.T., 2002, Hawai ian marine bioinvasions: A preliminary assessment: Pacific Science, v. 56, no. 2, p. 211-212.

Saverese, Jason, 2005, Preventing and managing hull fouling: International, Federal, and State Laws and Policies: Proceedings of the 14th Biennial Coastal Zone Conference New Orleans, Louisiana, July 17-21, 2005, 6 p.

U.S. Environmental Protection Agency, 2000, EPA Methyl Bromide Phase Out Web Site: Accessible at http://mbao.org/mbrqa.html.

U.S. Environmental Protection Agency, 2008, EPA Ozone Layer Depletion-Regulatory Programs Methyl Bromide Questions \& Answers. Accessible at http://epa.gov/spdpublc/mbr/qa.html.

Whinam, J., Chilcott, N., and Bergstrom, D.M., 2005, Subantarctic hitchhikers: expeditioners as vectors for the introduction of alien organisms: Biological Conservation, v. 121, p. 201-219. 


\section{Appendix 6. Disinfection Standards for Used Vehicle, Machinery, and Equipment Destined for Palmyra Atoll}

These guidelines were modified from those developed by the Armed Forces Pest Management Board 2004 and the following procedures are recommended for used vehicles destined for Palmyra Atoll. Modifications should be made as necessary depending on the vehicle, machinery, or equipment being delivered to Palmyra Atoll.

Complete the following actions before the vehicle arrives at the final washing location before being loaded onto delivery vessel.

- Sweep, compress air clean and (or) wet/dry vacuum the vehicle cab and all storage and tool compartments.

- Remove the battery; clean the battery and battery box. Reinstall the battery.

- Remove the outside dual wheels and spare tires and place them in the back for later cleaning at the wash rack.

- Remove all payloads, seat cushions, detachable sideboards, canvas sides/tops and any personal gear to be brought ashore, and leave at the mobile staging area for cleaning.

- Carefully check the radiator (may be hot). Handpick or sweep any soil, fungus, vegetation/seeds, insects (arthropods), other animals and their eggs, or other debris.

- Disengage the sides of trucks equipped with collapsible sides. Clean recessed areas, ledges, etc. At the final washing location:

- Vehicles should be exposed to high pressure (recommend minimum $620 \mathrm{kPa}$ ) fresh water or steam (steam may remove valuable protective coatings). Pay particular attention to undercarriages, fender wells, axles, springs, bumpers, wheels and recessed areas. (To prevent corrosion, never use salt water to clean vehicles/supplies/equipment.)

Upon completion of the cleaning procedures:

- Inspect each vehicle thoroughly to ensure that all soil has been removed. Use a flashlight, screwdriver, or putty knife where necessary. The following are common inspection checkpoints:

1. Top access (particular attention must be paid to crevices in all locations). All areas mentioned are primarily on the "dorsal side" of the vehicle and must be accessed from that perspective.

- Floor boards

- Battery box

- All storage/tool compartments

- Motor compartments

- Wheels and tires

- Windshield base

- Front and rear bumper hollows and braces

- Radiator front

- Truck beds

- All other spaces where soil might be found 
2. Bottom access

- Fender wells, front and rear, including access openings for tail light wiring

- Rocker panels

- Frame, fore and aft

- Coil spring wells, front and rear

- Transmission support beam

- Rear suspension A-frame, pivot points and drain holes

- Trailer hitch bolt recess

- Front, side, and rear body lips

- Drive shaft tunnel

- Power take-offs

- Axle brackets

- Fuel tanks, between body and tank

- Transaxle brackets

- Leaf springs

- Air tank braces

- All other spaces where soil might be found

\section{Flow Chart of Typical Operational Washdown}

The order of tasks to be accomplished during a washdown should follow the pattern described below:

Remove detachable parts and mobile loads Top wash

- Clean using a use disinfecting solution when possible.

- Prior to top wash, vacuum or compressed air clean interior of vehicle and remove any trash, soil, fungus, vegetation/seeds, and insects (arthropods) or other animals or their eggs.

- Clean all surfaces.

- Clean compartments.

- Clean engine.

- Clean passenger compartment.

- Clean vehicle bed.

- Clean areas between cab and beds.

- Clean radiator grills.

Wash rack

- Clean all surfaces.

- Clean all wheel wells.

- Clean all ledges.

- Clean engine compartment.

- Clean universal joints.

- Clean support beams.

Wet-Vac

- Remove all trash.

- Vacuum all passenger compartments.

- Vacuum all tool and cargo compartments.

Inspect 
Reassemble

Stage in Cleaning Area

Tips:

- Thoroughly brief personnel.

- Use experienced personnel.

- Use assembly line.

- Complete most cleaning before wash racks if available.

- Have spare equipment.

- Protect hoses.

- Use protective equipment if necessary.

Other factors involving cargo movement:

Equipment (forklifts, tractor-trailers, trucks, and railcars) and materials (pallets, dunnage, and tarpaulins) utilized in the storage and transportation of supplies must be clean of any trash, soil, fungus, vegetation/seeds, and insects (arthropods) or other animals or their eggs.

Modified from

Armed Forces Pest Management Board, 2004, Retrograde washdowns: Cleaning and inspection procedures: Technical Guide No. 31. Washington, DC, Defense Pest Management Information Analysis Center, Accessible at: http://www.afpmb.org/pubs/tims/tg31/tg31.pdf. 


\section{Appendix 7. Disinfection Protocol for Boats and Trailers Destined for Palmyra Atoll}

The following guidelines outline boat cleaning procedures necessary to prevent the spread of aquatic invasive species. The guidelines consist of a nationally accepted set of prevention steps and should be required for all vessels being transported to Palmyra Atoll for onsite use, all vessels being transported off Palmyra Atoll, and all vessels requesting permits for scientific or recreational visits. They are based on procedures developed to help prevent the spread of aquatic invasive species, especially quagga (Dreissena rostriformis bugensis) and zebra mussels (Dreissena polymorpha), on trailered watercraft. Sources include: Chuck O’Neill, Director of the Sea Grant National Aquatic Nuisance Species Clearinghouse, 100th Meridian Initiative, and Protectyourwaters.org, accessed March 13, 2007 (http://www.fs.fed.us/r4/resources/aquatic/tips/boat_inspection_cleaning_procedures.pdf) and are consistent with guidelines developed by the U.S. Coast Guard (2001). Photographs can be found at http://www.fs.fed.us/r4/resources/aquatic/tips/boat_inspection_cleaning_photos.pdf.

\section{The following steps shall be taken for all boats, trailers, equipment or gear that is to be moved between waters (to or from Palmyra Atoll) to avoid transporting invasive species and (or) pathogens:}

- Inspect and remove any trash, soil, fungus, vegetation/seeds, insects (arthropods) or other animals or their eggs from boat, equipment, and gear.

- Drain all water from boat, motor, live well, bilge, transom wells, as well as from equipment and gear, including but not limited to tracked vehicles, barges, silt or turbidity curtain, hoses, sheet pile, and pumps.

- Dispose of any trash, soil, fungus, vegetation/seeds, insects (arthropods) or other animals or their eggs in an appropriate way.

- Disinfect (using methods appropriate to the facilities available at location) boat, trailer equipment, and gear through:

1. Washing with about $100^{\circ} \mathrm{C}$ water (steam clean),

2. Drying thoroughly for 5 days after cleaning with soap and water and (or) high pressure water,

3. Disinfecting with either $200 \mathrm{ppm}$ ( $4 \mathrm{ml}$ per liter) Chlorine for 10 -minute contact time or 1:100 solution ( 10 grams per liter) of Virkon ${ }^{\circledR}$ Aquatic for 20 - to 30 -minute contact time.

*** Note: Virkon ${ }^{\circledR}$ Aquatic is known to be highly effective against many strains of virus, bacteria, and fungi and is recognized as effective against fish pathogens. It has been not registered to kill zebra mussel veligers or invertebrates like spiny water flea. Therefore, if this disinfectant is chosen, it should be used in conjunction with a hot water $\left(>40^{\circ} \mathrm{C}\right)$ application.

Safety Precautions for Disinfectant Use: 
Virkon ${ }^{\circledR}$ Aquatic (Virkon-A) is a disinfectant in the peroxygen (hydrogen peroxide) family available in powder form. It is $99.9 \%$ biodegradable, breaks down to water and oxygen components, and is not corrosive at the working dilution, but disposal considerations should be addressed When using Virkon-A:

1. Receive and be required to read a copy of the Virkon-A Materials Safety Data Sheet (MSDS) for the product.

2. Wear chemical splash goggles.

3. Wear a face shield where the possibility exists for face contact due to splashing or spraying of the material.

4. Wear impervious clothing to prevent contact with skin (gloves, pants, jacket, hood, and boots) or a Tyvek ${ }^{\circledR}$ style full body suit.

*** In addition, those who handle or mix Virkon-A in powder form and prefer to wear a dust mask respirator when handling powder, should comply with the DNR Respiratory Protection Program Handbook MC 9180.5 Voluntary Use requirements.

Bleach:

Chlorine will break down in sunlight and when in contact with organic material. It is corrosive to metal and rubber. Finally, it is toxic to fish at these concentrations so rinse well after disinfection or neutralize with sodium thiosulfate. For neutralizing chlorine, spray sodium thiosulfate in an $800 \mathrm{ppm}$ solution ( 0.8 grams per liter of water) on all surfaces after the disinfection period is over. Rinse with water to remove any remaining sodium thiosulfate.

When using bleach/chlorine:

Follow precautions 2, 3, and 4 (above).

Sources of disinfectants:

- Chlorine - Household bleach (5.25\% chlorine) can be purchased from a grocery or convenience store. HTH is granular chlorine (70\% calcium hypochlorite) and can be purchased from a pool supply company.

- Sodium Thiosulfate - Commonly used to neutralize chlorine and iodine. It should be available at a pool supply company or from a chemical supply company.

- Virkon ${ }^{\circledR}$ Aquatic is available from Western Chemical. It is the same formulation, but without the perfume and dye, and the label addresses specific fish pathogens. Their phone number is 1-800-2835292.

\section{Boats, Trailers, and Live Wells}

Remove organic material from boats, trailers, and live wells. Drain water from live wells, bilges, and pumps. The outside and inside of the boat, trailer, live wells, bilges, and pumps should be sprayed with the disinfection solution and left wet for the appropriate contact time. The inside of the live wells, bilges, and pumps should be made to contact the solution for the appropriate contact time as well. Run pumps so they take in the disinfection solution and make sure that the solution comes in contact with all parts of the pump and hose. The boat, trailer, bilges, live well, and pumps should be rinsed with clean water or water from the next water body after the appropriate contact time. Every effort should be make to keep the disinfection solution and rinse water out of surface waters. 


\section{Motors}

After removing from the water, tip the motor to the down position and start the motor for several seconds or turn motor over several times to dispel water from the cooling system. Alternatively and especially for motors moored in water for several days or more, immerse the lower unit in a bucket of disinfectant and run the motor to ensure contact with all internal parts and allow for the appropriate contact time. Or, rig up a short (1.8-m) piece of garden hose to lower unit muffs. A pail of the disinfectant can be set in the back of the boat and gravity fed to the lower unit to run the disinfectant through the motor. Allow solution to remain in motor for the appropriate contact time. The hose will need to be primed to start the gravity flow because the lower unit does not create enough suction to prime the hose. A non-corrosive (Virkon ${ }^{\circledR}$ Aquatic) is recommended for use to protect the impeller. Rinse with clean water or water from the next water body. 
Appendix 8. Hawai i Department of Land and Natural Resources, Adoption of Chapter 13 -76, Hawai' i Administrative Rules, "Non-Indigenous Aquatic Species"

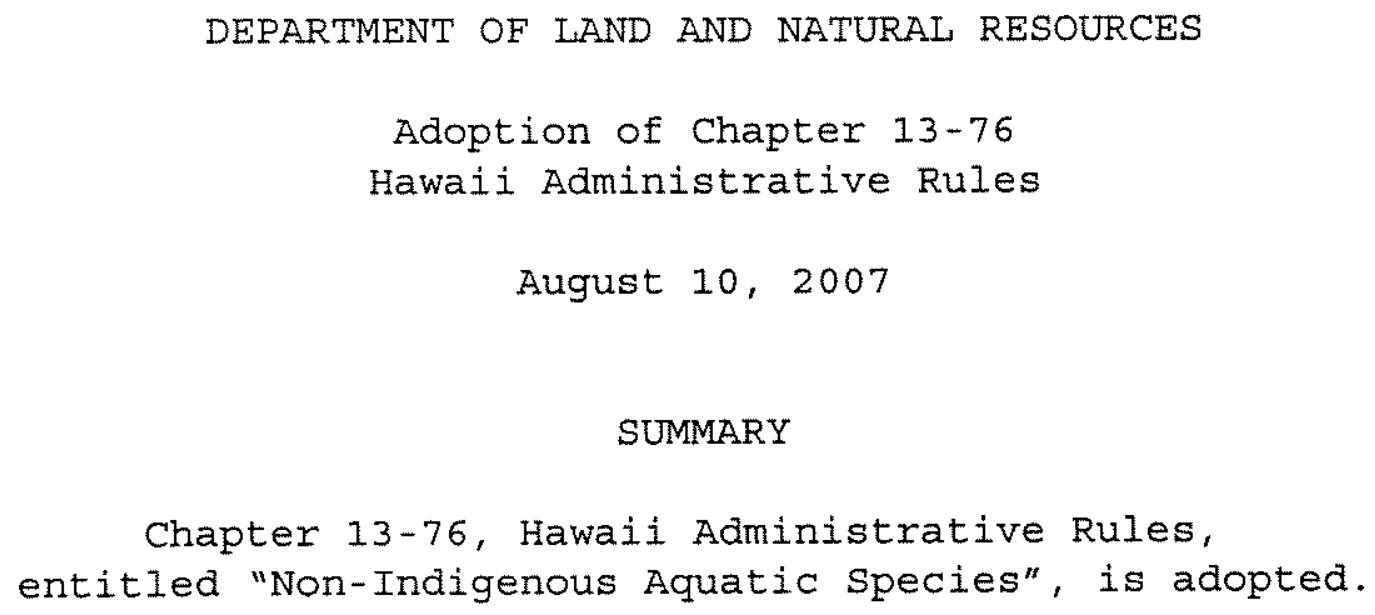




\section{HAWAII ADMINISTRATIVE RULES}

TITLE 13

DEPARTMENT OF LAND AND NATURAL RESOURCES

SUBTITLE 4

FISHERIES

PART IV FISHERIES RESOURCE MANAGEMENT

CHAPTER 76

NON-INDIGENOUS AQUATIC SPECIES

Subchapter 1 General Provisions

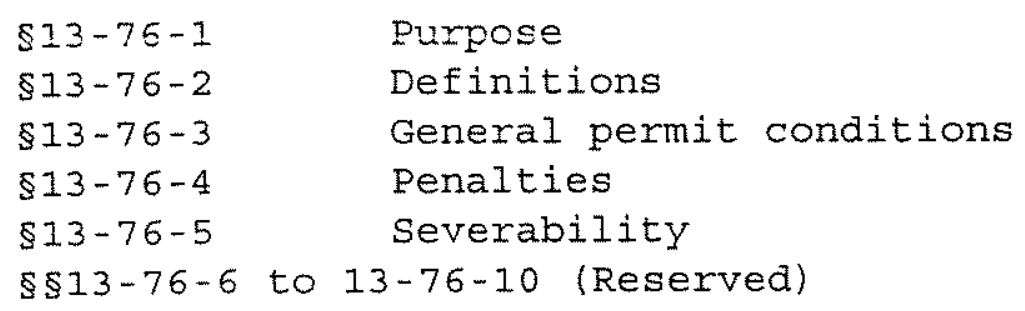

Subchapter 2 Ballast Water Management

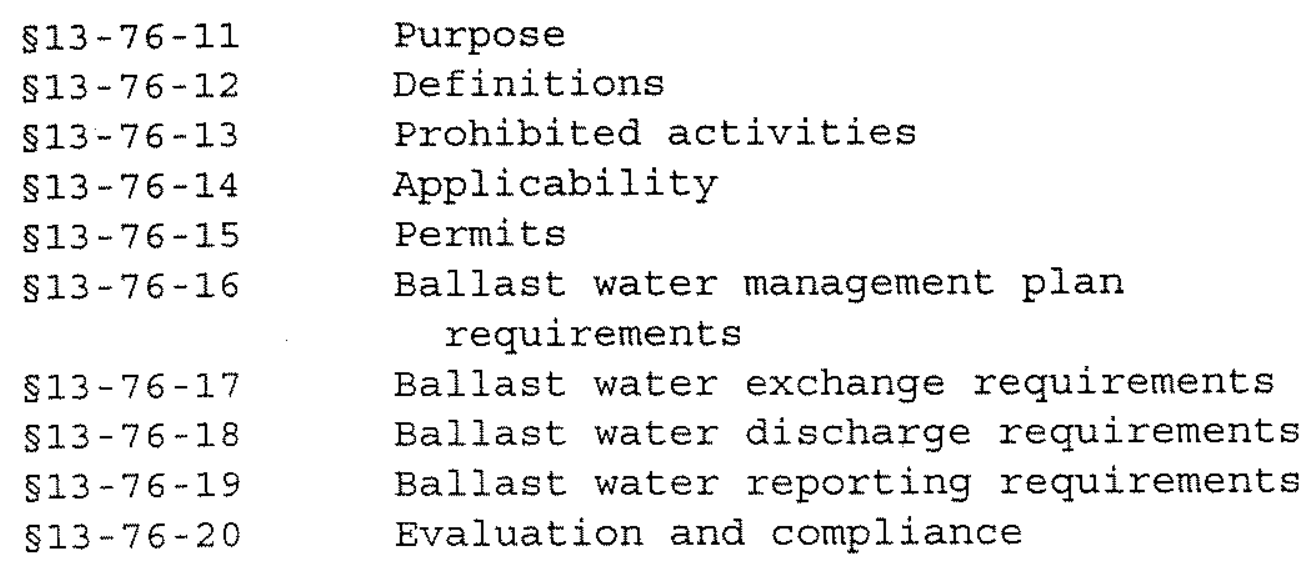


\$13-76-1 Purpose. This chapter governs rules aimed at preventing, to the extent practical, the introduction and spread of non-indigenous aquatic species into state waters. Such non-indigenous aquatic species are potentially harmful to the environment and economy of Hawaii because they may replace or destroy native species and alter their habitats. [Eff OCT 122007 ] (Auth: HRS \$187A-32) (Imp: HRS $\$ 187 A-32$ )

\$13-76-2 Definitions. As used in this chapter unless otherwise provided:

"Board" means the board of land and natural resources.

"Department" means the department of land and natural resources.

"Master" means the person authorized by the vessel operator to be the captain of the vessel.

"Non-indigenous aquatic species" means any marine, brackish water, or freshwater species or other viable biological material, including, but not limited to, eggs, spores, or seeds, that enters or exists in an ecosystem where it was not known to have existed before, is outside its natural or historic range, or may have come to Hawaii by human introduction.

"person" means any individual, corporation, partnership, trust, association, or other private entity, or any officer, employee, agent, department, or instrumentality of the federal government, of any state or political subdivision thereof, or of any foreign government.

"State" means the state of Hawaii.

"State marine waters" means all waters of the state, including the water column and the water surface, extending from the upper reaches of the wash of the waves on shore seaward to the limit of the 
State's police power and management authority, including the United states territorial sea, notwithstanding any law to the contrary.

"USCG" means the United states Coast Guard.

"Vessel operator" means a company that owns, operates or has chartered a vessel. [Eff OCT 122007 ] (Auth: HRS \$187A-32) (Imp: HRS \$187A-32)

\$13-76-3 General permit conditions. (a) The general permit provisions of this section shall be in addition to the more specific provisions of section 13-76-15, and as otherwise provided in this chapter.

(b) The department may require persons to submit an application for a permit issued pursuant to this chapter.

(c) The submission of an application to the department shall not obligate the department to issue a permit or constitute a right or interest on the part of the applicant to have a permit issued.

(d) A permit shall have a limited duration subject to the provisions of this chapter, but such duration shall not exceed one year from the date of issuance. The issuance of a permit shall not constitute a vested right or property interest to receive future or additional permits.

(e) Permits are non-transferable, so that whenever a permittee parts with possession or transfers, in whole or in part, the title to or interest in the vessel identified in the permit to another person by any arrangement, the permit shall immediately expire. The permittee must notify the department prior to and immediately after such transfer has occurred.

(f) The department may impose terms and conditions it deems necessary to carry out the purposes of this chapter, including requiring a report or reports of any activity conducted that may potentially introduce a non-indigenous species to state marine waters by the applicant or permit holder within the state. 
(g) It is unlawful for any person to violate any provision of any permit issued pursuant to this chapter. Failure to comply with any provision of this chapter, or any provision of any permit issued hereunder, shall be cause for termination of said permit.

(h) If the department determines that the protection and conservation of aquatic life in the area requires the cessation of all or certain activities allowed under the permits, upon notification to the permit holders of this determination by any reasonable means, the permits shall automatically expire on a date provided in the notification.

(i) There is no right to a renewal or reissuance of a permit. When reviewing an application for a permit, the department shall consider whether the applicant has previously violated or not complied with any term or condition of a permit and may deny the application on this basis.

(j) The permittee shall have the permit on board the vessel and be able to show the permit upon the demand of any employee, agent, or officer authorized to enforce this chapter. Failure or refusal to show the permit shall be a violation of this chapter and sufficient cause to immediately but temporarily suspend the permit until such time that the board may take action to revoke the permit.

(k) The board may revoke any permit for any violation of the terms and conditions of the permit and a person whose permit was revoked shall not be eligible to apply for another permit until one year from the date of revocation. [Eff DCT I 2ZWU! ] (Auth: HRS $\$ \$ 187 A-5,187 A-32$ ) (Imp: HRS $\$ \$ 187 A-5$, 187A-32)

\$13-76-4 Penalties. A person violating the provisions of this chapter shall be guilty of a petty misdemeanour, as provided under section 187A-13, HRS, subject to administrative penalties as provided under 
section 187A-12.5, HRS, and punished as provided by law. [Eff OCT 122007 ] (Auth: HRS $\$ 187 \mathrm{~A}-12.5$, $187 A-13,187 A-32$ ) (Imp: HRS $\$ \$ 187 A-12.5,187 A-13$ )

\$13-76-5 Severability. The provisions of these rules are declared to be severable, and if any portion or the application thereof to any person or property is held invalid for any reason, the validity or application of the remainder of these rules to othef persons or property shall not be affected. [Eff

OCf 122007 ] (Auth: HRS $\$ 187 \mathrm{~A}-12.5,187 \mathrm{~A}-13$, 187A-32) (Imp: HRS $\$ \$ 187 A-12.5,187 A-13$ )

\section{SUBCHAPTER 2}

\section{BALLAST WATER MANAGEMENT}

\section{\$13-76-11 Purpose. (a) This subchapter} addresses the management and disposition of vessel ballast water as a medium or means for the introduction of aquatic invasive species into state marine waters, such as but not limited to any ocean, estuary, bay, harbor, beach, or coastal area. These rules are intended to act in coordination with federal regulations on ballast water management by 1 ) establishing state laws that will correspond to and complement federal regulations on ballast water to ensure consistency, 2) providing best practices guidelines to improve vessel ballast water management prior to entering state marine waters, 3) adopting a ballast water management program, including a ballast water exchange reporting system, and 4) monitoring compliance with program requirements.

(b) This subchapter identifies: 1) prohibited activities; 2) vessels exempted from ballast water management plan requirements, ballast water reporting requirements, ballast water exchange requirements, and ballast water discharge requirements; 3) which permits are available to qualifying vessels; 4) requirements 
that incoming vessels are subject to regarding ballast water; and 5) State verification of compliance with this subchapter. [Eff OCT 122007 ] (Auth: HRS $\S \S 187 A-5,187 A-32)$ (Imp: HRS $\$ \S 187 A-5,187 A-32$ )

\$13-76-12 Definitions. As used in this subchapter, unless otherwise provided:

"Aquatic invasive species" means a non-indigenous aquatic species, which, if introduced into an ecosystem, may cause harm to Hawail's economy, environment, human health, or public safety and welfare.

"Ballast operations" means the transfer, uptake, and/or discharge of ballast water.

"Ballast tank" means any tank, hold, or part of a vessel used to carry ballast water, whether or not the tank or hold was designed for that purpose.

"Ballast water" means any water, associated sediments, and suspended matter taken on board a vessel to manipulate, control, or maintain trim, draft, stability, or stresses of the vessel, without regard to the manner in which it is carried.

"BWM" means ballast water management as required by federal law 33 CFR Part 151 Subpart D, Mandatory Ballast Water Management Program for U.S. Waters, dated July 28, 2004.

"Coastwise trade" includes the transportation of passengers or merchandise between points embraced within the coastwise laws of the United states.

"Discharge" means to drain or remove part or all of the ballast water off the vessel.

"EEZ" means the United states exclusive economic zone established by Presidential Proclamation No. 5030, dated March 10, 1983, which extends from the baseline of the territorial sea of the United States seaward 200 nautical miles, substantially as defined in federal law 33 CFR 151.2025, dated July 1, 2005.

"Empty/refill exchange" means to pump the ballast tank or tanks out, until empty or as close to empty as the master determines is safe to do so, then refilling 
the tank with mid-ocean waters.

"Exchange" means to replace water in ballast

tanks by using flow through exchange, empty/refill exchange, or other exchange methodology recommended or required by the United States Coast Guard.

"Flow through exchange" means to flush out ballast tanks by pumping in mid-ocean water at the bottom of the tank and continuously overflowing the tank from the top until three full volumes of the ballast water tank capacity have been changed.

"MHI EEZ" means the main Hawaiian islands exclusive economic zone identified as those waters of the EEZ surrounding the main Hawaiian islands east of $161^{\circ}$ West longitude.

"Mid-ocean waters" means waters at least 200 nautical miles from any coast.

"Permanent ballast" means a weight or heavy material added to a vessel to enhance the vessel's stability that is always left on the vessel and not normaliy removed either between or duxing voyages.

"Transfer" means the on-board movement of ballast water from one part of the vessel to another. "Qualifying vessels" means all vessels, United states or foreign flagged, carrying ballast water into state marine waters after operating outside the EEZ. "Sediments" means any material that settles out of ballast water within a vessel.

"Uptake" means to fill part or all of the vessel's ballast tanks with water from outside the vessel.

"Vessel in innocent passage" means a ship engaged in continuous and expeditious surface passage through the territorial sea and archipelagic waters of foreign coastal states in a manner not prejudicial to its peace, good order, or security. Passage includes stopping and anchoring, but only if incidental to ordinary navigation or necessary by rough weather or distress, or for the purpose of rendering assistance to persons, ships, or aircraft in danger or distress. "Voyage" means any transit by a vessel that originates from a port or place outside of the EEZ 
surrounding the state of Hawaii and destined for a port or place in Hawaii. [Eff OCT 122007 ] (Auth: HRS $\$ 187 A-32$ ) (Imp: HRS $\$ 187 A-32$ )

\$13-76-13 Prohibited activities. (a) Unless exempted under the provisions of section 13-76-14, by permit issued pursuant to section 13-76-15, or as may be otherwise provided by law, it is unlawful for the master of a qualifying vessel:

(1) To fail to have or fail to follow a ballast water management plan, as required under section 13-76-16;

(2) To exchange ballast water contrary to the provisions of section 13-76-17;

(3) To discharge, or allow the discharge of, ballast water in state marine waters in violation of section 13-76-18;

(4) To fail to submit a ballast water report form, as required in section 13-76-19; and

(5) To violate any provision in this subchapter.

(b) It is unlawful for the master to prevent, hinder, or otherwise interfere with the department's or USCG's evaluation of the vessel's compliance with the provisions of this subchapter. The evaluation may be conducted in accordance with section 13-76-20 and as may be otherwise provided in this subchapter. [Eff OCT 122007 ] (Auth: HRS $\$ \$ 187 \mathrm{~A}-5,187 \mathrm{~A}-32$ ) (Imp: HRS $\$ \$ 187 A-5, \quad 187 A-32)$

\$13-76-14 Applicability. (a) The ballast water management plan requirements of section 13-76-16 shall apply to qualifying vessels.

(b) The ballast water reporting requirements of section 13-76-19 shall apply to qualifying vessels, except for the following:

(1) Crude oil tankers engaged in coastwise trade. This exemption applies only to vessels carrying unrefined crude oil product from one U.S. place to another, including 
Hawaii;

(2) Any vessel of the United states Department of Defense or USCG, subject to the requirements of Section 1103 of the National Invasive Species Act of 1996, or any vessel of the armed forces, as defined in section 1322 (a) (14) of Title 33 of the United states Code that is subject to the "Uniform National Discharge Standards for Vessels of the Armed Forces" pursuant to section $1322(n)$ of Title 33 of the United States Code;

(3) Any vessel that operates exclusively within the MHI EEZ;

(4) Any vessel that operates outside of the EEZ, but conducts all ballast operations exclusively in the MHI EEZ, regardless of the number of voyages the vessel makes; and

(5) Any vessel in innocent passage or having entered state marine waters due to circumstances beyond its control; provided that the vessel does not discharge ballast water into state marine waters, or into waters that may impact state marine waters, unless the vessel meets the requirements of section 13-76-18;

(c) The ballast water exchange requirements of section 13-76-17 shall apply to qualifying vessels that conduct ballast water exchanges; except for vessels exempted under subsection 13-76-14(b)

$(1),(2),(3),(5)$ and the following:

(1) Any vessel equipped with a functioning treatment system designed to kill all living aquatic organisms in the ballast water; provided that USCG or other approving authority has determined that the system is designed to be at least as effective as ballast water exchange at reducing the risk of transfer of aquatic invasive species in ballast water and the treatment system is properly functioning as designed; and 
(2) Any vessel, to the extent that it is equipped with permanent, freshwater, or treated ballast, as specified in section 1376-14 (c) (1) above or will not discharge ballast water in state marine waters.

(d) The ballast water discharge requirements of section 13-76-18 shall apply to qualifying vessels that either will discharge or have discharged ballast water into state marine waters; except for vessels exempted under subsections 13-76-14(b) (2) and (3), and $13-76-14(\mathrm{c})(1)$ and (2).

(e) The master, or vessel operator when there is no master, shall be responsible for complying with the provisions of this subchapter, unless otherwise provided. Nothing in this subchapter shall relieve the master of the responsibility to ensure the safety and stability of the vessel or the safety of the crew and passengers, or any other responsibility. [Eff

OCT 122007 ] (Auth: HRS \$187A-32) (Imp: HRS $\$ 187 \mathrm{~A}$ 32)

\$13-76-15 Permits. (a) The department may issue permits to vessel operators, exempting qualifying vessels from the provisions of this subchapter, subject to the provisions of section 1376-3 and the following conditions:

(1) Receipt of a completed application, on a form provided by the department, and any other information the department may require; and

(2) Approval by the department, after an assessment of the appropriateness of the application based on:

(A) Safety of the crew or its passengers, USCG approved ballast water treatment system, protection of property, vessel integrity or other factors the department considers relevant to the intent and purpose of this subchapter; and 
(B) All applicable state and federal law.

(b) The permit exemptions are limited to the provisions of this subchapter and do not exempt the master from other state laws or any federal laws. [Eff OCT 122007 ] (Auth: HRS $\$ \$ 187 \mathrm{~A}-5,187 \mathrm{~A}-32$ ) (Imp: HRS $\$ \$ 187 \mathrm{~A}-5,187 \mathrm{~A}-32$ )

\section{\$13-76-16 Ballast water management plan} requirements. Vessels in compliance with BWM requirements for a ballast water management plan, shall be deemed to also be in compliance with this section. It is unlawful for any master to violate BWM requirements for a ballast water management plan. [EfE OC 122007 ] (Auth: HRS $\$ 187 \mathrm{~A}-32$ ) (Imp: HRS $\S 187 \mathrm{~A}-32)$

\$13-76-17 Ballast water exchange requirements. (a) Qualifying vessels that require ballast water exchanges shall conduct such exchanges in mid-ocean waters. Uniess exempted by section 13-76-14(c), or as may be otherwise provided by law, it is unlawful for a master to conduct a ballast water exchange within state marine waters while holding ballast water obtained from an area less than 200 nautical miles from any coast.

(b) All such exchanges shall be by flow through exchange, empty/refill exchange, or other exchange methodology recommended or required by the USCG or other approving authority.

(c) The master is responsible for the safety of the vessel, its crew, and its passengers and is not required to conduct a ballast water management practice, including exchange, if the master determines that the practice would threaten the safety of the vessel, its crew, or its passengers because of adverse weather, vessel design limitations, equipment failure, or any other extraordinary conditions. Should the master make such a determination, the master shall 
take all feasible measures, based on the best available technologies economically achievable, that do not compromise the safety of the vessel, its crew, and its passengers, to minimize the discharge of ballast water containing non-indigenous aquatic species into state marine waters or waters that may impact state marine waters. Such discharge shall be subject to the provisions of section 13-76-18.

(d) Nothing in this subchapter relieves the master of the responsibility for ensuring the safety and stability of the vessel or the safety of the crew and passengers, or any other responsibility. [Eff 32)

OCT 122007 ] (Auth: HRS $\$ 187 \mathrm{~A}-32$ ) (Imp: HRS $\$ 187 \mathrm{~A}-$

\$13-76-18 Ballast water discharge requirements. (a) To the extent practical, the master of any qualifying vessel that has not conducted a mid-ocean waters ballast water exchange, and is subject to the provisions of subsection 13-76-14(d), shall not discharge ballast water into state marine waters.

(b) The master shall report to the department, pursuant to section 13-76-19, when a mid-ocean waters ballast water exchange was not done and a ballast water discharge into state marine waters is necessary.

(c) Unless exempted by subsections 13-76-14 (c) or 13-76-14(e) of this section, prior to any ballast water discharge into the EEZ or state marine waters, the master shall obtain approval from the department to discharge ballast water. Upon approval, the master shall then implement all feasible measures to minimize the discharge of ballast water.

(d) This subchapter does not authorize the discharge of oil, noxious liquid substances, or any other pollutant in a manner prohibited by state, federal or international laws or regulations. Ballast water carried in any tank containing a residue of oil, noxious liquid substances, or any other pollutant shall be discharged in accordance with the applicable requirements. 
(e) The master shall be exempted from the provisions of subsections 13-76-18(a) and 13-76-18(c), if the master determines that such ballast water discharge is necessary to ensure the safety and stability of the vessel or the safety of the crew and passengers, because of adverse weather, vessel design Iimitations, equipment failure, or any other extraordinary conditions. [Eff OOT 122007 ] (Auth: HRS $\$ 187 A-32$ ) (Imp: HRS $\$ 187 A-32$ )

\$13-76-19 Ballast water reporting requirements. (a) Unless exempted in subsection 13-76-14(b), for all qualifying vessels, the master shall:

(1) Fully and accurately fill out the USCG ballast water report form;

(2) Submit the form by fax, electronic mail, or as otherwise provided to the department no later than twenty-four (24) hours prior to vessel arrival into state marine waters;

(3) Submit an amended form to the department before the vessel departs state marine waters, should there be a change in any of the information submitted in accordance with this section; and

(4) Maintain on board the vessel records that include all of the information provided on the form for at least two years.

(b) Submission of this form or an amended form to the department does not relieve the master of the responsibility to report to the USCG, if the USCG requires such report or amended form. [Eff

\$187A-32) 12007 ) (Auth: HRS \$187A-32) (Imp: HRS

\$13-76-20 Evaluation and compliance. (a) In order to evaluate the compliance rate of qualifying vessels with the provisions of this subchapter, the department, in coordination with the USCG, may: 
$\$ 13-76-20$

(1) Take samples of ballast water and sediment, examine documents, and make other

appropriate inquiries;

(2) Compile the information obtained from submitted reports and use the information in conjunction with existing information relating to the number of vessel arrivals; and

(3) Take other actions necessary for the purposes of this subchapter.

(b) The master shall make available to the department, upon the department's request, the records required by section 13-76-19 and other relevant information. [Eff OCT 122007 ] (Auth: HRS $\$ 187 \mathrm{~A}-$ 32) (Imp: HRS $\$ 187 A-32$ ) 


\section{DEPARTMENT OF LAND AND NATURAL RESOURCES}

Chapter 13-76, Hawaii Administrative Rules, on the Summary Page dated August 10, 2007, was adopted on August 10, 2007, following a public hearing held on June 28, 2007, after public notice was given in the Honolulu star-Bulletin on May 20, 2007.

The adoption of chapter 13-76 shall take effect ten days after filing with the office of the Lieutenant Governor.

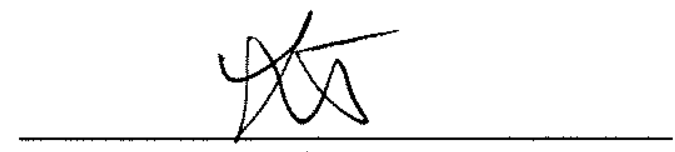

Laura $\mathrm{H}$. Thielen

Interim Chairperson

Board of Land and Natural

Resources

APPROVED :

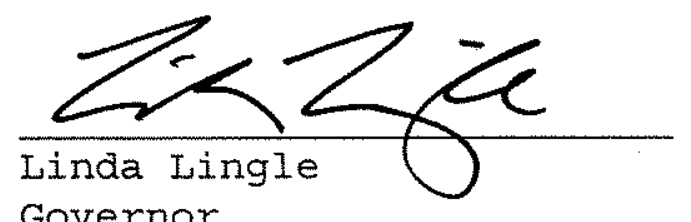

Governor

state of Hawaii

Dated: $\quad$ OCT -12007

APPROVED AS TO FORM:

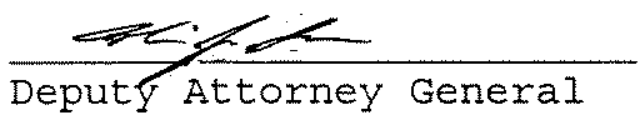

Filed

$76-15$

75 


\section{Appendix 9. Disinfection of Scientific/Recreational Equipment, Dive Gear, and Subsistence or Other Fishing Gear for Prevention of Disease and Introduced Species}

These rules are intended to be distributed to visitors before arrival at Palmyra Atoll and should be understood, implemented, and enforced by all TNC staff. TNC staff should review the guidelines with each visitor upon arrival, and the rules should be posted visibly in appropriate locations (e.g., galley, snorkel tent, kayak tent, dive building, dock, and wet/dry laboratory).

\section{Scientific and Other Equipment Including Dive and Fishing Gear}

Equipment and gear are treated according to three levels that correspond to the potential for the spread of disease and (or) introduced species. General points applicable to all levels (Sections A-C) and acceptable disinfection solutions are listed in Section D.

Useful definitions:

- "Non-porous equipment" (e.g., forceps, chisels, fishing gaff, hooks, swivels)

- "Porous equipment and dive gear" (e.g., gloves, nylon mesh bags, multi-strand 'braided' fishing line)

A. Level One: Equipment/gear in direct contact with diseased coral tissue or other diseased organisms

- Equipment: includes, but is not limited to, gloves, chisels, forceps, drill bits, shears, clippers, and spear tips.

- Multiple sets of equipment: Use a disinfected set of equipment for known diseased coral colonies or other organisms and another disinfected set of equipment for non-diseased coral colonies at each dive site.

1. Use a disinfected set of equipment at each dive site.

2. Inspect all equipment and remove any organic matter.

3. Disinfect equipment by soaking for a minimum of 10 minutes in an acceptable disinfection solution (see acceptable disinfection solutions listed below).

Non-porous equipment: Use wipes in which the active ingredient is quaternary ammonium chloride compounds (QACs) (e.g., Clorox ${ }^{\circledR}$ or Lysol ${ }^{\circledR}$ wipes) to remove organic matter. Follow wiping by soaking for a minimum of 10 minutes in a disinfectant solution.

Porous equipment: Manually remove any organic matter, and soak for a minimum of 10 minutes in an acceptable disinfectant solution.

1. Secure all samples: Seal all samples in bags or jars under water and place sample bags and jars in secure holding container. 
B. Level Two: Benthic equipment not used to sample diseased coral tissue or other diseased organisms

- Benthic equipment: includes equipment that may contact the benthos, such as reels, tape measures, goodie bags, transect lines, etc.

1. Disinfect equipment between sites: Use a disinfected set of equipment at each dive site.

2. Inspect all equipment and remove any organic matter after use.

3. Disinfect equipment by soaking for a minimum of 10 minutes in a disinfection solution (see acceptable disinfection solutions listed below).

Non-porous equipment must be wiped and (or) soaked. If wiping, use wipes in which the active ingredient is QACs (e.g., Clorox ${ }^{\circledR}$ or Lysol ${ }^{\circledR}$ wipes). If soaking, soak for a minimum of 10 minutes in an acceptable disinfectant solution.

Porous equipment must be soaked for a minimum of 10 minutes in an acceptable disinfectant solution.

C. Third Level: All equipment, including dive and fishing gear used at Palmyra Atoll

- Includes dive gear and associated equipment, including fishing gear, means any items entering the water including, but not limited to wetsuit, mask, fins, snorkel, buoyancy compensator, regulator, weight belt, booties, fishing lines, nets, hooks, lures, fishing gaffes, cameras, etc.

1. Disinfect gear/equipment daily (if used).

2. Inspect all dive gear and remove any organic matter.

3. Disinfect by submerging for a minimum of 10 minutes in an acceptable disinfection solution, followed by a thorough fresh water rinse, and hanging to dry.

Non-porous equipment must be wiped and (or) soaked. If wiping, use wipes in which the active ingredient is QACs (e.g., Clorox ${ }^{\circledR}$ or Lysol ${ }^{\circledR}$ wipes). If soaking, soak for a minimum of 10 minutes in an acceptable disinfectant solution.

Porous equipment must be soaked for a minimum of 10 minutes in an acceptable disinfectant solution.

D. General Points applicable to all three levels

1. Disinfect any equipment and gear at least daily if used. Only disinfected equipment and gear may be transported between Palmyra Atoll and other destinations, such as the main Hawai ian Islands.

2. Dispose of organic matter and used disinfecting solution according to the field station/ship's solid waste disposal or other approved secure holding system. Acceptable Disinfection Solutions:

1. $3 \%$ dilution of commercial bleach (e.g., Clorox ${ }^{\circledR}$ or other $5-6 \%$ sodium hypochlorite product) in fresh water.

2. The manufacturer's recommended disinfection strength dilution of quaternary ammonium compounds (QAC) in "soft" (low concentration of calcium or magnesium ions) fresh water. An example of an acceptable QAC solution is Lysol@ All Purpose Cleaner in a $6.6 \%$ Lysol ${ }^{\circledR}$ : water dilution. Other products should be evaluated according to the Material Safety Data Sheet. 


\section{Cleaning Local Transport Vessels Used within the Lagoon, Reef Flats or Backreef-Resident or Visiting (including Kayaks, Lagoon Boats, Safety Boats, Tender Vessels, etc.)}

Briefly, these procedures include carefully inspecting kayaks, lagoon boats, safety boats or any other vessels (resident or visiting) used within the lagoon, reef flats, or back reef, as well as their associated equipment (life vests, anchors and lines, engine, seats, cushions, storage compartments, and stored equipment, etc.). During inspection, all visible 'contamination' should be removed and if necessary, equipment should be hosed down before departing the Cooper/Menge/Strawn Islet complex when traveling between islets.

1. Prior to departure from dock or moving between locations (or from visiting vessel), inspect vessels, associated equipment (life vests, anchors and lines, engine, seats, cushions, storage compartments, and stored equipment), and any other equipment aboard (e.g., backpacks, ice chests, shoes, etc.). Remove appropriately any potential sources of contamination, including algal fragments, soil, plant material and seeds, insects, lizards, and rodents or other animals and their eggs or cysts.

2. At least daily (if vessel is used) and after each use upon return to dock/kayak tent, inspect for and remove any algal fragments or other organisms (dispose of organic matter and used solution according to the field station/ship's solid waste disposal or other approved secure holding system).

3. Rinse vessel's internal and external surfaces with fresh water between uses, including during transits between Palmyra Atoll and other destinations. Allow vessel to dry before redeployment between Palmyra Atoll and other destinations.

\section{Disinfection of Field Station Dry/Wet Laboratory}

1. At least daily (if laboratory is used), disinfect entire laboratory (areas used inside or outside of building). This procedure may include disinfecting sink, countertops, walls, doors, floors, hood, and anything else that has been in contact with the terrestrial or marine environment outside of Cooper Islet prior to disinfection.

2. Dispose of all materials generated during cleaning according to the field station/ship's solid disposal or other secure holding system.

3. Any visiting research vessel laboratory must be cleaned between destinations, including during transits to or from Palmyra Atoll.

Acceptable Disinfection Solutions and Wipes:

1. $3 \%$ dilution of commercial bleach (e.g., Clorox ${ }^{\circledR}$ or other $5-6 \%$ sodium hypochlorite product) in fresh water.

2. The manufacturer's recommended disinfection strength dilution of quaternary ammonium compounds (QAC) in "soft" (low concentration of calcium or magnesium ions) fresh water. An example of an acceptable QAC solution is Lysol® All Purpose Cleaner in a 6.6\% Lysol®:water dilution. Commercially available wipes containing QACs (e.g. Clorox ${ }^{\circledR}$, Lysol ${ }^{\circledR}$ ) also are acceptable.

3. $70-80 \%$ ethanol.

Modified from

U.S. Fish and Wildlife Service, National Oceanic and Atmospheric Administration, and Hawai i Department of Land and Natural Resources, 2008, Draft Papahānaumokuākea Marine National Monument Draft Management Plan 2008: Papahānaumokuākea Marine National Monument, v. 3, 422 p. 


\section{Appendix 10. Draft of Communications Strategy Components for Awareness of Non-Native/Invasive Species at Palmyra Atoll}

The Biosecurity Plan for Palmyra Atoll suggests education as a priority measure in effectively managing non-native species on the atoll.

Purpose

This communications strategy outlines education components that will be used to prevent nonnative species from arriving at and spreading throughout Palmyra Atoll.

Message

The key message is that non-native species introductions are detrimental to the native ecosystems and prevention is the most cost effective and efficient strategy for controlling non-native species.

The Audience

The audience for this strategy includes all groups involved with moving people and freight to and from Palmyra Atoll, as well as all staff and visitors to Palmyra Atoll.

The main groups in this "audience" are:

- $\quad$ Shipping operators

- Air operators

- Freight companies and suppliers

- Regular visitors (industry, government agencies, recreational visitors - e.g., TNC, USFWS, Palmyra Atoll Research Consortium (PARC), visiting vessel passengers)

Method

- Printed products (e.g., a manual, instructions with permit applications and (or) travel requirements, and posters or signs for distribution on Palmyra Atoll)

- Web page/links online, including instructional videos

- Regular communication

- Education and training of staff and commercial operators

- Education of visitors 
This page left intentionally blank 
Publishing support provided by the U.S. Geological Survey

Publishing Network, Sacramento and Tacoma Publishing

Service Centers

For more information concerning the research in this report, contact the

Director, Western Ecological Research Center,

U.S. Geological Survey

3020 State University Drive East

Sacramento, California 95819

http://www.werc.usgs.gov 
